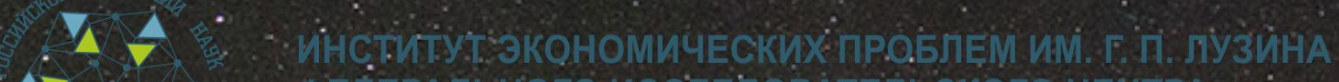

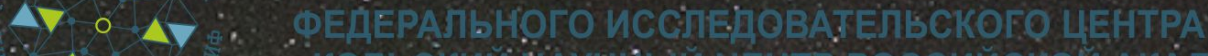

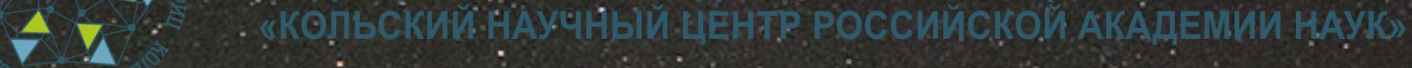

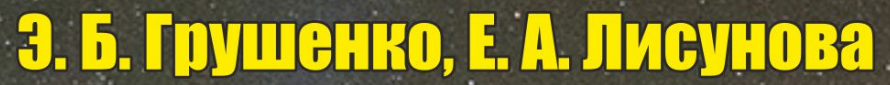

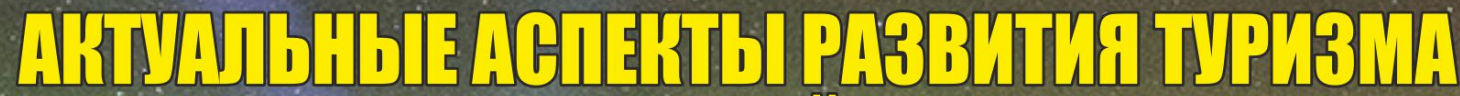

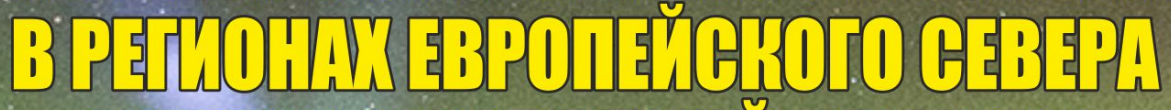

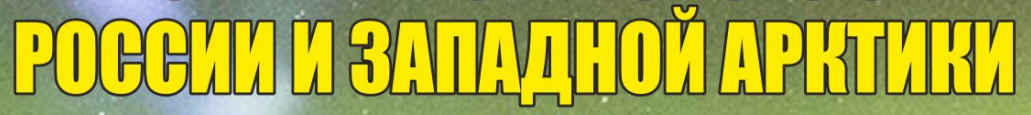


МИНИСТЕРСТВО НАУКИ И ВЫСШЕГО ОБРАЗОВАНИЯ РОССИЙСКОЙ ФЕДЕРАЦИИ

ФЕДЕРАЛЬНЫЙ ИССЛЕДОВАТЕЛЬСКИЙ ЦЕНТР «КОЛЬСКИЙ НАУЧНЫЙ ЦЕНТР РОССИЙСКОЙ АКАДЕМИИ НАУК»

ИНСТИТУТ ЭКОНОМИЧЕСКИХ ПРОБЛЕМ ИМ. Г. П. ЛУЗИНА

Э. Б. Грушенко, Е. А. Лисунова

\section{АКТУАЛЬНЫЕ АСПЕКТЫ РАЗВИТИЯ ТУРИЗМА В РЕГИОНАХ ЕВРОПЕЙСКОГО СЕВЕРА РОССИИ И ЗАПАДНОЙ АРКТИКИ}

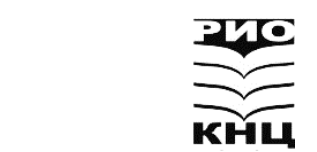

Издательство ФИЦ КНЦ РАН

2021 
УДК 338.48

doi:10.37614/978.5.91137.451.8

ББК 65

Г91

Печатается по решению Редакционно-издательского совета Федерального исследовательского центра «Кольский научный центр Российской академии наук»

\section{Грушенко, Э. Б.}

Г91 Актуальные аспекты развития туризма в регионах Европейского Севера России и Западной Арктики / Э. Б. Грушенко, Е. А. Лисунова. Апатиты: Издательство ФИЦ КНЦ РАН, 2021. — 110 с. : ил.

\section{ISBN 978-5-91137-451-8}

Рассматриваются актуальные проблемы развития туристской отрасли на Европейском Севере России (Мурманская, Архангельская, Вологодская области, Республика Карелия) и на высокоширотных территориях Западной Арктики.

Даны практические предложения и рекомендации, сформулированы первоочередные задачи по решению основных социально-экономических проблем использования туристско-рекреационного потенциала, развития въездного и внутреннего туризма в целях устойчивого развития регионов, уникальных территорий и центров туризма. Результаты могут быть использованы для совершенствования законодательных и нормативных актов туристской отрасли, для повышения ее конкурентоспособности на Севере России.

Издание представляет интерес для профессиональных работников туристской сферы, органов власти, научных работников, туристов, преподавателей, аспирантов и студентов.

УДК 338.48

ББК 65

Научно-популярное издание

Редактор Е. Н. Еремеева

Технический редактор В. Ю. Жиганов

Подписано в печать 24.11.2021. Формат бумаги 70×108 1/16.

Усл. печ. л. 9,62. Заказ № 24. Тираж 500 экз.

ISBN 978-5-91137-451-8
(C) Э. Б. Грушенко, Е. А. Лисунова, 2021

(C) Институт экономических проблем им. Г. П. Лузина, 2021

(C) ФИЦ «Кольский научный центр Российской академии наук», 2021 


\section{ОГЛАВЛЕНИЕ}

ВВЕДЕНИЕ ........................................................................... 4

1. РАЗВИТИЕ СЕВЕРНОГО И АРКТИЧЕСКОГО ТУРИЗМА

В УСЛОВИЯХ ПАНДЕМИИ.............................................................. 6

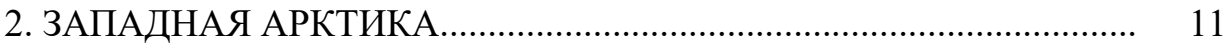

2.1. Евро-Арктическая зона России..................................................... 11

2.2. Высокоширотные архипелаги Западной Арктики....................... 15

2.2.1. Архипелаг Шпицберген................................................... 15

2.2.2. Национальный парк «Русская Арктика».............................. 17

3. МУРМАНСКАЯ ОБЛАСТЬ.................................................... 22

3.1. Развитие экологического туризма на основе создания экологических троп и пешеходных маршрутов на Кольском Севере 32

3.2. Териберка.......................................................................... 39

4. ЕВРОПЕЙСКИЙ СЕВЕР РОССИИ (РУССКИЙ СЕВЕР).................. 44

4.1. Туристский потенциал, основные проблемы, виды туризма и туристские маршруты.................................................... 44

4.2. Республика Карелия........................................................ 50

5. РЕГИОНЫ РУССКОГО СЕВЕРА.................................................. 54

5.1. Архангельская область........................................................... 54

5.1.1. Соловецкие острова.................................................. 59

5.2. Вологодская область............................................................. 64

5.2.1. Белозерск....................................................................... 68

5.2.2. Великий Устюг............................................................. 72

5.2.3. Тотьма......................................................................... 75

6. ИСТОРИЧЕСКИЕ ПОСЕЛЕНИЯ ЕВРОПЕЙСКОГО СЕВЕРА

РОССИИ. ПРОБЛЕМЫ ТУРИСТСКОГО ОСВОЕНИЯ

КУЛЬТУРНО-ИСТОРИЧЕСКОГО НАСЛЕДИЯ УНИКАЛЬНЫХ ТЕРРИТОРИЙ.

6.1. Исторические города........................................................... 83

6.2. Самые красивые деревни России - на Русском Севере.............. 90

6.3. Проблемы сохранения историко-культурного наследия............. 96

6.3.1. Отечественный опыт развития сельского туризма в селе:

Вятское как способ возрождения и сохранения

культурно-исторического наследия................................... 100

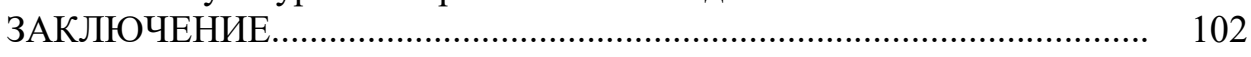

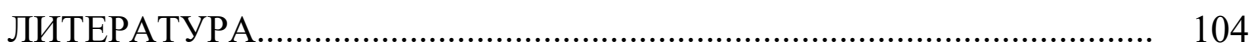




\section{ВВЕДЕНИЕ}

Туризм является одной из крупнейших, высокодоходных и наиболее динамичных отраслей мировой экономики. Как современный сектор экономики он давно вышел за национальные рамки и играет большую роль во взаимодействии и взаимообогащении культур. Туристская индустрия, обладающая мультипликативным эффектом, помогает диверсифицировать экономику, улучшает качество жизни населения, открывает возможности генерирования доходов и новых рабочих мест.

Европейский Север России занимает одно из самых выгодных положений с точки зрения развития туризма благодаря наличию природнорекреационных условий и крупнейших объектов культурного наследия. В его состав входят республики Карелия и Коми, Архангельская область c Ненецким автономным округом, Вологодская и Мурманская области. В советский период Европейский Север назывался Северным экономическим районом. В настоящий период наряду с бывшим Северо-Западным экономическим районом он входит в состав Северо-Западного федерального округа (СЗФО).

Европейский Север открывает широкие перспективы для развития водного, круизного, культурно-познавательного, экологического, делового, событийного, сельского, паломнического, спортивного и других видов туризма. Это памятник мировой культуры, здесь представлена самобытность различных народов и этнографических групп (саамов, поморов, ненцев, коми, карелов, вепсов, финнов, русских), что предопределяет широкие возможности для развития этнографического туризма.

Другое название Европейского Севера - Русский Север - скорее, историко-культурное понятие, чем географическое или административное название.

В последние годы сюда устремляются туристские потоки из России и зарубежья, чему способствуют неповторимое богатство туристских ресурсов, сохранившиеся традиционные виды природопользования, народных промыслов и ремесел, особое географическое положение Европейского Севера как приарктического и приморского региона.

Россия обладает большими инфраструктурными и природными возможностями для туристического освоения Европейского Севера с учетом важности сохранения уникальной экосистемы региона и уклада жизни коренных малочисленных народов Севера. Туризм вносит вклад в развитие территорий и местных сообществ Арктики и Севера: стимулирует предпринимательскую деятельность, создание новых рабочих мест и объектов социальной инфраструктуры, популяризует культурное и природное наследие.

В 2013 г. в издательстве Кольского научного центра РАН вышла монография Э. Б. Грушенко и А. М. Васильева «Туризм на Европейском Севере России и в Западной Арктике». Работа по исследованию актуальных аспектов современного состояния, проблем и перспектив развития туризма в регионах Западной Арктики и Русского Севера была продолжена в 2014-2020 гг., в предлагаемой книге отражены ее результаты.

Объектом исследования является туристская отрасль в регионах Русского Севера и Западной Арктики. Цель работы - анализ современного 
состояния, основных проблем и перспектив развития туризма в рассматриваемых регионах.

Исследованы актуальные вопросы устойчивого развития туристской отрасли на основе изучения проблем современного состояния и перспектив развития туризма в регионах и центрах туризма Русского Севера и Западной Арктики. Особое внимание уделено развитию арктического, экологического, этнографического, культурно-познавательного и сельского туризма. Даны практические предложения и рекомендации по развитию въездного и внутреннего туризма в этих регионах.

Научная новизна состоит в том, что рассмотрены новые туристические направления, тренды и виды туризма, а также дан обзор актуальной ситуации в туристической сфере на основе современных интернет-источников. Предполагаемая роль туристского сектора в сохранении культурного и природного наследия арктических и северных территорий позволяет рассматривать туризм в качестве инновации, сформированной в среде региональных и секторальных инновационных систем самих территорий. Показано, что в 2020 г. на развитие туристской отрасли существенное влияние оказала пандемия COVID-19. Сезон 2020 г. в плане международного и трансграничного туризма оказался убыточным, и туриндустрия регионов вынужденно переориентировалась на внутренний рынок.

В Западной Арктике основное внимание уделено развитию туризма на высокоширотном архипелаге Шпицберген и национальному парку «Русская Арктика». Проведен подробный анализ развития сферы туризма в Мурманской области, в частности в Териберке. Показано эффективное развитие экологического туризма в регионе, описываются оборудованные экологические тропы Мурманской области.

На Русском Севере основное внимание уделено развитию туризма в исторических городах и сельских поселениях. Проанализированы проблемы сохранения и возрождения историко-культурного наследия как фактора устойчивого развития туризма. Работа дополнена фотоиллюстрациями, сделанными Э. Б. Грушенко во время поездок по Русскому Северу.

Проведен анализ перспективных туристских инвестиционных проектов и маршрутов в регионах Европейского Севера. Обоснованы мероприятия по стимулированию повышения конкурентоспособности и социальноэкономической эффективности развития туристской отрасли. Выявлены стратегические направления и задачи, реализация которых государственными органами и туристскими компаниями, занимающимися освоением туристскорекреационных ресурсов, позволит сохранить конкурентные преимущества России в северных и арктических регионах.

Разработанные рекомендации и предложения могут быть использованы для подготовки Стратегии развития арктического туризма до 2030 г. и для корректировки региональных туристских программ Русского Севера. 


\section{1. РАЗВИТИЕ СЕВЕРНОГО И АРКТИЧЕСКОГО ТУРИЗМА В УСЛОВИЯХ ПАНДЕМИИ}

В первой половине 2020 г. существенное влияние на развитие туристской отрасли оказала пандемия COVID-19, охватившая практически все страны мира. На Европейском Севере, как и в целом во всех регионах мира и России, в течение нескольких месяцев наблюдался масштабный коллапс туристской сферы. Туристский поток сократился практически до нуля, закрылись музеи, объекты показа, не работали объекты коллективного размещения и курорты. Туристская индустрия и сфера гостеприимства понесла колоссальные убытки. До улучшения эпидемиологической ситуации была закрыта граница России, ограничено передвижение граждан как внутри регионов, так и между ними.

Самые жесткие ограничения были введены в Республике Карелия, Мурманской и Вологодской областях. В некоторых регионах были закрыты целые города, не работал общественный транспорт (Карелия), для въезда в Вологодский регион требовался электронный пропуск. Наиболее сложная эпидемиологическая обстановка сложилась в Мурманской области, в частности, в Мурманске количество заболевших на душу населения выросло до московского уровня [1]. Наименьшее количество инфицированных было в Республике Карелия и Вологодской области, что позволило уже к середине июля снять практически все ограничения для туристской отрасли и въезда туристов [1, 2]. Летний туристический сезон 2020 г. в плане международного и трансграничного туризма был сорван, и туриндустрия регионов за короткое время переориентировалась на российского туриста.

Сфера туризма имеет способность быстро восстанавливаться после всевозможных катаклизмов, так как потребность в путешествиях никуда не уходит. В настоящий период идет трансформация основных туристских направлений и перераспределение турпотоков.

Наиболее пострадала от пандемии высокоширотная часть Западной Арктики, которую традиционно посещают в основном иностранные туристы. Были отменены все летние международные круизные рейсы на Северный полюс, в национальный парк «Русская Арктика», в Мурманск, Архангельск и на Соловецкие острова. С закрытием границ России российские туристы стали больше путешествовать внутри страны.

С частичным снятием ограничений значительно вырос спрос на немноголюдный, самостоятельный туризм в Республику Карелия и на Кольский полуостров. Россияне больше стали путешествовать небольшими группами и семьями на автомобилях. На Европейском Севере опять стал популярным самодеятельный спортивный туризм с пешими и велопоходами, водными сплавами с ночевкой в палатках в малонаселенных местах, где низок риск заразиться коронавирусом. Еще один тренд - самостоятельное планирование путешествия без использования услуг туроператора, что существенно снижает стоимость туристической поездки.

Во второй половине 2020 г. резко возросло количество заболевших в Архангельской области и Республике Карелия, однако серьезных ограничений по передвижению туристов не было введено, за исключением Соловецких 
островов, где необходимо было предъявлять справку об отсутствии коронавируса. В Мурманской области большую часть года были закрыты для въезда Ковдор, Апатиты, Кировск и Териберка. Ближе к концу года были сделаны некоторые послабления для поездок по этим популярным туристическим направлениям.

Для поддержки отрасли и «бюджетных» туристов была запущена программа Ростуризма «Кэшбэк за туры по РФ» - возврат денежных средств в размере $20 \%$ от стоимости тура при оплате картой «Мир».

Пик турпотока пришелся на новогодние каникулы, несмотря на введенные ограничения для туристов из других регионов. В мурманском аэропорту наблюдалось большое скопление туристов на входе в здание и при регистрации на рейс. Путешественников из Азии сменили туристы в основном из крупных городов России. Практически все места размещения в самых популярных в регионе центрах туризма были забронированы еще в конце ноября.

Самой популярной локацией на Новый год была Териберка, инфраструктура которой не смогла справиться с большим потоком гостей. Резко возросли цены на хостелы, квартиры, сдаваемые посуточно, отели, обслуживание в местном ресторане, а также на на услуги частного транспорта. В частности, стоимость проезда из аэропорта Мурманска в город доходила до двух тысяч рублей (при обычной стоимости около пятисот рублей). В немногочисленных магазинах Териберки образовались длинные очереди, продуктов на всех не хватало [3, с. 18].

Горнолыжные курорты Хибин были открыты в декабре в основном для жителей Мурманской области, а начиная с середины января 2021 г. были сняты все ограничения для туристов из других регионов. Также в конце декабря были введены чартерные авиарейсы в Мурманск с организованными туристскими группами россиян с зимней программой «Новогодние приключения в Русской Лапландии» [2].

В настоящее время сфера туризма проходит процесс трансформации, появились новые тренды. Потребитель туристского продукта, наряду со всеми подверженный негативному влиянию пандемии, изменился. Изменились интересы, требования к продукту, покупательная способность. То есть существует много факторов, которые в первую очередь влияют на сферу туризма.

Основной тренд - это повышение требований к соблюдению безопасности и санитарно-эпидемиологических норм. И у властей, и у потребителей появился ряд требований к гостиничному и туристскому бизнесу: прежде всего соблюдение дистанции, санитарная обработка помещений, арендуемого оборудования и одежды для занятий активными видами туризма. Это, очевидно, увеличит затраты на формирование турпродукта и, следовательно, приведет к повышению цены на него. Но при этом покупательная способность жителей крупных городов (это основные поставщики туристов на Кольский Север) значительно снизилась. Таким образом, несмотря на повышение себестоимости продукта, сохраняется необходимость удерживания цен на уровне, привлекательном для приезжих туристов, и поиска баланса между доступным туризмом для местных и высокой себестоимостью регионального турпродукта.

Необходимы меры поддержки отрасли и местных туристов, например, аналог программы туристического кэшбэка на региональном уровне 
для местных жителей. Это особенно актуально с учетом постпандемийного тренда, состоящего в том, что люди будут ездить недалеко и желательно на своем транспорте, так как это более безопасно в нынешних условиях: человек, мало взаимодействующий с другими, имеет меньшую вероятность заразиться [4].

По итогам 2020 г. из-за пандемии в большинстве регионов Европейского Севера ожидается общее снижение турпотока на 30-50\%, кроме Республики Карелия. Начиная с июля в Карелии отмечался взрывной рост турпотока на всех направлениях, гостиницы и турбазы были полностью заполнены. Во второй половине 2020 г. в Карелии самой популярной локацией стал Сортавальский район, где отмечалась практически $100 \%$ загрузка мест размещения вплоть до конца сентября. А поздней осенью были особо популярны карельские туры выходного дня из Москвы и Санкт-Петербурга.

По прогнозам, в 2020 г. общий турпоток в Мурманскую область должен был составить около 324 тыс. человек. Восстановление показателей 2019 г. (458 тыс. человек) ожидается в 2024-2025 гг. [5].

В условиях продолжающейся пандемии основными мерами по минимизации потерь туриндустрии должны стать: всесторонняя господдержка отрасли, сохранение рабочих мест, возможность для туристской отрасли работать, а для людей - путешествовать безопасно и доступно. Планируется третий этап программы туристического кэшбэка.

Необходимо отметить беспрецедентные меры господдержки, которые в 2020 г. стали доступны для туристического бизнеса Арктического региона. Это налоговые льготы, льготное финансирование инвестиционных проектов, инфраструктурная поддержка. Было принято решение распространить на Арктику сервис, который уже работает на Дальнем Востоке «дальневосточный гектар». Он позволит частному турбизнесу бесплатно брать землю в пользование, а затем и в собственность. Опыт Дальнего Востока показал, что земельные участки часто берут для размещения турбаз, кемпингов и глэмпингов. В Российской Арктике сервис был запущен 1 июня 2021 г. В сентябре 2020 г. Российская Арктика стала самой большой в мире особой экономической зоной $\mathrm{c}$ беспрецедентными преференциями для новых инвестиционных проектов стоимостью от 1 млн рублей [5].

Для развития туристической отрасли в Заполярье необходимо создавать соответствующую инфраструктуру. В 2020 г. в Мурманской области увеличен с 4 до 10 млн рублей объем субсидии, направленной на реализацию инфраструктурных проектов - создание и обустройство гостиничных, туристско-рекреационных комплексов, а также организацию мероприятий по сохранению промыслов и локального продукта. Главной мерой государственной поддержки отрасли в период пандемии стал ежегодный конкурсный отбор проектов в сфере внутреннего и въездного туризма на территории Мурманской области. В рамках конкурса в 2020 г. было рассмотрено более ста заявок. Пятнадцать компаний-победителей получили субсидии на общую сумму 10 млн рублей. В числе проектов - создание придорожного сервиса, обустройство гостиничной инфраструктуры, строительство спа-комплекса, туристических объектов и объектов общественного питания, a также приобретение профильного специализированного туристского оборудования [6]. 
Еще один инструмент поддержки - конкурс долгосрочных бизнеспроектов, который проводит компания «Норникель». Участникам предлагается реализовать индустриально-инвестиционные и культурно-выставочные проекты на прекратившей работу производственной территории в Печенгском районе с применением ряда поддерживающих инструментов - от субсидии на оплату процентов по кредиту до софинансирования проекта. Власти уверены, что активная господдержка туризма в целом способна повысить инвестиционную привлекательность региона.

В пандемийный и постпандемийный периоды необходимо уделить особое внимание развитию активных видов природного и экотуризма в немноголюдных местах, индивидуальным и семейным турам, автомобильному и велотуризму. Среди новых направлений северного туризма после снятия ограничений станут детокс-туры и digital-туризм. Детокс-туртерапия - это отдых, совмещенный с очищением организма от вредных токсинов крупных мегаполисов в малолюдных местах. И все это в условиях экологически чистой окружающей среды Севера. Digital-туризм - это эксклюзивный турпродукт c цифровыми технологиями. Имеет перспективу также развитие инновационного вида экологического отдыха - плоггинга («мусорные забеги»), получившего широкое развитие в странах Скандинавии. Плоггинг - это экологическое движение, основанное на сочетании бега трусцой (джоггинг) со сбором мусора, т. е. он сочетает физические нагрузки с заботой о чистоте окружающей среды. За право участия в забеге-плоггинге участники обычно платят небольшой оргвзнос.

Среди инновационных видов инфраструктуры экологического туризма наиболее перспективны глэмпинги, получившие широкое распространение в странах Северной Европы. Глэмпинг - это благоустроенный кемпинг со всеми удобствами. Начиная с 2018 г. первые глэмпинги начинают появляться и на Европейском Севере России - в Мурманской области и Республике Карелия. Наиболее известный глэмпинг - «Аврора Вилладж», расположен в 50 километрах от Мурманска в сторону Териберки. Туркомплекс из десяти купольных домиков с панорамными окнами, кафе и всеми удобствами в тундре предназначен прежде всего для наблюдения за северным сиянием. В зимний период стоимость проживания в доме на четверых составляет 20 тыс. рублей, летом цены снижаются до 6 тыс. рублей в сутки.

Российские эксперты и аналитики сформулировали некоторые тенденции и прогнозы относительно развития арктического туризма в посткоронавирусный период.

1. Отложенный спрос на турподукты. Как только эпидемиологическая ситуация стабилизируется, административные ограничения будут отменены, а первостепенные потребности людей удовлетворены, начнёт реализовываться значительный отложенный спрос на туристские продукты, сформированный в период самоизоляции. Так как покупательная способность населения будет ниже, чем в докризисный период, а потребность в путешествиях, усиленная карантином, повысится, наиболее востребованными окажутся сравнительно недорогие направления.

2. Изменение конъюнктуры рынка. На развитие арктического туризма окажет влияние существенное изменение конъюнктуры рынка. Для граждан России внутренние направления туризма окажутся более предпочтительными 
по сравнению с выездными. Российская Арктика может оказаться востребована иностранными туристами из-за своей сравнительно низкой стоимости. Однако вряд ли можно ожидать быстрого возвращения международного туристского трафика на докризисный уровень.

3. Смена акторов. По всей видимости, значительно пострадают все участники малого и среднего бизнеса, не исключая и самых крупных игроков, ориентированных на сверхдорогие турпродукты, которые в условиях отсутствия иностранных туристов вынуждены будут либо делать свои услуги доступнее, либо переводить свою активность из Арктической зоны в другие регионы [7].

4. «Обнуление» направлений и брендов. В сложившейся ситуации, когда происходит переформатирование мировой экономики, туристская индустрия в целом, включая её арктический сегмент, столкнётся с фактическим «обнулением» всех исходных позиций. После периода карантина многие направления и бренды придётся во многом воссоздавать заново, так как поменяются конъюнктура и участники рынка, а многие популярные направления исчезнут. Это откроет окно возможностей для новых игроков, создающих и продвигающих бренды или пытающихся закрепиться на освободившихся после карантина сегментах рынка. При этом нельзя исключить возможность полной ликвидации некоторых направлений туризма в Российской Арктике по причине длительного отсутствия спроса.

Произойдёт также «обнуление» восприятия самого арктического туризма в качестве элитарного вида отдыха. На долгое время угаснет одна из самых дорогих составляющих этого направления - ледокольные круизы к Северному полюсу, что вряд ли серьёзно отразится на деятельности ФГУП «Атомфлот», для которого они были только дополнительным источником дохода. Одновременно возможен всплеск интереса к наиболее логистически доступным арктическим дестинациям России, локализованным на побережьях Баренцева и Белого морей и близлежащих островах. При благоприятном развитии событий в среднесрочной перспективе Российская Арктика может стать популярным и даже модным направлением постпандемийного мира, отвечая пожеланиям потребителей об экологически чистом и уединённом месте отдыха, которое отлично подходит для эмоциональной разгрузки.

В случае реализации пессимистических вариантов, арктический туризм, имеющий высокую себестоимость и организуемый в тяжёлых климатических и транспортных условиях, уступит свои позиции направлениям, имеющим курортно-рекреационную специализацию, которые территориально гораздо доступнее, сам же он станет уделом немногих сторонников экстремального отдыха.

5. Трансформачия арктического туризма. Происходящие в мире процессы, по всей видимости, приведут и к трансформациям туризма в Арктике. Он, вероятно, будет постепенно уходить от пакетных туров в сторону самостоятельного планирования поездок с использованием онлайн-сервисов. В связи со снижением покупательной способности населения увеличится число путешествующих «дикарями», а доля планируемых заранее турпоездок неизбежно снизится, особенно в первые постпандемийные месяцы [7]. 


\section{2. ЗАПАДНАЯ АРКТИКА}

\section{1. Евро-Арктическая зона России}

Комплексное развитие Евро-Арктической зоны Российской Федерации должно быть направлено и на стимулирование туристской деятельности. Это одно из приоритетных направлений социально-экономической деятельности, обусловленное высоким природно-культурным потенциалом Российской Арктики и мультипликативным эффектом отрасли туризма. Арктический туризм является стратегическим направлением устойчивого развития северных регионов, он может стать фактором защиты уникального природного и культурного наследия и важнейшим драйвером экономического развития Российской Арктики.

В результате глобального потепления климата с тающим морским льдом открывается все больше арктических вод для круизных судов и навигации в летнее время. Доступнее становятся не только материковые, но и островные высокоширотные территории.

В Евро-Арктическую зону РФ (Западная Арктика) входят: морская акватория Северного Ледовитого океана (Баренцевоморский регион) с высокоширотными островными территориями, вся Мурманская область, Ненецкий автономный округ, северные районы Архангельской области и Республики Карелия, примыкающие к Белому морю (рис. 1).

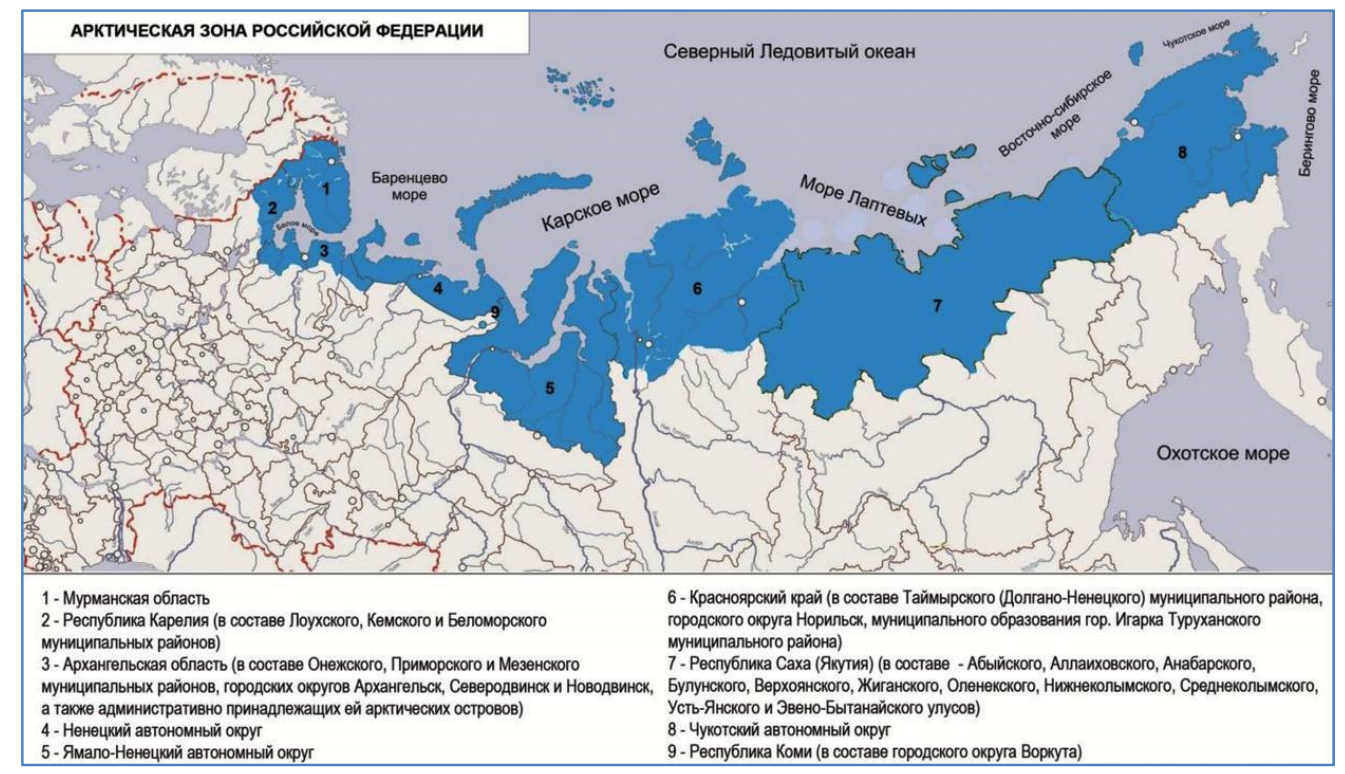

Рис. 1. Карта Арктической зоны РФ. Источник: Лукин Ю. Ф., Еремин А. Э. Архангельск, 2011

Как показывает статистика, Арктическая зона является одним из самых перспективных направлений в туризме. В 2019 г. в Российской Арктике побывали 1,17 млн туристов. Мурманская область - один из лидеров по количеству гостей, 
принимает до 40 \% всех туристов Арктики. Наряду с Мурманской областью активно принимают туристов в Архангельской области - $18 \%$ от общего их числа, в Республике Карелия - 15 \%.

Мурманская область является основным арктическим регионом развития туризма в России. Это связано с ее наиболее выгодным экономикогеографическим положением по сравнению с другими арктическими регионами, наилучшей транспортной доступностью для туристов из крупных городов центра России, наличием развитой туристской инфраструктуры.

Одной из ключевых территорий развития арктического туризма является Приморский район Архангельской области - крупнейший административный район России, включающий такие популярные центры туризма, как архипелаг Земля Франца-Иосифа, Соловецкие острова, Малые Корелы, национальный парк «Онежское Поморье». Если высокоширотный летний арктический туризм в большей степени ориентирован на иностранных туристов, то материковая часть Западной Арктики привлекательна в основном для российских граждан.

Россия обладает колоссальными инфраструктурными и природными возможностями для туристского освоения Арктики с учетом важности сохранения уникальной экосистемы региона и уклада жизни коренных малочисленных народов Крайнего Севера.

Проблемы развития туризма в западном секторе Арктики, обусловленные высокой стоимостью туристских и транспортных услуг, неразвитостью дорожно-транспортной инфраструктуры, отсутствием судов ледового класса, институциональными и природоохранными ограничениями, а также недостаточно высоким уровнем жизни населения в РФ, не позволяют рассчитывать на массовый высокоширотный арктический туризм в ближайшей перспективе [8, с. 96].

Туризм в Западной Арктике имеет свою региональную специфику, связанную с суровыми природно-климатическими условиями и необходимостью обеспечения безопасности пребывания здесь туристов. Кроме этого, для арктических особо охраняемых природных территорий (ООПТ) вопрос транспортной доступности представляется весьма важным, а составляющая морского либо воздушного путешествия в высокоширотную Арктику для туристов играет большую роль.

При разработке перспективных мероприятий, направленных на повышение привлекательности высокоширотных западно-арктических архипелагов для целей развития туризма, следует исходить из особенностей географического расположения этих территорий. Прежде всего, необходимо учитывать труднодоступность территории, островное морское расположение, суровые климатические условия и явно выраженную сезонность, что не позволяет говорить о возможности круглогодичного её посещения. Отдалённость территории от крупных транспортных узлов и приоритет использования морского транспорта для достижения островных территорий определяют большие расходы на организацию морских круизов, которые преобладают в арктическом туристском бизнесе [9, с. 116-122].

Арктический туризм остается дорогостоящим продуктом, так как высокая цена морских круизов объективно сдерживает развитие высокоширотного туризма для многих социальных групп населения внутри России. Ключевой проблемой в организации туристских потоков остаётся учёт 
оптимальной ёмкости ООПТ для принятия определённого количества туристов с позиций экологии. Баланс экономики и экологии в сфере арктического туризма не менее важен, чем в других отраслях [9, с. 116-122].

Развитие туризма в Арктике осложняется жесткими природоохранными ограничениями, запретом на создание туристических объектов на ООПТ, где находятся наиболее привлекательные экологические маршруты региона. Для решения накопленных проблем в арктическом туризме необходимо: создание мини-туристских кластеров на границах ООПТ, создание стимулов для инвесторов и местных властей развивать туризм, организация новых международных и межрегиональных маршрутов. С целью повышения экономической эффективности и окупаемости маршрутов необходимо формировать трансграничные туры с соседними странами Баренцева региона [10].

Для развития туризма в Арктике требуются очень существенные инвестиции в инфраструктуру, отмена административных препятствий, облегчение визового режима и введение электронных виз.

В регионах Западной Арктики реализуется комплексная программа сохранения и развития уникальных природно-ландшафтных и историкокультурных территорий и памятников природы на основе создания новых и устойчивого развития существующих ООПТ, вовлеченных в сферу экологического туризма. Возрождаются отдаленные поморские поселения посредством развития событийного туризма (Териберка, Кузрека, Умба), обустраиваются новые экологические тропы. На беломорском побережье наряду с дайвингом и сельским туризмом набирает популярность экологический «уотш туризм» - наблюдение за морскими животными (Кандалакша, национальный парк «Онежское Поморье», карельская Нильмогуба, поморская Летняя Золотица, белужий мыс на Соловках).

Характерной особенностью историко-культурного наследия Арктики является то, что значительная часть его не обладает самостоятельной туристской привлекательностью. Для интеграции некоторых памятников в практики туриндустрии необходима их целенаправленная актуализация: включение в экскурсионные маршруты, популяризация, музеефикация и т. п. При этом часть объектов, обладающих историко-культурной ценностью, не подходит для использования в массовом туризме (например, действующие или законсервированные объекты военной инфраструктуры региона).

Интеграция материального и нематериального историко-культурного наследия Арктики в туристскую деятельность сопряжена с рядом потенциальных угроз. Помимо опасностей, связанных с увеличением трафика и развитием инфраструктуры, схожих по своему генезису с проблемами, создаваемыми туризмом для экологической ситуации (риск изменения ценных культурных ландшафтов, повреждения или уничтожения памятников истории), взаимодействие историко-культурной среды и туриндустрии сталкивается с комплексом специфических вызовов [11, с. 177].

В целях регулирования неконтролируемого туристского потока, устойчивого развития экологического туризма и сохранения уникального природного наследия Российской Арктики, организуются новые ООПТ (природный парк на полуостровах Средний и Рыбачий, национальный парк «Хибины»).

Специфической особенностью туризма в Западной Арктике является организация туристской деятельности, связанная с преобладанием нишевых видов туризма (морские круизы, горнолыжный туризм), ориентированных 
на туристов с высоким уровнем дохода. Несмотря на то что нишевой туризм является дорогостоящим видом, его вклад в экономику субъектов Арктической зоны РФ составляет не более 1 \% из-за транспортной удаленности территорий, низкой инвестиционной активности регионов, низкой доходности некоторых видов туризма. Вследствие этого перспективными стратегическими направлениями развития сферы туризма Западной Арктики будет поддержка малозатратных и высокодоходных видов туризма, например событийного, этнографического и экологического [12, с. 206-211].

Путешествия в Арктику должны стать доступны туристам с различным уровнем доходов. Чтобы улучшить транспортную доступность и снизить цены на путешествие, необходимо развивать конкуренцию в логистике и транспортном обслуживании.

Одним из перспективных направлений диверсификации хозяйственной деятельности в малых поселениях Западной Арктики является развитие туризма. Инновационные инвестиционные проекты в сфере арктического туризма должны привлечь в регион туристов, а это, безусловно, привлечет дополнительные инвестиции в модернизацию инфраструктуры и дальнейшее устойчивое развитие уникальных территорий Западной Арктики.

Опыт соседних арктических стран показывает, что в основе формирования туристских кластеров в Арктике должно лежать рациональное природопользование, развитие транспортной и гостиничной инфраструктур. Предусматривается активное использование потенциала ООПТ арктического региона - национальных парков и заповедников, в которых целесообразно осуществлять природно-ориентированные виды туризма и экологическое просвещение рекреантов. Непременным условием эффективного осуществления и развития арктического туризма в современных условиях выступает фактор международного партнёрства и кооперации в целях обеспечения безопасности туризма в Арктике и транспортного осуществления арктических путешествий. Примером может являться проект «Государственно-частное партнёрство в сфере туризма в Баренц-регионе» (BART) [13, с. 33].

Ключевой проблемой арктического морского туризма является отсутствие собственных пассажирских судов в России. Теплоход «Клавдия Еланская» является единственным специализированным российским судном, курсирующим в арктических водах. Вице-президент Объединенной судостроительной корпорации Дмитрий Коломяжный заявил: «В России разрабатываются круизные суда ледокольного класса для создания туристских маршрутов по Арктике, что в будущем позволит получать более 5 млрд долларов в год». Существует возможность создания локальных маршрутов, например круиз Мурманск - Архангельск - Соловецкие острова [14].

В Мурманске в настоящее время реализован инвестиционный федеральный проект по развитию пассажирской инфраструктуры морского транспорта «Арктическая гавань» в целях создания круизного центра международного уровня. В 2018 г. в здании Мурманского морского вокзала начал работать международный пункт пропуска через границу, рассчитанный на пропуск порядка 100 тыс. человек в год. В связи с его обустройством в 2017 г. порт Мурманск принял только три круизных судна. В 2018 г. количество судозаходов в заполярную столицу увеличилось до семи (4500 туристов), в 2019 г. - до восьми, однако общее количество круизных пассажиров снизилось до двух тысяч (табл. 1). 
Морские круизы в порт Мурманск [15-17]

\begin{tabular}{|c|c|c|}
\hline Год & Количество судозаходов & Количество круизных туристов \\
\hline 2013 & 8 & 3705 \\
\hline 2014 & 11 & 4097 \\
\hline 2015 & 13 & 10306 \\
\hline 2016 & 6 & 2300 \\
\hline 2017 & 3 & 1500 \\
\hline 2018 & 7 & 4500 \\
\hline 2019 & 8 & 2000 \\
\hline
\end{tabular}

Открытие морского вокзала с обустроенным пунктом пропуска и безвизовым въездом туристов на 72 часа даст положительный эффект

в первую очередь для развития сферы услуг, локального туризма и транспортных маршрутов. Реализация проекта «Арктическая гавань» позволит организовать регулярное круизное и паромное сообщение с Норвегией и Архангельской областью и обеспечить увеличение круизных заходов иностранных судов в порт.

В перспективе норвежская круизная компания «Хуртигрутен» собирается продлить круизный и паромный рейсы до Архангельской области с посещением Архангельска и Соловецких островов. Компания «Хуртигрутен» совместно с российской компанией «Атлантис Лайн» планировала организовать два первых пилотных рейса из Киркенеса в Мурманск и Архангельск в 2019 г. $[15,16]$. Однако норвежская компания решила изменить географию круиза, предложив маршрут Тромсе - Мурманск - Земля Франца-Иосифа. Два круиза, намеченных на 2019 г. по данному маршруту, не состоялись по причине проведения в районе архипелага Земля Франца-Иосифа военных учений Минобороны РФ. На круизном лайнере планировали отправиться в двенадцатидневное путешествие 250 пассажиров, заплативших за каждую путевку 6,2 тыс. долларов [18].

Представители компании надеются, что отмена круизов в 2019-2020 гг. из-за военных и коронавирусных ограничений будет временной и круизы состоятся в обозримом будущем.

\section{2. Высокоширотные архипелаги Западной Арктики}

Основными перспективными центрами арктического туризма в высоких широтах становятся архипелаг Шпицберген и национальный парк «Русская Арктика», организованный на архипелагах Земля Франца-Иосифа и Новая Земля. Архипелаги Шпицберген и Земля Франца-Иосифа могут стать одной из точек роста российского арктического туризма как геополитического фактора усиления присутствия России в Западной Арктике.

\subsection{1. Архипелаг Шпицберген}

Один из наиболее привлекательных районов Арктики в настоящее время - архипелаг Шпицберген, который посещает ежегодно около 80 тыс. туристов (рис. 2). Норвегия дотирует архипелаг Шпицберген, создала там поселение 
с губернатором на постоянной основе в городе Лонгйир, ставшем популярным туристическим центром. Туристы прибывают туда на самолетах, а далее садятся на круизные суда и совершают туристические рейсы. Власти Шпицбергена отчитались, что в 2016 г. индустрия туризма вышла на первое место, сместив добычу угля. Шпицберген доступнее и комфортнее (в климатическом и инфраструктурном плане), чем другие высокоширотные направления в Арктике. Если в «Русской Арктике» туристический сезон длится примерно три летних месяца, то на архипелаге Шпицберген - до шести месяцев из-за влияния теплого Гольфстрима [19].

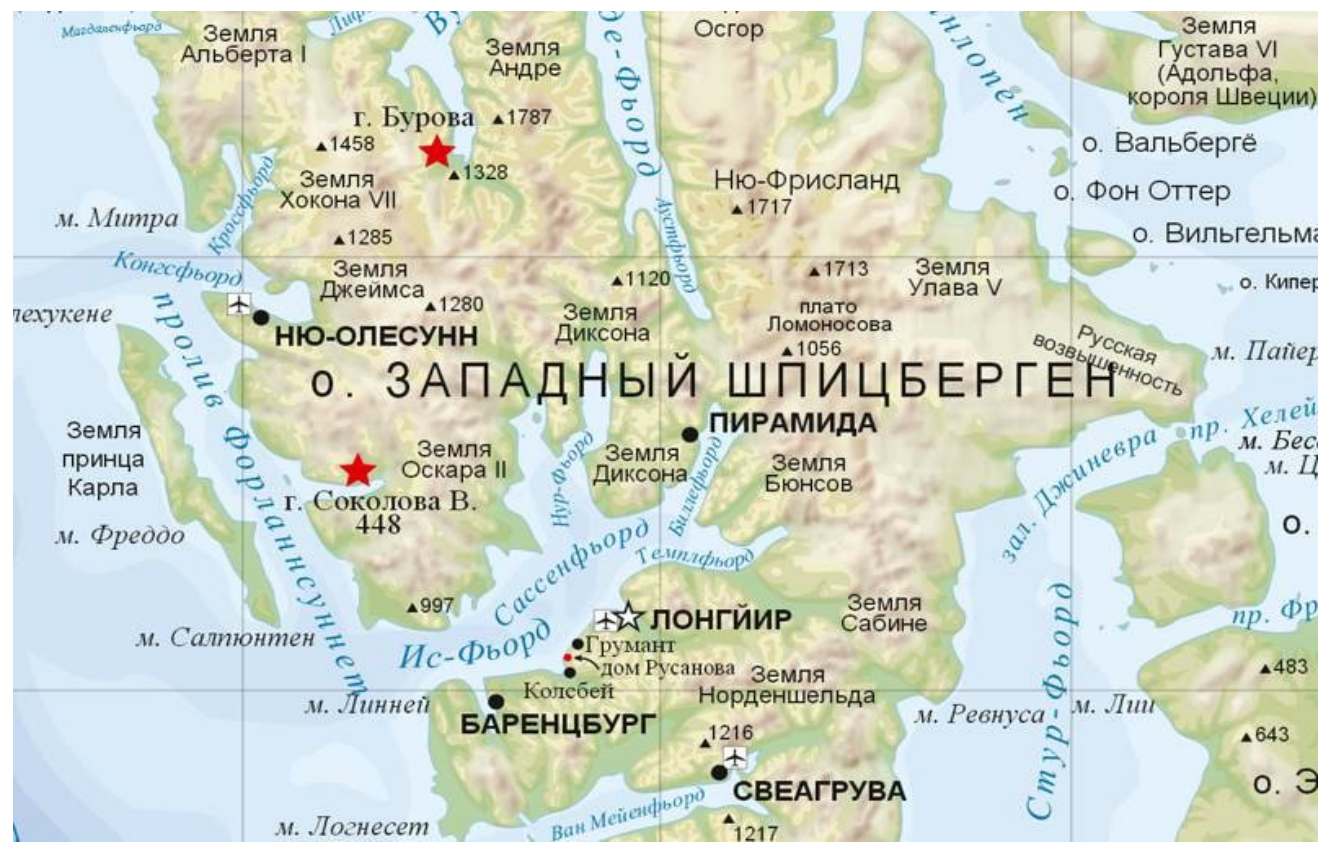

Рис. 2. Архипелаг Шпицберген

Из Москвы полет в оба направления стоит 30 тыс. рублей с пересадкой в Осло [20]. Для туристов российский поселок Баренцбург на норвежском архипелаге Шпицберген - это контраст между красотой нетронутой арктической природы и промышленным освоением в советском духе. В настоящий период Баренцбург меняет свою экономическую специализацию, чтобы стать современным российским центром для любителей экспедиционного туризма.

Как и в норвежской части архипелага, добыча угля в Баренцбурге нерентабельна. В компании «Арктикуголь» работает 150 человек, каждый третий житель моногорода. Именно «Арктикуголь» стал инициатором развития туристического направления. В рамках собственной структуры компании создан Центр арктического туризма «Грумант» (ЦАТ «Грумант»). В последние годы в Баренцбурге активно развивается современная туристская инфраструктура, в которую вложены немалые средства. В результате туристский поток в российскую часть архипелага неуклонно растет. В 2017 г. Баренцбург посетило 32 тыс. человек (из них 600 россиян), что принесло доход в 120 млн 
рублей. По данным ЦАТ «Грумант», в последние годы турпоток увеличился до 38 тыс. человек.

Центр арктического туризма «Грумант» в настоящее время становится самым крупным российским туроператором в Арктике. Помимо традиционных для Шпицбергена видов туризма (экологический, снегоходные туры, круизные прогулки), набирает популярность подземный промышленный туризм с показом угольных шахт. В поселке создано 70 рабочих мест в сфере туризма и услуг. В перспективе сфера туризма будет расти, а добыча угля — сокращаться. Количество рабочих мест в ЦАТ «Грумант» может увеличиться с нынешних 18 до 100 [21]. Кроме Баренцбурга туристы посещают и законсервированные советские поселения Грумант и Пирамида.

Баренцбург постепенно становится туристическими воротами в Российскую Арктику. Круизные лайнеры теперь могут напрямую идти от Шпицбергена до Земли Франца-Иосифа и на Северный полюс (до которых около 1000 километров), в Баренцбурге налажена выдача туристам российских виз. Количество российских туристов на Шпицбергене может вырасти благодаря организации морских круизов, увеличению числа чартерных или регулярных авиарейсов из Мурманска или Москвы.

Центр арктического туризма «Грумант» организовал и разработал первый российский арктический круиз на Шпицберген в августе 2016 г. на борту норвежского судна с организацией прямого чартерного авиарейса из Москвы. Стоимость недельного безвизового путешествия для 108 российских туристов составила от 2800 до 3500 евро в зависимости от класса кают [22].

В дальнейшем для организации прямых круизных рейсов по маршруту Мурманск - Баренцбург необходим поиск судна, которое сможет осуществлять круизы на Шпицберген, возможно, с посещением полуострова Рыбачий и мыса Немецкий. Однако круизных судов ледового класса в мире мало. Для этого нужны вложения крупного венчурного фонда или государства. Возникнет также необходимость субсидирования коммерческой компании, которая приобретет судно для морских круизов на Шпицберген. В поселках Баренцбург и Пирамида необходима реконструкция причальных комплексов, что потребует вложения дополнительных средств.

В ряду новых перспективных конкурентоспособных направлений развития туризма в российской части Шпицбергена следует отметить развитие горнолыжного, событийного и лечебно-оздоровительного (на базе источников минеральной воды «Баренцбургская») его видов.

\subsection{2. Национальный парк «Русская Арктика»}

В настоящее время идет процесс развития национального парка «Русская Арктика», основанного в 2009 г. В его состав были включены северная часть архипелага Новая Земля и архипелаг Земля Франца-Иосифа. Это самая северная и самая крупная морская ООПТ в Арктике, 85 \% архипелага покрыто ледниками.

В 2016 г. территория национального парка «Русская Арктика» была расширена на 7,4 млн га за счет федерального заказника «Земля ФранцаИосифа» площадью 1,6 млн га и участка внутренних морских вод и территориального моря России площадью 5,8 млн га. Таким образом, национальный парк «Русская Арктика» стал самой большой в России ООПТ 
площадью 8,8 млн гектаров [23]. Это также самый крупный сухопутный национальный парк и морской природный резерват в России. Расширение парка будет способствовать сохранению арктических редких видов животных и птиц, внесенных в Красные книги России и мира, а также их местообитаний.

На территории парка располагаются крупнейшие в Северном полушарии птичьи базары, лежбища моржей, обитают белые медведи, гренландский кит, тюлени и нерпы. Парк создан для сохранения уникальной природы Арктики. На архипелаге Земля Франца-Иосифа нет постоянного населения.

Основным видом доставки туристов является морской круизный туризм, который составляет одну из стратегических задач развития национального парка. В связи с его созданием ледокольные круизы на Северный полюс выполняются из Мурманска в последнее время в основном через Землю ФранцаИосифа с заходом на Новую Землю.

В 2015 г. на архипелаге Земля Франца-Иосифа (остров Земля Александры) был открыт пограничный морской пункт пропуска для иностранных туристов в тестовом режиме, что позволило упростить погранично-таможенные процедуры и сократить на трое суток путь круизных рейсов по транзитному маршруту от Шпицбергена до Земли Франца-Иосифа без захода судов в Мурманск или Архангельск (рис. 3). Начиная с 2015 г. Ростуризм и компания Poseidon Expeditions стали организовывать в среднем по три ежегодных экспедиционных круиза для иностранных туристов (500 человек) на судне Silver Spirit с посещением архипелагов Шпицберген и Земля ФранцаИосифа. Ночной переход из порта Лонгйира на архипелаг длится всего двенадцать часов. Пограничный осмотр происходит на борту судна. Такой способ посещения национального парка «Русская Арктика» через Шпицберген обходится в 6 тыс. евро. Этот путь может стать альтернативой строительству гражданского аэродрома на архипелаге. Важным шагом, который позволит увеличить турпоток в «Русскую Арктику», будет создание зоны таможенного контроля на острове Земля Александры, так как это самый ближайший к Шпицбергену остров архипелага Земля Франца-Иосифа.

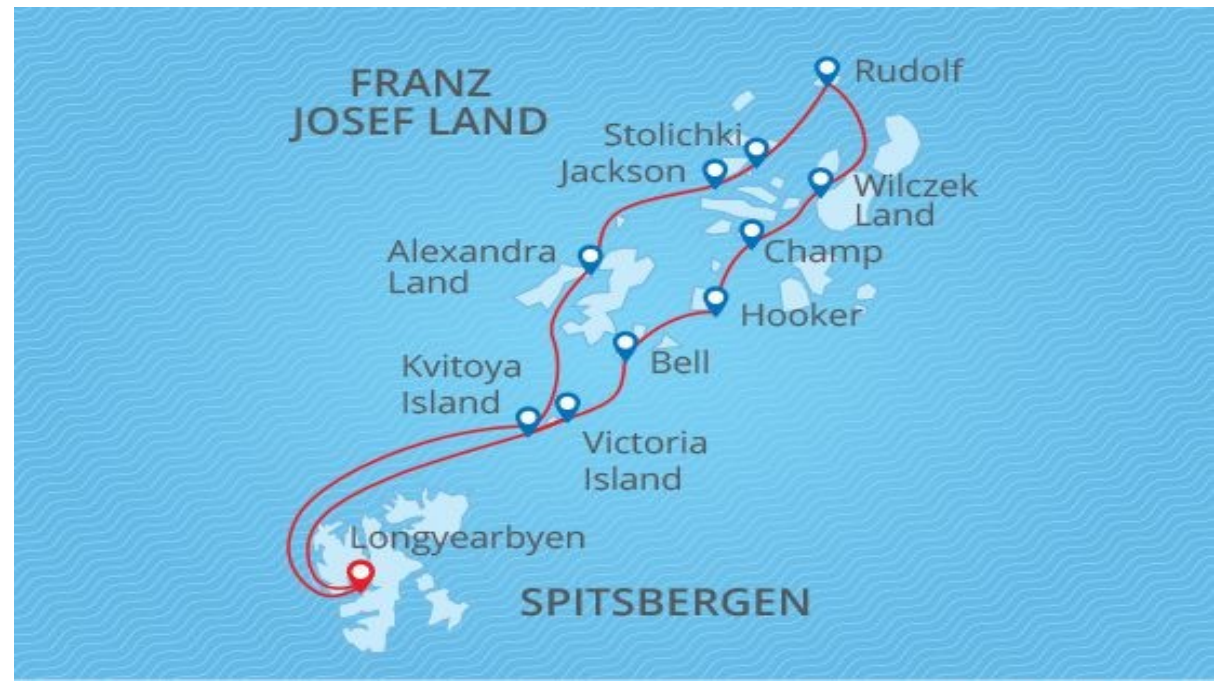

Рис. 3. Карта круиза Шпицберген - национальный парк «Русская Арктика» 
Самый дешевый тур со Шпицбергена в «Русскую Арктику» на восемь дней стоит 3450 евро, а на десять дней - 4100 евро. Тогда как самый дешевый турпродукт из Мурманска на Землю Франца-Иосифа стоит минимум в два раза дороже (9 тыс. евро) и длится 14 дней [19].

Стоимость участия в круизе на атомном ледоколе «50 лет Победы» составляет от 28 до 40 тыс. долларов, в среднем на борту около 120 пассажиров, преобладают туристы из Китая, стран Азии, Западной Европы. Ежегодно национальный парк «Русская Арктика» посещает чуть более 1 тыс. туристов (табл. 2), россиян до последнего времени было немного — не более 5 \% [23].

Таблица 2

Морские круизы в национальный парк «Русская Арктика» [23]

\begin{tabular}{|c|c|c|c|c|c|}
\hline Показатель & 2015 г. & 2016 г. & 2017 г. & 2018 г. & 2019 г. \\
\hline Количество & 11 & 9 & 12 & 10 & 17 \\
\hline Количество туристов & 1225 & 954 & 1142 & 1079 & 1306 \\
\hline
\end{tabular}

В 2019 г. национальный парк «Русская Арктика» посетило рекордное количество туристов за всю историю парка - 1306 человек. Всего состоялось шесть рейсов на атомном ледоколе «50 лет Победы» по маршруту Мурманск Северный полюс - Мурманск, три рейса на судне Sea Spirit по маршруту Шпицберген - Земля Франца-Иосифа - Шпицберген, на территорию парка заходили лайнеры «Бремен» и Silver Explorer. Кроме больших судов на Землю Франца-Иосифа приходили яхты. Всего было осуществлено семнадцать круизов.

Впервые за время существования парка больше всего посетителей оказалось из России - 262 человека $(20 \%$ от общего потока). Обычно большинство туристов из Китая. Китай в этот раз на втором месте 255 гостей. Третье место у США - 193 туриста [24].

С отменой ограничений в постпандемийный период на территории «Русской Арктики» планируют начать регулировать поток туристов. Предполагается чередовать острова между круизами, чтобы не было высадок за короткое время подряд на один остров. Когда с судна одновременно сходит 100-120 человек с разницей в неделю - это большая антропогенная нагрузка на экосистемы острова.

Необходимо отметить, что в круизах большое внимание уделяется бережному отношению к природе Арктики при организации высадок туристов на острова. Сохранение уникального ландшафтно-геологического и историкокультурного наследия национального парка стоит в центре внимания организаторов ледокольных круизов.

В национальном парке «Русская Арктика» обустроена первая экологическая тропа, необходимость ее организации связана с увеличившимся потоком туристов. Экотропа расположена в бухте Тихой острова Гукера архипелага Земля Франца-Иосифа. На предложенном маршруте туристы смогут увидеть не только памятники природы, но и наследие человеческого присутствия на арктическом архипелаге. Экологическая тропа поможет сохранить хрупкую экосистему бухты и упорядочить поток туристов. Вдоль тропы появится экспозиция под открытым небом самого северного музея 
в мире - музея освоения Арктики имени Виллема Баренца - на базе бывшей полярной станции.

В 2019 г. на острове Гукера был открыт самый северный в России визитцентр. Создание его интерактивной экспозиции связано с планами национального парка по расширению комплекса туристских услуг в бухте Тихой. В последние годы уровень и перечень услуг для посетителей бухты значительно возросли: организуется сеть благоустроенных экологических троп на основе прокладки каменных дорожек и деревянных пешеходных настилов, туристская навигация, самая северная в мире почта и сувенирная лавка [23].

Музейные экспозиции планируется организовать также на островах Земля Александры и Греэм-Белл, продолжится работа над созданием новых экологических троп на мысе Флора острова Нортбрук и в районе мыса Желания острова Северный на Новой Земле [25].

Высокие широты - это огромные издержки, в первую очередь транспортные. Фрахт атомного ледокола обходится в четыре миллиона рублей в сутки, плюс обеспечение круиза и услуги туристам. Даже с учетом строительства новых ледоколов можно утверждать, что арктический туризм на круизных судах не будет дешевым. Однако есть и другие виды путешествий, которые могут сделать Арктику более доступной в финансовом отношении.

Основную проблему составляет логистика. Авиатехника дешевле и быстрее, морская техника - медленнее и дороже. Чем меньше турист находится на воде, тем меньше будет стоить тур. На Земле Франца-Иосифа в настоящее время нет гражданского аэродрома, способного принимать туристов. Поэтому приходится добираться до национального парка морем из Архангельска или Мурманска, на что уходит два дня чистого времени в море и столько же обратно [19].

С этой целью национальный парк начинает развивать стратегию авиатуризма. Для этого понадобится задействовать один-два ведомственных аэродрома на северных архипелагах. Предполагается, что туристов из Архангельска, Нарьян-Мара или других городов будут вертолетами доставлять, например, на Новую Землю. Там для них построят гостиницу на 50-70 мест. Затем они на небольших судах в течение пяти-семи дней смогут путешествовать по арктическим островам, после чего тем же путем вернутся на материк. Подобные проекты разрабатываются для острова Хейса Земли Франца-Иосифа и для мыса Желания на Новой Земле. Есть проекты гостиниц, многофункциональных арктических комплексов (МАК) [26].

Руководство национального парка считает развитие инфраструктуры для ночевки круизных туристов с атомохода на архипелаге ненужной затеей. Туристы высаживаются на берега и так, а вот остаться переночевать на берегу хотят, как правило, один-два туриста из 120 человек на борту. «Если построить на Земле Франца-Иосифа аэродром для гражданских самолетов, то туристы смогут сразу прилететь в акваторию национального парка, где уже стоит судно, готовое принять их на борт. На самолете можно долетать за три часа в одну сторону. Таким образом сокращается время доставки туристов в Арктику. Во-вторых, снижаются затраты и издержки на туристическую поездку по осмотру архипелага», - считает директор национального парка «Русская Арктика» Александр Кирилов. В итоге вместо четырнадцати дней на круизном судне и четырех дней в море, тур сокращается до десяти дней. Цена при этом, при условии постоянного роста турпотока, может снизиться если не в два, 
то в полтора раза. Однако проблема здесь в том, что ни одна частная компания построить аэродром в Арктике не может, в том числе из-за дороговизны, a у государства пока планов таких нет [19]. Для авиатуров необходимо использовать существующие ведомственные аэродромы.

Организация МАК, своего рода «мест сбора» туристов с вертолетными площадками в «Русской Арктике», которые могут посетить туристы и ученые, способна существенно снизить цену туров. Так, в районе самой северной погранзаставы в мире - на острове Земля Александры Земли Франца-Иосифа создаются объекты инфраструктуры оборонного значения, в том числе строится военный аэродром, который в перспективе можно использовать для организации авиатуров. Разрабатывается программа стационарного пребывания туристов на острове Земля Александры, рассчитанная на 3-5 дней [27].

Еще одно перспективное направление - экстремальный яхтенный туризм. В последнее время яхты все чаще заходят в высокие широты. Но для развития яхтенного туризма на наших арктических территориях необходимо создать соответствующую инфраструктуру. В круизном яхтинге можно найти разные варианты - дорогие и комфортные или дешевые и демократичные. Например, поморская шхуна как туристическое и научноэкспедиционное судно может быть востребована именно в высоких широтах [26].

Создание системы МАК, постоянного пограничного пункта пропуска, организация экологических троп, музейных экспозиций и визит-центров в национальном парке «Русская Арктика» будет способствовать увеличению заходов круизных судов, устойчивому развитию экологического туризма и росту туристского потока. 


\section{3. МУРМАНСКАЯ ОБЛАСТЬ}

Мурманская область является регионом, привлекательным для туристов, благодаря своему расположению и уникальным природно-географическим условиям. Мурманская область, омываемая сразу двумя морями, имеет самую длинную в России береговую полосу. Даже студеное северное море дает уникальные возможности для отдыха и путешествий. Росту популярности туризма на Кольском полуострове способствует большое разнообразие природных условий. В Мурманской области соседствуют тундра, лесотундра, леса, горы, моря, реки и озера. На ее территории расположено более 111 тыс. озер, 20 тыс. рек, в которых водятся ценные породы рыб, а семга является настоящей визитной карточкой региона.

Анализ современного состояния туризма в Мурманской области позволяет сделать выводы о положительной динамике в развитии этой сферы. Отмечается ежегодный рост внутреннего и въездного туристского потока. Прирост туристического потока (около 20 \%) является результатом активного и грамотного продвижения Мурманской области как туристического направления на внутреннем и международном рынках. В связи с этим туристический бизнес региона также приносит существенный доход.

В 2018 г. регион посетило 438 тыс. туристов, из них иностранных туристов - около 64 тыс. человек. В 2019 г. турпоток составил 458 тыс. человек (табл. 3) (из них $17 \%$ - иностранные туристы). В мурманский порт в летний сезон 2019 г. был осуществлен заход восьми круизных судов с 2 тыс. пассажиров [17]. Как правило, большинство прибывающих в Мурманскую область туристов осматривают Мурманск, крупнейший в мире город, расположенный за Северным полярным кругом. Основным объектом туристского показа в Мурманске является атомный ледокол-музей «Ленин» первое в мире надводное судно с ядерной силовой установкой. Около места стоянки атомохода, у морского вокзала (морской фасад) с миниатюрной набережной, в 2020 г. появилось новое общественное пространство с расписными лодками и благоустроенным сквером (рис. 4.).

Таблий 3

Туристский поток в Мурманскую область, тыс. человек [17]

\begin{tabular}{|l|r|r|r|r|r|}
\hline \multicolumn{1}{|c|}{ Показатель } & 2014 г. & 2016 г. & 2017 г. & \multicolumn{1}{c|}{2018 г. } & 2019 г. \\
\hline $\begin{array}{l}\text { Общее количество } \\
\text { туристов }\end{array}$ & 292 & 330 & 413,7 & 438 & 458 \\
\hline Российские & 271,3 & 291 & 361,8 & 374 & 381 \\
\hline Иностранные & 20,5 & 39 & 51,9 & $\begin{array}{r}64(12- \\
\text { Китай; } 7- \\
\text { Таиланд) }\end{array}$ & $\begin{array}{r}77(19- \\
\text { Китай })\end{array}$ \\
\hline
\end{tabular}




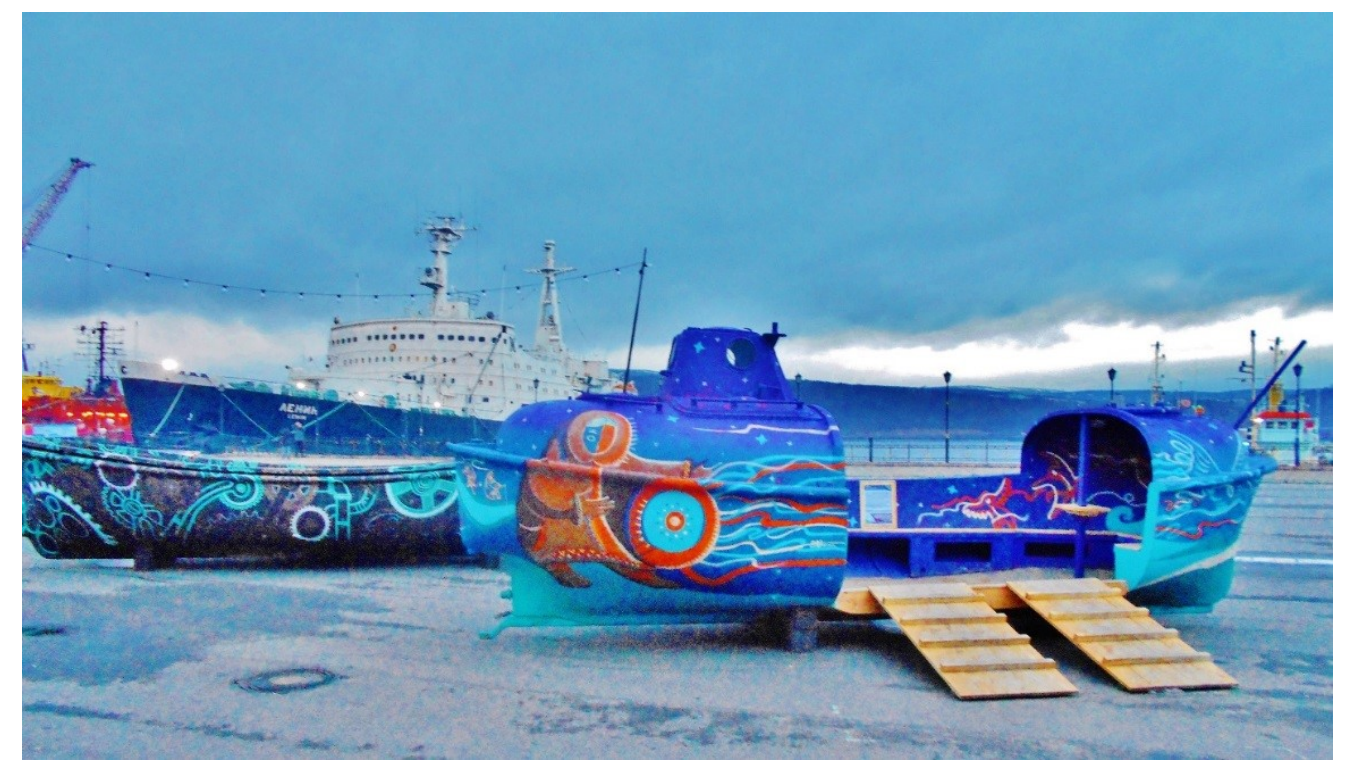

Рис. 4. Мурманск. Набережная морского вокзала

В настоящий период разрабатывается новый инвестиционный проект ревитализации «Новый Мурманск», который подразумевает строительство на берегу Кольского залива конгресс-центра, гостиницы, яхт-клуба, оборудование набережной, Арктического музея, зоны фуд-корта и рыбного рынка, кафе, под которые отдана территория бывшего судоремонтного завода. В проект включено развитие территорий авто-, морского и железнодорожного вокзалов и объединение их в единый транспортно-пересадочный узел. Из федерального бюджета на эти цели выделено 5 млрд рублей [28].

В рамках территории опережающего развития «Мурманск - столица Арктики» предусматривается также комплексное обновление аэропорта Мурманск и развитие его как узлового аэропорта с приемом дальнемагистральных судов в обход московского авиаузла.

По сравнению с соседними регионами РФ конкурентное преимущество Мурманская область имеет в следующих видах рекреационной деятельности: рекреационное рыболовство, наблюдение за северным сиянием, геологоминералогический, деловой, морской круизный, горнолыжный и лыжный (самый длинный в РФ снежный сезон) туризм.

Самым перспективным направлением туризма на Кольском Севере признан природно-ориентированный экотуризм. Большим рекреационным потенциалом обладают природные резерваты: заказники «Кутса» и «Сейдъявр», национальный парк «Хибины», природный парк «Полуострова Средний и Рыбачий», Лапландский заповедник и заповедник «Пасвик». Создание новых ООПТ - это не только ограничения, но и новые возможности для устойчивого развития территорий. При правильном регулировании в этом может помочь экологический туризм. Старинные заполярные села Териберка и Варзуга входят в число самых привлекательных сел России для экологического и сельского туризма (рис. 5). 


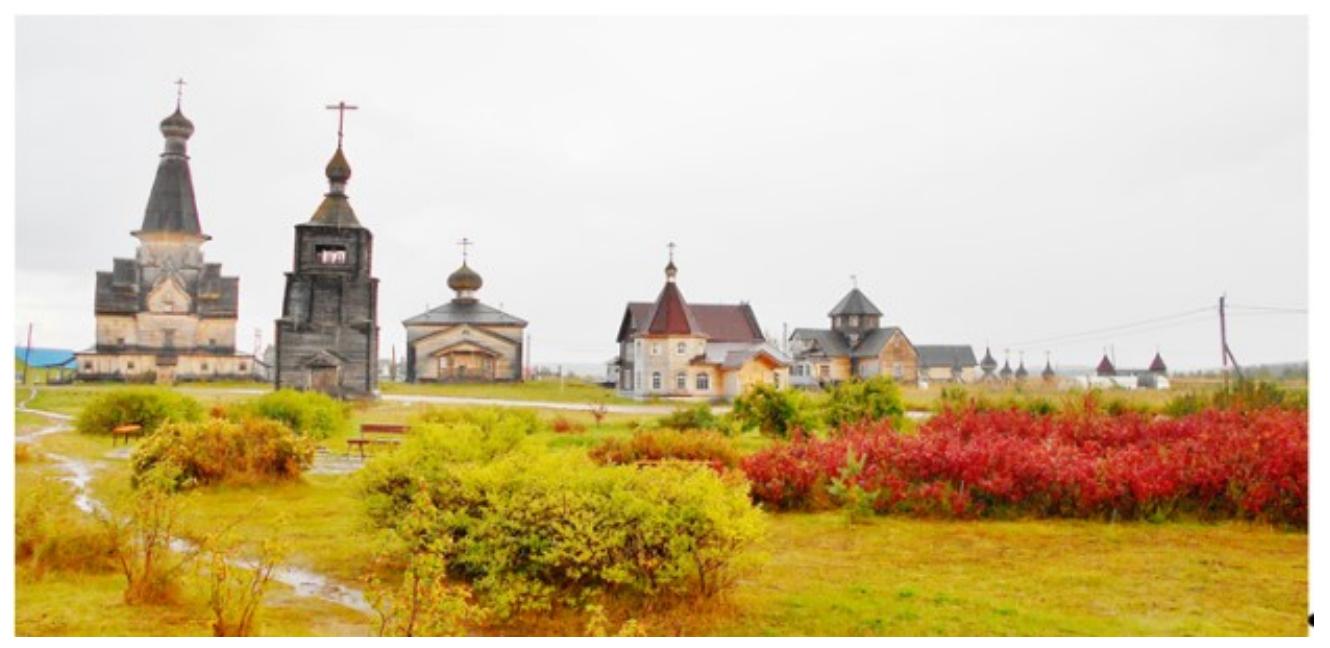

Рис. 5. Село Варзуга

По версии регионального отделения Русского географического общества (РГО) новые туристические тренды Мурманской области включают:

1. Военно-исторический туризм. Со времён Великой Отечественной войны и более позднего периода в Заполярье осталось много старых военных объектов. Несмотря на заброшенность, выглядят они очень живописно. Следует особо отметить Площадку 52. Это бывший секретный военный объект - хранилище ядерных боевых частей. Здесь обслуживали подводные лодки Северного флота. С начала 1990-х гг. ничего атомного здесь не осталось, а военную часть окончательно расформировали. Здесь в перспективе можно организовать музей истории подводных сил и проводить экскурсии по типу Балаклавского военного музея-бункера в Севастополе. Другой подобный объект, ещё ожидающий своих гостей, - порт Владимир в губе Уре. Это тоже база Северного флота, целый опустевший город. Для посещений готовят также и старую позицию ракетчиков, где планируется интерактивный проект.

2. Круглогодичный мототуризм. Мотоциклетный туризм - это очень перспективное направление. При содействии РГО и «Мотобухты» разработан тур по Мурманской области «Мотозаполярник». Это экологический и историкокраеведческий тур по красивейшим местам Кольского Заполярья. Маршрут протяжённостью 1157 километров рассчитан на семь-десять дней. Это будет настоящая Кольская «мотокругосветка».

3. Туризм историко-этнографический. Мурманская область знаменита и «местами силы», связанными с древними верованиями народа саами, тайной древней Гипербореи и старинными поморскими сёлами с уникальным деревянным зодчеством. Мурманское отделение РГО планирует маршруты и для любителей мистики, и для тех, кто готов погрузиться в историю региона. Многие такие места доступны только с опытными гидами. Например, на священное место саамов Сейдъявр стремятся многие гости региона, но этот маршрут совсем не прост, а для новичков даже опасен. Ловозёрские тундры очень отдалённое и суровое место. Планируется организация на Сейдозеро пеших и лодочных маршрутов с опытными гидами, которые помогут правильно 
себя вести в этом месте, расскажут самые интересные факты, покажут объекты, которые не всегда можно найти самостоятельно.

На юге Кольского полуострова, на северном берегу Кандалакшской губы Белого моря, находится старинное поморское село Порья Губа. В XVI в. оно было зажиточным: там находилось крупное усолье Соловецкого монастыря двадцать варниц. В советские годы село медленно умирало, было расселено и заброшено. Но обаяние места, старинного поморского поселения, там тем не менее можно почувствовать и перспективно использовать для организации экскурсионных познавательных туров и экспедиций.

4. Научный туризм. Кольский полуостров - место с уникальной северной природой. В Мурманской области расположено несколько заповедных территорий, в которых в последние годы активно развивается экологический познавательный туризм. Наблюдения за животными становятся более доступными не только специалистам, но и тем, кого влечёт дикая природа. Одно из таких направлений, очень популярных во всём мире, это бёрдвотчинг — наблюдение за птицами [29].

Одной из самых известных турфирм, развивающих научно-геологический и минералогический туризм на Кольском Севере, является «Норд Стоун», базирующаяся в Апатитах. Компания организует научно-познавательные турыэкспедиции без рюкзаков и палаток в Хибины совместно с учеными Кольского научного центра РАН. Самая популярная программа — «Синие горы и Белое море» по маршруту «Кировск - Кандалакша - Варзуга». Днем туристы передвигаются пешком налегке, а ночуют в гостиницах и гостевых домах со всеми удобствами.

Мурманская область вошла в «золотую» группу Национального рейтинга въездного туризма - 2019, заняв 18-е место из 85 и 2-е место среди регионов, входящих в Арктическую зону Российской Федерации, уступив только Республике Карелия. Составителями даны неформальные названия группам рейтинга. Связаны они с классификацией отелей и обозначениями уровня сервиса, принятыми во всем мире: «5 звезд», «4 звезды» и «3 звезды». Мурманская область вошла в группу с условным названием «5 звезд». Попадание в Топ-20 Мурманской области объясняется тем, что регион по большей части расположен за полярным кругом и сюда едут туристы со всего мира посмотреть на северное сияние. По критерию «Количество размещенных иностранных туристов за год на 1000 жителей данного региона» Мурманская область также вошла в Топ-20 и заняла 11-е место. Согласно данным, на 1000 жителей Кольского полуострова приходится 55 иностранцев, прибывших в Мурманскую область с целью туризма [30].

В настоящее время выбран вектор продвижения турпродуктов Мурманской области на рынки Китая и стран Юго-Восточной Азии. Благодаря активному развитию данного направления за последние годы произошло существенное увеличение притока туристов из Китая - до 19 тыс. человек в 2019 г. В 2017-2018 гг. резко возросло количество гостей из Таиланда - с 200 до 7000 чел. [17]. Хорошим маркетинговым ходом стал российско-таиландский фильм «Северное сияние любви», который снимался в Териберке. Основным брендом, привлекающим туристов в регион, является северное сияние.

Другими важными аттракциями Кольского Севера являются снег и саамская культура. Искусственно созданную аттракцию - саамскую деревню 
«Саам Сыйт» - посещают практически все иностранные туристы, прибывающие в регион в основном из стран Азии. Растущий с каждым годом турпоток, к сожалению, приводит к снижению качества сервиса и завышенным ценам. Российские туристы в своих отзывах часто жалуются на низкий уровень сервиса, дороговизну услуг и некачественное питание в саамской деревне.

В Мурманской области основными центрами этнографического туризма становятся: село Ловозеро (действует саамский музей, национальный культурный центр, проводятся летние и зимние саамские игры), поселок Умба (место проведения международного фольклорного фестиваля стран Баренцрегиона), аутентичная музейная поморская рыбацкая тоня Тетрино на берегу Белого моря и село Лопарское (экскурсантов принимает саамская родовая община). В пригородном мурманском поселке Молочный в 2019 г. организована небольшая экспозиция саамского быта под открытым небом. В селе Ловозеро предполагается создание этнографической деревни на берегу Поповского озера - места проведения международных саамских игр. В этнодеревне будет продемонстрирована культура и быт саамов и коми-ижемцев - коренных народов Кольского Севера.

Для дальнейшего роста числа гостей региональное правительство проводит системную работу по развитию инфраструктуры и внедрению новых каналов продвижения туристско-рекреационного потенциала на внутреннем и внешнем рынках. Так, совсем недавно проходила международная конференция «Горизонты Арктики» с участием туроператоров стран АзиатскоТихоокеанского региона, проявляющих наибольший интерес к Мурманской области. Региональное правительство совместно с представителями туристического сообщества проводит комплекс мероприятий по внедрению стандарта "China Friendly", ориентированного на особенности менталитета азиатских туристов [16].

В Мурманске в 2019 г. состоялось открытие туристского информационного центра (ТИЦ) Мурманской области. Главной целью создания учреждения стало объединение нескольких разрозненных городских и ведомственных туристских информационных центров в единую сеть. Объединенный региональный ТИЦ будет работать не просто как справочное бюро, а как маркетинговый центр для продвижения информации о северном регионе, о его жизни и развитии. Ожидается, что он станет инструментом продвижения Мурманской области как туристического объекта не только внутри страны, но и за рубежом. В ближайшем будущем в наиболее привлекательных отдаленных муниципальных образованиях Мурманской области планируется создание нескольких офисов регионального ТИЦ.

На данный момент в Мурманской области существует несколько маршрутов, которые предлагают туристам различный турпродукт. Например, людям предлагается гастрономический брендовый тур «Вкус Арктики», в котором туристы в течение трех дней путешествуют в Мурманск, Териберку и Ловозеро, пробуя местные арктические блюда из оленины, свежей рыбы и морошки. Арктическая кухня - это дополнительный бренд, который может привлечь туристов с помощью старых рецептов блюд поморов и саами.

Также существуют большие маршруты-конструкторы, в которых турист сам выбирает «точки притяжения», исходя из подготовленности и количества свободного времени. Можно выделить четыре потенциальные точки роста, 
которые способствуют развитию туризма и могут увеличить поток туристов в регион: водный, зимний, промышленный и паломнический виды туризма [31]. Кольский Север воспринимается как регион, где можно дольше других мест кататься на лыжах, снегоходах и наблюдать северное сияние. Перспективен также сноукайтинг, лучшее место для которого - Териберка.

В 2019 г. в регионе появилась новая ассоциация - «Союз туриндустрии Мурманской области», которая объединила интересы региональных турфирм и подняла на новый уровень туристические идеи, а также обеспечила дополнительное финансирование, которое будет использовано для развития туризма в Заполярье.

При наличии гигантского туристического потенциала Мурманской области необходимо повышать качество сервиса. Одна из ключевых задач установить профессиональный стандарт сервиса, удовлетворяющий запросы туристов. Будет развиваться система грантовой поддержки местных туроператоров. Планируется также распоряжение федерального правительства по закреплению в Баренцевом море участков для легальной ловли краба начиная с 2021 г., а это еще одна потенциальная точка роста туриндустрии [32].

Для организации коммуникации между всеми участниками турбизнеса и обеспечения максимального мультипликативного эффекта для всей экономики региона от туризма выбран кластерный подход при создании условий для развития данной сферы в Мурманской области. Функционирование туристического кластера на территории региона позволяет повысить эффективность использования его туристско-рекреационного потенциала.

Очевидно, что объединение сфер и направлений деятельности в региональный туристический кластер позволяет достичь синергетического эффекта в отрасли и обеспечить увеличение ВВП региона. Упор делается на формирование четырёх основных туристских кластеров - «Хибины», «Беломорье», Ловозерского и Печенгского. Сегодня к ним добавляются стихийно возникшие протокластеры «Мурманск» и «Териберка» [33].

В каждом кластере разрабатывается или уже разработан собственный узнаваемый бренд. Все они должны быть объединены под общим, так называемым зонтичным, брендом Мурманской области, который будет продвигаться на российском и международном рынках. В регионе будут создаваться брендовые туристические маршруты, развиваться новые виды турпродукта, такие как деловой и промышленный туризм. Перечень пилотных предприятий, которые потенциально могут стать флагманами развития промышленного туризма в Мурманской области, сформирован региональным комитетом по туризму. В этом списке такие компании, как «ФосАгро» (Кировский филиал АО «Апатит»), ПАО «Норникель» (Кольская ГМК), Кольская АЭС, «ЕвроХим» (Ковдорский ГОК) и АО «Олкон».

В перспективе - продвижение Мурманской области как туристического направления на новые рынки: в Европу (Германию, Испанию, Францию), Японию, Латинскую Америку и США. Рассчитанный на сегодня целевой показатель довести турпоток в область к 2025 г. до 557,4 тыс. человек в год [33, 34].

В Мурманской области имеются моногорода, для которых туризм за счет процесса реструктуризации может в ближайшее время стать главным фактором развития и диверсификации экономики на местах. 
Кировск. За последние годы поток туристов в Кировск и Хибины увеличился на $50 \%$ за счет модернизации туристской и спортивной инфраструктур (рис. 6).

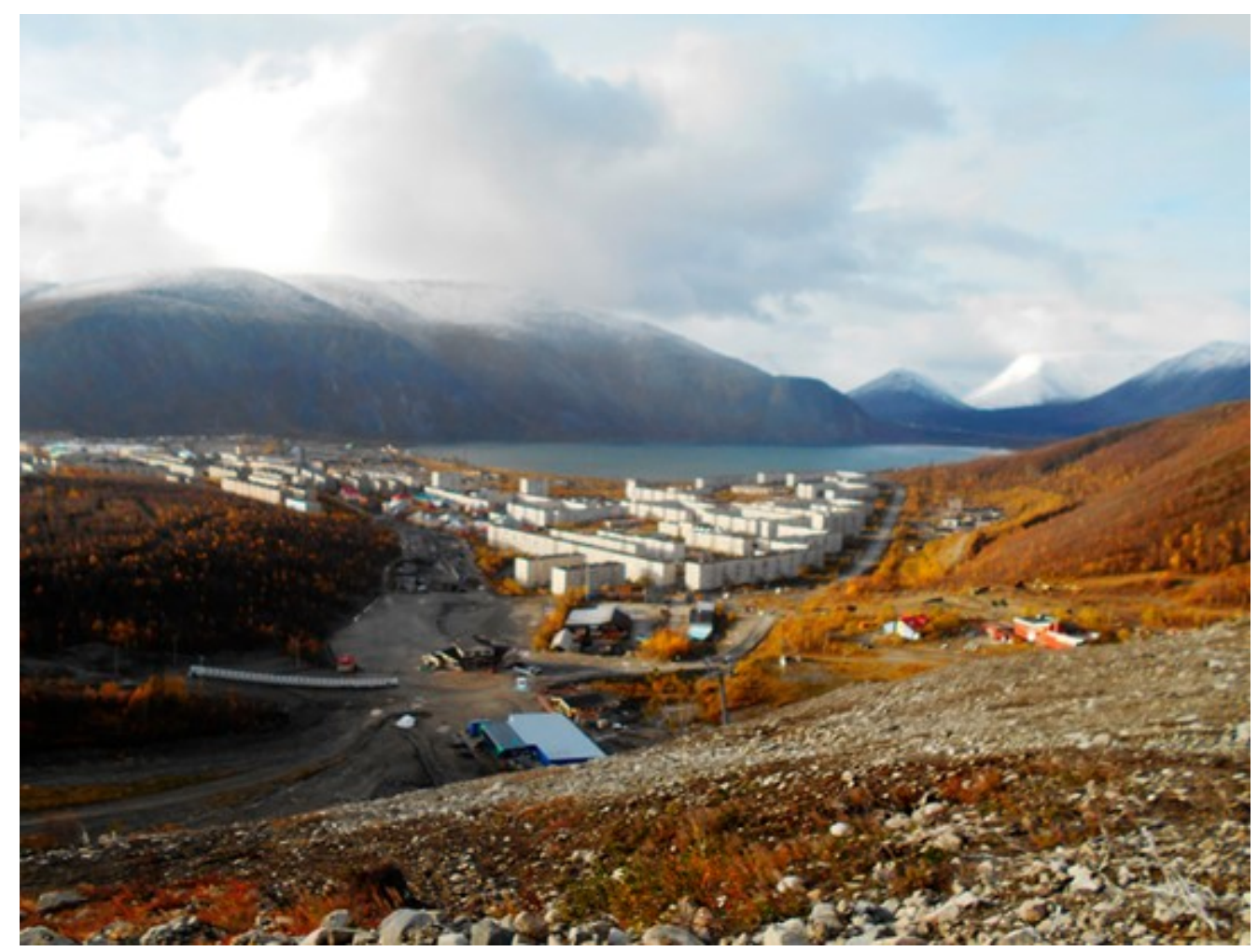

Рис. 6. Кировск

Импульс развитию туризма и уходу от монозависимости придает присвоение моногородам статуса территории опережающего социальноэкономического развития (ТОСЭР). С учетом того что в основном проекты ТОСЭР направлены на развитие туризма, предполагается увеличение турпотока в Кировск в два раза, создание около пятисот новых рабочих мест [16]. Кировская «Снежная деревня» - самый популярный объект показа в Мурманской области, занесена в «Книгу рекордов Гиннеса» как самое крупно е сооружение из снега в России. Дальнейшее развитие объектов инфраструктуры горнолыжного курорта (например, строительство панорамного ресторана на вершине горы, запуск работы национального парка «Хибины» и модернизация аэропорта «Хибины») позволит повысить туристскую привлекательность объекта и увеличить турпоток в Кировский регион до 120 тыс. человек в год.

Ковдор. В моногороде Ковдоре, втором городе области, получившем в 2019 г. статус ТОСЭР, начата реализация нового инвестиционного туристского проекта под брендом «Ковдор - столица Гипербореи». Инновационный проект предполагает создание гиперборейского туристского кластера на основе развития научно-экспедиционного и геолого-минералогического туризма, 
организации музейного парка, объектов инфраструктуры, пешеходных маршрутов к артефактам древней Гипербореи.

Кроме того, до 2022 г. планируется открыть новый международный пункт пропуска на границе с Финляндией Ковдор - Савукоски, что позволит преодолеть «тупиковое» транспортное положение Ковдора, сократить путь из соседней страны до других городов Заполярья и увеличить турпоток не только в Ковдорский район, но и в целом в Мурманскую область. Статус ТОСЭР позволит привлечь в город инвесторов, а также снизить уровень социальной напряженности. Благодаря новому статусу, пункту пропуска и проекту в Ковдорском районе появятся двести новых рабочих мест в сфере туризма, услуг, малого и среднего бизнеса [35].

Проект «Ковдор - столица Гипербореи» завоевал 1-е место во втором Международном маркетинговом конкурсе «РRОбренд — 2020» в номинации «Брендинг территорий». Это очередной серьезный шаг к развитию въездного туризма в Ковдорском районе, туристической инфраструктуры и малого бизнеса, а также трансграничного сотрудничества между Россией и Финляндией. Кроме того, это очередной весомый аргумент в решении вопроса о строительстве в Ковдоре пограничного перехода и установлении прямого автомобильного сообщения с Финляндией. Победа в конкурсе «РRОбренд - 2020» дает Ковдору право войти в сборник лучших мировых туристических практик с опытом создания и продвижения бренда «Ковдор - столица Гипербореи» [36]. К сожалению, в 2020 г. из-за пандемии Ковдор был закрыт для туристов.

Печенгский район играет важную роль в экономике региона как промышленный центр, он также важен благодаря своему приграничному расположению и богатой истории, что необходимо использовать для развития здесь туризма. Экотуризм, малолюдные направления и промышленный туризм основные направления для Печенгского района. Одним из объектов промышленного туризма может стать Кольская сверхглубокая скважина. Комплекс планируют восстановить, в том числе с привлечением денег из федерального бюджета, и сделать туристским объектом международного значения.

Новой точкой туристского притяжения намечено сделать и порт Лиинахамари, который будет принимать круизные суда и яхты. При этом у иностранцев появится возможность провести на территории Печенгского района до 72 часов без визы. Возросший турпоток потребует и новых мест размещения. Предполагается, что в Печенгском районе появится несколько базовых туристических лагерей и экоотелей с полной инфраструктурой. Уже известно, что это будет масштабный инвестиционный проект с качественной инфраструктурой, будут созданы рабочие места на территории присутствия компании «Норникель». На этап реализации проекта планируют выйти в 2025 г. [37].

В Лиинахамари будет построена туристская деревня на 900 номеров с сувенирными лавками, ресторанами и кафе, яхт-клуб с обустроенной гаванью, горнолыжный комплекс с канатными дорогами, морской вокзал с набережной, аквацентр. В федеральный проект будет инвестировано 12 млрд рублей [38].

Будут организованы экскурсии на промышленные объекты Печенгского района, природные тропы, расширены возможности для дайвинга и рыболовства. Модернизированный аэропорт Корзуново сможет принимать туристов. К 2022 г. планируется упростить режим кратковременного пребывания иностранных граждан. Создание коммунальной, транспортной 
и туристической инфраструктур позволит ежегодно привлекать в Печенгский район 300 тыс. туристов и дополнительные 40 млрд рублей в экономику региона, а также создать пятьсот новых рабочих мест [6].

Мурманская область участвует в двух приоритетных направлениях новой федеральной целевой программы по развитию туризма на период с 2019 по 2025 гг. — «Серебряное ожерелье России» и «Русская Арктика». В рамках создания инвестиционного проекта туристско-рекреационного кластера «Беломорье» на юге Мурманской области предполагается построить всесезонный спортивно-туристский комплекс [34].

Чтобы в полной мере реализовать все планы по развитию туризма, необходимы масштабная модернизация и строительство туристской и транспортной инфраструктур. Недостаток объектов инфраструктуры и значительный их износ — главные препятствия для развития туризма в регионе. Также вызывает тревогу неорганизованный туризм (прежде всего на нерестовых семужьих реках Терского района).

В рамках национального проекта «Экология» предусматривается организация нового национального парка «Терский берег», главная цель которого - спасение и сохранение семужьей реки Варзуги, в которой резко уменьшилось количество дикого лосося из-за браконьеров и сплавов неорганизованных водных туристов. Создание нового резервата в Терском районе позволит: поддержать биосферное равновесие, отрегулировать туристский поток, не допуская «дикого» туризма, а также сохранить поморский уклад жизни и традиционное природопользование местных жителей [39, с. 2].

Новый толчок развитию экологического туризма даст присвоенный Хибинам в 2018 г. статус первого в регионе национального парка. В 2019 г. он передан под управление ФГБУ «Лапландский заповедник». Национальный парк «Хибины» - будущий стратегический ориентир для привлечения туристов в регион. Сейчас наибольшей проблемой является вопрос финансирования из федерального бюджета, так как это территория федерального значения.

Эколого-туристический проект «Хибины для всех» в 2020 г. попал в число победителей первого этапа конкурса Агентства стратегических инициатив, направленного на создание туристическо-рекреационных кластеров и развитие экотуризма в России. В настоящее время идет работа над созданием мастер-плана, где будет расписано развитие Хибин как туристского кластера с акцентом на повышение транспортной и инвестиционной привлекательности, обустройство туристской инфраструктуры.

Главная задача проекта - создание системы поддержки малых предпринимателей, работающих в сфере экологического туризма и сувенирного производства на территории национального парка «Хибины» и в ближайших населенных пунктах. В рамках проекта создается Школа арктических гидовпроводников для ООПТ Мурманской области. Будут разработаны перспективные туристские пешеходные маршруты, в том числе и те, которые станут учебными для гидов. Так, например, один из маршрутов - экскурсия к бывшему молибденовому руднику на склоне горы Тахтарвумчорр.

Необходимо, чтобы территория Хибин получила дополнительное устойчивое развитие, новый стимул. Очень важно, что делается акцент на диверсификацию сезонности туризма в Хибинах, чтобы развитие получили летние предложения. Это будет способствовать тому, чтобы Хибинский кластер 
имел значительный вес в масштабах страны. Организаторы проекта рассчитывают до 2025 г. привлечь на территорию кластера более 1 млрд рублей инвестиций, в два-три раза увеличить турпоток, создать порядка ста рабочих мест, дать рост малому и среднему бизнесу, обеспечить налоговые поступления в бюджеты всех уровней в размере 4,5 млн рублей [40].

Ключевая идея проекта заключается в том, что Хибины - это домашние горы в шаговой доступности, которые должны стать школой всех видов горного туризма. Работы будут сосредоточены на определении допустимых экологических антропогенных нагрузок, особенно при ведении туристической деятельности, и на разработке рекомендаций по минимизации ущерба природе и местным сообществам. Посещать территорию национального парка «Хибины» местные жители смогут бесплатно, будут выделены зоны для сбора грибов и ягод.

Одной из ключевых проблем развития туризма является состояние дорожно-транспортной сети и активная деятельность нелегальных гидов. При формировании проектов прорабатывается вопрос улучшения дорожной инфраструктуры, позволяющей обеспечить устойчивую связь отдаленных районов с федеральной трассой Р-21. Также необходимо отметить, что преобладающие в регионе туристические группы из Китая зачастую обслуживают приезжие китайские гиды без российских лицензий, которые вытесняют с рынка местных гидов. В регионе не хватает официальных профессиональных гидов-проводников в экологических турах. В северных регионах России практически отсутствует базисная школа подготовки таких специалистов в отличие от соседних стран Северной Европы.

В Мурманской области также необходимо решение следующих актуальных проблем: бесконтрольный «дикий» туризм, загрязнение уникальных природных территорий. Проблема скопления и вывоза мусора остро стоит в природном парке на полуостровах Рыбачий и Средний. Решить проблему может введение туристического сбора в размере 500 руб. с машины при въезде в парк. На полученные средства можно организовать вывоз мусора, проложить дороги и экологические тропы для туристов.

Спортивная рекреационная рыбалка - один из главных туристических брендов Мурманской области. В середине мая на южных реках Варзуге, Пане и Кице начинается семужий сезон. Много лет назад на берегах этих рек организатор международного туристического бизнеса, колхоз «Всходы коммунизма», создал рыболовные лагеря. На рыбалку сюда ежегодно приезжает около тысячи состоятельных туристов. Колхоз работает с агентствами по всему миру. Их клиенты - это туристы из Великобритании, Франции и Испании, т. е. из стран, в которых в 2020 г. была тяжелая эпидемиологическая обстановка в связи с пандемией COVI-19. Следствием этого явился срыв весеннего рыболовного туристского сезона 2020 г. В связи с этим организатор переориентировался на российских клиентов.

Пакеты услуг, оказываемых внутренним и зарубежным рыболовным туристам, различаются. Иностранцы летают вертолетами, россияне ездят на своем автотранспорте. У иностранцев другие предпочтения в выборе направлений рыбалки, они выбирают рекреационную рыбалку по принципу «поймал - отпустил». Российские туристы используют принцип «поймал изъял». В случае отсутствия иностранных туристов, туроператор, колхоз «Всходы коммунизма», несет убытки по организации вертолетных туров, 
поскольку один час аренды работы вертолета стоит 200 тыс. рублей, а топливо обычно завозится с расчетом месячной рыбалки с ежедневными вылетами по пять часов [41].

Основная стратегическая задача в развитии заполярного туризма сохранить природу, обеспечить безопасность туристов и при этом достичь значимого экономического эффекта для муниципалитетов и региона. С развитием туризма можно также будет частично решить и острую проблему миграционного оттока населения из региона.

\section{1. Развитие экологического туризма на основе создания экологических троп и пешеходных маршрутов на Кольском Севере}

Приоритетным видом туризма в Мурманской области признан экологический (экотуризм). Его целесообразно развивать на ООПТ с целью регулирования и учета потока туристов. ООПТ все активней вовлекаются в туристическую деятельность Заполярья. Из их основных видов национальные (федерального значения) и природные (регионального значения) парки специально создаются для развития экологического туризма. В природных заповедниках, как правило, запрещена любая хозяйственная деятельность и сильно ограничена рекреация, так как основная задача заповедной территории - охрана природных комплексов. Недостаточное финансирование федеральных заповедников часто приводит к поиску дополнительных источников дохода. Одним из таких «средств выживания», например для Лапландского биосферного заповедника, является развитие регулируемого организованного экологического туризма.

Одним из главных компонентов развития экотуризма на ООПТ выступает создание экологических троп (экотроп). Они играют важную роль для регулирования допустимых нагрузок на охраняемые природные территории. Основная идея экотропы состоит прежде всего в экологическом обучении и воспитании тех, кто посещает охраняемые природные территории, в охране природы, а также в переводе потока посетителей в относительно безопасные для природы направления [42, с. 176].

Традиционно экотропы прокладываются в рекреационных зонах национальных и природных парков, заповедников, заказников, а также на неохраняемых территориях: в городских лесопарках, пригородной зоне отдыха и т. д. Для создания системы экологических троп необходимо соблюдать три главных критерия: привлекательность, доступность, информативность [43, с. 128]. Оборудованные по всем правилам безопасности экологические тропы, как правило, не оказывают негативного антропогенного воздействия на природные ландшафты.

В настоящее время в разных частях Мурманской области обустроено 18 экологических троп. Девять из них проложены на ООПТ, больше всего (пять троп) в Лапландском заповеднике. Пять экотроп организовано на территории населенных пунктов.

В Мурманске в 2018 г. был открыт первый экологический образовательный пешеходный маршрут вокруг Семеновского озера протяженностью пять километров. Для экологического просвещения активисты установили по пути экотропы знаки и стенды с информацией о местных природно-ландшафтных достопримечательностях и о необходимости бережного 
отношения к природе. В районе Семеновского озера можно увидеть сразу несколько природных зон: тундру, лесотундру, болота.

В одном из самых труднодоступных для туристов заповедников России, расположенном целиком в приграничной зоне, природном заповеднике «Пасвик», обустроен пешеходный экскурсионный маршрут. Экологическая тропа ведет на остров Варлаама, к дому-музею норвежского орнитолога Ханса Сконнинга. С помощью волонтеров Кольской ГМК реконструирован дом-музей, обустроена экотропа с возведением смотровой орнитологической вышки. «Пасвик» - это настоящий природный музей под открытым небом, здесь сохранились самые северные в Европе коренные сосновые леса. В перспективе возможно реализовать идею появления международной экологической тропы, проходящей по территории трехстороннего национального парка «Пасвик Инари» (находится на границе трех стран - России, Норвегии и Финляндии), получившего сертификат европарка [44].

Во время фестиваля «Териберка. Новая жизнь» в окрестностях арктического поморского села Териберка была организована экологическая тропа, которая ведет на птичий базар на берегу Баренцева моря. Тропа знакомит с уникальной экосистемой арктической тундры. Необходимо ее дальнейшее обустройство с упорядочением расстановки информационных стендов, установленных на маршруте довольно бессистемно, и наложением деревянных настилов через болотистую местность.

Самые известные обустроенные экологические тропы Кольского Севера проложены в Лапландском заповеднике. За последние два года здесь стало больше пешеходных маршрутов, на которых ведутся эколого-просветительские экскурсии. Появились новые объекты показа: визит-центр, ТИЦ и терем Деда Мороза.

Среди наиболее востребованных маршрутов - экотропа к старой усадьбе вдоль озера, тропа на гору Ельнюн, познавательная тропа «Лесная почемучка», пешеходный маршрут на смотровую площадку над ручьем Ельявруай. Новая тропа протяженностью 3,5 километров, оборудованная в 2017 г., проложена по берегу Чунозера и ведет к месту, где в 1930 г. располагался первый кордон Лапландского заповедника, где начиналась его история. На тропе проложены деревянные настилы, оборудованы подъемы и спуски, места для отдыха и обзорные площадки, установлены информационные стенды и биотуалеты. Важно, что экотропа стала доступней и для людей $\mathrm{c}$ ограниченными возможностями здоровья. По дороге путешественники получают информацию об особенностях северной природы, смене растительных поясов, повадках животных.

Компания «Норникель» активно участвовала в создании экотроп по двум направлениям: корпоративное волонтерство и программа «Мир новых возможностей». Кольская ГМК выделила около 5 млн рублей выигранного гранта на создание пешеходных маршрутов. Ключевым мероприятием экомарафона стал экологический слет, в результате которого волонтеры помогли оборудовать смотровую площадку и установили двадцать информационных щитов вдоль экотроп. Основными целями проекта являются экологическое воспитание и повышение культуры отношения к природе [45].

Инновационный проект «Познавательная тропа “Лесная почемучка"» часть этой программы: на интерактивном маршруте появились скульптуры животных, птиц, малые архитектурные формы и информационные щиты. В дальнейшем будут установлены еще несколько скульптур, запланировано 
освещение тропы, в процессе завершения - создание Лаборатории Бабы-яги и Колодца знаний.

Экологическая тропа «Нижняя Чуна — Чунозерская усадьба» длиной пять километров начинается от кордона ТИЦ «Нижняя Чуна» (официальный въезд в заповедник) на федеральной трассе «Кола» (1221-й километр) и ведет к Чунозерской усадьбе заповедника, где находятся два исторических музея и визит-центр. По маршруту маркированной тропы можно посетить саамский погост «Сийт», дендрарий, стоянки для отдыха, смотровые площадки, место для наблюдения за птицами «Глухариная горка» [46].

Маршрут «Восхождение на гору Ельнюн ІІ» высотой 590 метров и протяженностью около трех километров был заложен еще в 1930-е гг. и летом пользуется большой популярностью. Для удобства посетителей в зимнее время заповедник закупил специальное снаряжение - снегоступы. Данный маршрут интересен тем, что при подъеме на гору можно наглядно наблюдать высотную смену растительных поясов - тайгу, лесотундру и тундру. С вершины горы открывается панорамный вид на Чунозеро.

В настоящее время территорию Лапландского заповедника в разные сезоны посещают около 5 тыс. туристов в год, будут продолжаться работы по расширению и улучшению инфраструктуры. В ближайшей перспективе планируется увеличить протяженность оборудованных троп и открыть новую выставочную экспозицию, посвященную народу саами [47]. Обустраивать тропы заповеднику традиционно помогают волонтеры, многие из которых живут в Мончегорске и работают в Кольской ГМК.

В 2020 г. начато создание кольцевого маршрута «Лапландская кругосветка» от старой усадьбы заповедника с подъемом на гору Ельнюн I, переходом на гору Ельнюн II и спуском к чунозерской усадьбе (отправной точке). Протяженность маршрута составит 14 километров. Кроме того, планируется строительство нового терема Деда Мороза, а на южной границе заповедника со временем будут построены лесные домики для проживания туристов [46].

Новый инвестиционный проект предполагает обновление Чунозерской усадьбы - Вотчины Деда Мороза, строительство визит-центра заповедника под открытым небом. Предусматривается создание смотровых площадок, обустройство рекреационно-познавательных комплексов «Олений дом» и «Чум», строительство веревочного парка. Также в концепции заложено обновление исторического маршрута «Тян-Шанский - Крепс» и создание нового туристического пешего маршрута от Чунозерской усадьбы и водного маршрута из заповедника в национальный парк «Хибины», который находится под управлением Лапландского заповедника [48].

Вопрос с финансированием проекта еще предстоит решить. В заповеднике надеются, что смогут привлечь гранты и получить поддержку со стороны промышленных предприятий региона. Также необходимо решить проблему транспортной доступности. В настоящее время в Лапландский заповедник можно добраться только на автомобиле. Автобусные экскурсии осуществляются только из ближайших городов - Апатиты, Полярные Зори, Мончегорска. Представляется целесообразной организация однодневных общедоступных автобусных туров из Мурманска. 
В одном из самых северных в мире ботанических садов - Полярноальпийском ботаническом саду (ПАБСИ) - созданы две экологические тропы для ознакомления с местной флорой. Старейшая экологическая тропа Кольского полуострова проложена в середине 1930-х гг. и названа «Тропой географов». Этот познавательный пешеходный маршрут расположен на северо-восточном склоне горы Вудъяврчорр. Он дает возможность познакомить экскурсантов с представителями трех высотных поясов растительности Хибинских гор.

Экологическая тропа, которая поднимается практически на вершину горы Вудъяврчорр, проходит от смешанного таежного леса, через березовое криволесье до гольцовых арктических пустынь на плоской вершине, откуда можно видеть прекрасные панорамы Хибин. По пути экскурсанты знакомятся с уникальными растениями Кольского Севера. Вторая экологическая тропа заложена на предгорной равнине в окрестностях города Апатиты, на территории опытного участка ПАБСИ [49, с. 5].

В природном заказнике «Сейдъявр» в 2016 г. волонтерами из разных регионов России была проложена двухкилометровая экологическая тропа в районе Сейдозера с туристско-информационной навигацией и местами для отдыха, а в 2017 г. здесь была оборудована экотропа для людей с ограниченными возможностями здоровья. В этом труднодоступном районе Ловозерских тундр проходит популярный среди самодеятельных путешественников пешеходный туристский маршрут.

Любители пешего туризма в Кандалакшском районе могут выбрать четыре разноплановые экотропы: две эколого-краеведческие «Кандалакшский берег» и «Колвица», горную тропу на вершину горы Волосяной и городскую тропу здоровья. Трехкилометровый пешеходный маршрут «Кандалакшский берег» популярен среди местных жителей и туристов. Тропу обустроили в 2012 г., оборудовали указателями и табличками с описанием достопримечательностей. Начинается маршрут на Монастырском Наволоке, в черте города, проходит вдоль Кандалакшского залива по верхней тропе скалы Барыни и заканчивается в живописной губе Питкуль (рис. 7). Здесь, на полуострове, сохранился памятник археологии - каменный лабиринт.

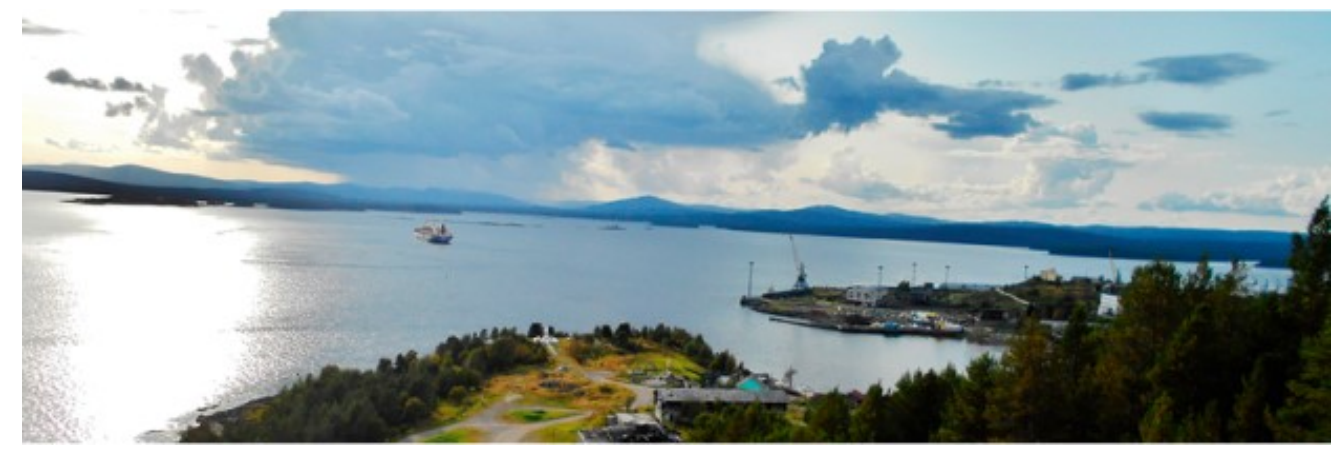

Рис. 7. Кандалакшский залив Белого моря 
В селе Колвица (28 километров от города Кандалакши) для туристов оборудована экотропа к колвицким водопадам протяженностью 2 километра. Начало тропа берет от моста, далее идет по сосновому бору вдоль левого берега реки Колвицы до водопада Черный Падун (рис. 8, 9). На тропе есть таблички с информацией о природных объектах, на склонах оборудованы ступеньки.

На горе Волосяной находится древнее капище, представляющее собой самое большое скопление священных камней саамов - сейдов. В Кандалакшском районе их более двухсот. Тропа начинается от сноупарка, в трех километрах от города, имеет протяженность почти пять километров, проходит по склону горы Волосяной, до самой ее вершины, откуда открывается панорама на залив, город и окрестности. Высота горы - 475 м над уровнем моря. На середине маршрута в 2018 г. построен инновационный туристский приют - ДубльДом со всеми удобствами и панорамным окном. Тропу также используют в качестве трассы для скоростного спуска на горных велосипедах. Велосипедисты оборудовали маршрут деревянными мостками и трамплинами.

Городская «тропа здоровья» начинается от навесного моста у гостиницы «Сполохи», проходит через сосновый лес по левому берегу реки Нивы, вверх по течению. Представляет собой пешеходную дорожку-терренкур, оборудованную местами для отдыха - скамейками и беседками. На тропе установлены информационные щиты и указатели, деревянные скульптуры и спортивные площадки. Изюминка тропы - белки, которых часто можно встретить [50]. В 2014 г. в Терском районе был реализован проект обустройства эколого-краеведческой тропы «Старинная поморская деревня Умба» протяженностью в 5,5 километров (рис. 10). Проект стал победителем всероссийского конкурса проектов «Культурная мозаика малых городов и сел», организованного благотворительным фондом Елены и Геннадия Тимченко ${ }^{1}$ в номинации «Пространство жизни» и получил грант на реализацию идеи. По всему пешеходному маршруту местными волонтерами и юными экологами были установлены информационные щиты, рассказывающие об истории поморского поселения, традиционных промыслах, флоре и фауне Терского берега. Также были оборудованы стоянки для отдыха туристов со смотровой площадкой. По тропе ежегодно проходит от 3 до 4 тыс. туристов [51].

В Терском районе также планируют обустроить пешеходный маршрут к петроглифам на островах озера Канозеро. Канозерские петроглифы находятся в одном из самых труднодоступных мест Кольского Севера, попасть к ним сейчас можно только на лодке или вездеходе. Проект музея под открытым небом «Петроглифы Канозера» - «Пешком в каменный век» стал победителем грантового конкурса «Музеи Русского Севера». Полученные средства пойдут на поиск инвестора и обустройство экологической тропы протяженностью 18-20 километров от автодороги Умба - Кандалакша до кордона на западном берегу озера Канозеро. Тропа будет доступна и для велотуристов, планируется установить на маршруте информационные щиты, указатели и места для отдыха [52].

1 Частный благотворительный фонд, содействующий благополучию целевых групп в российских регионах, с особым вниманием к небольшим городам и селам. 


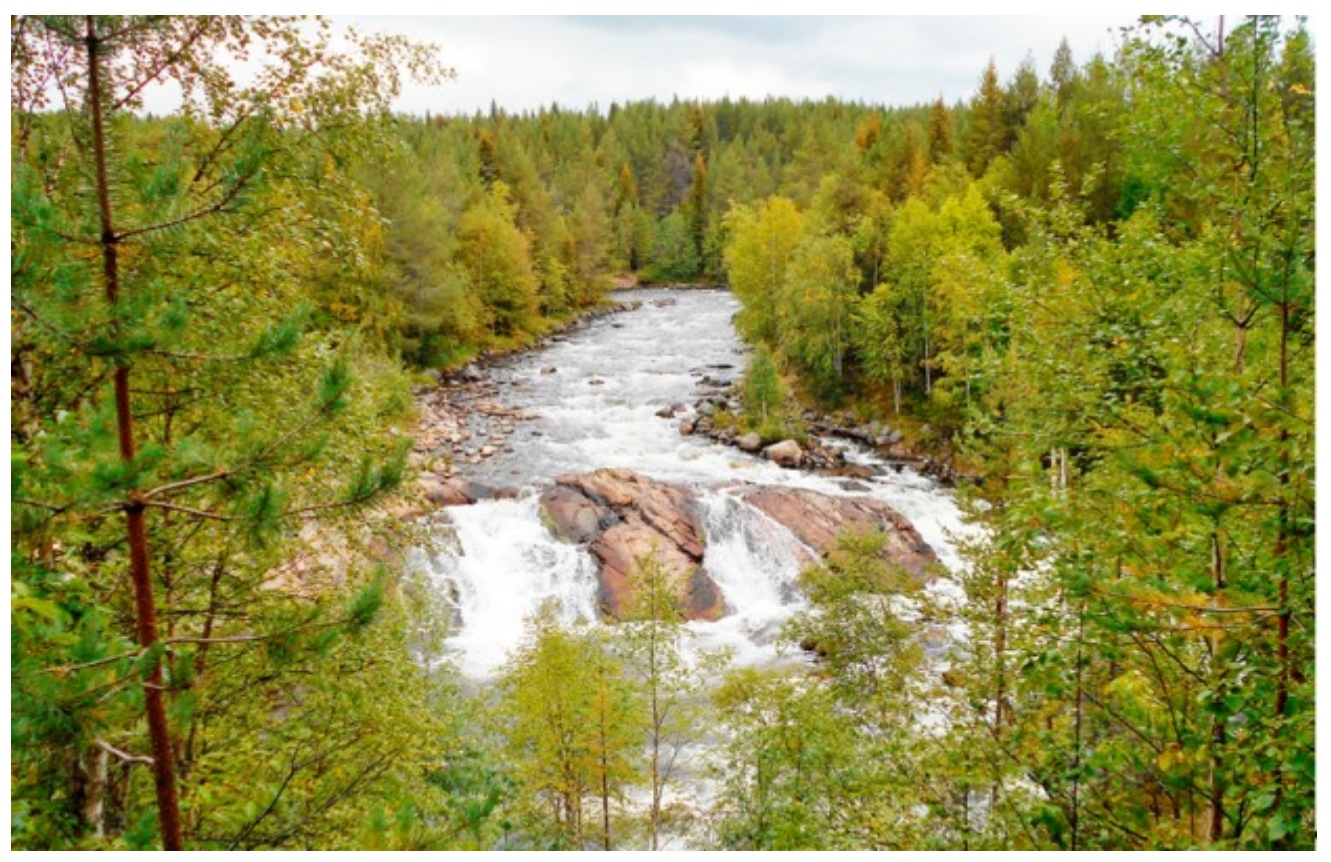

Рис. 8. Колвицкий водопад

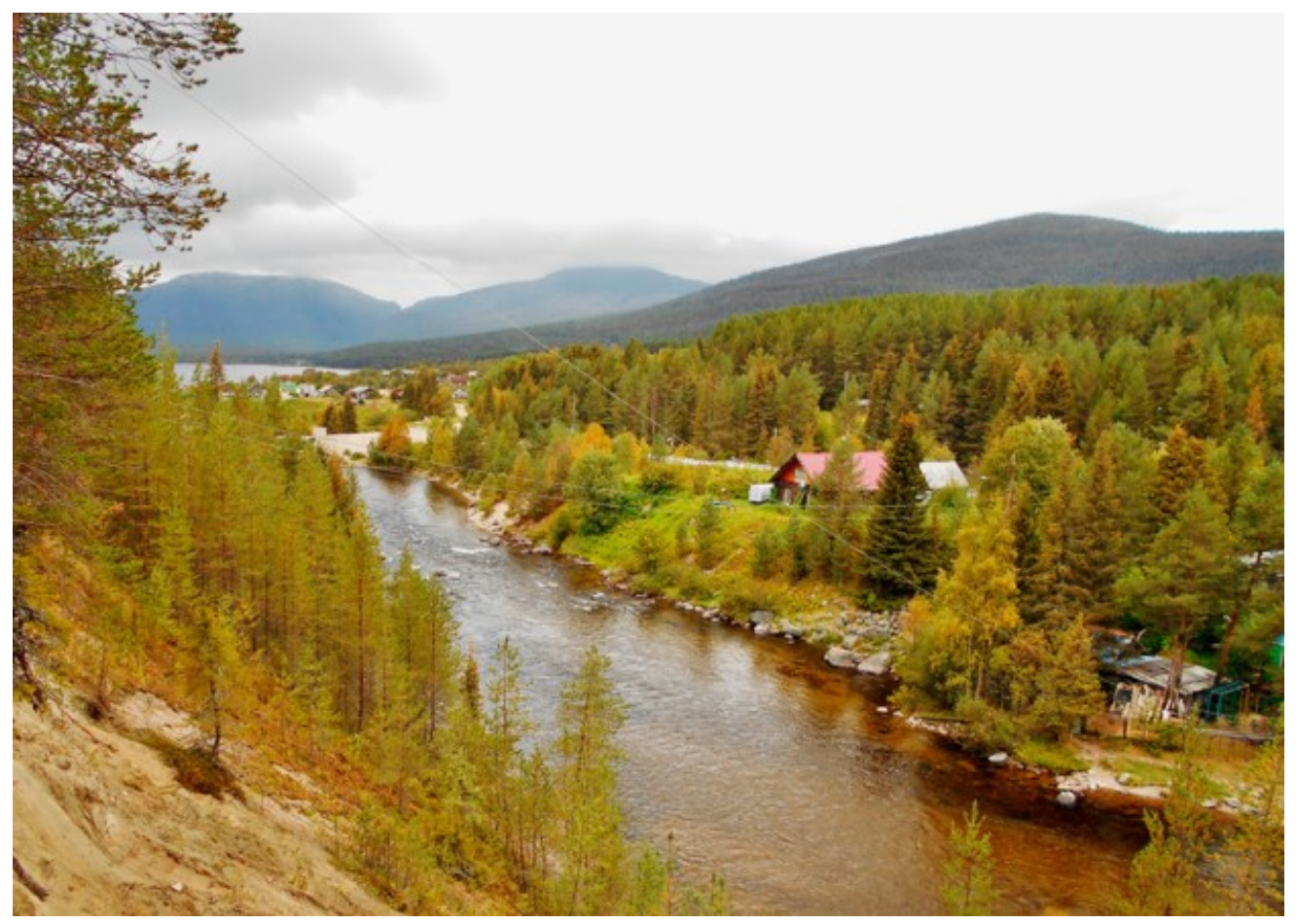

Рис. 9. Река Колвица 


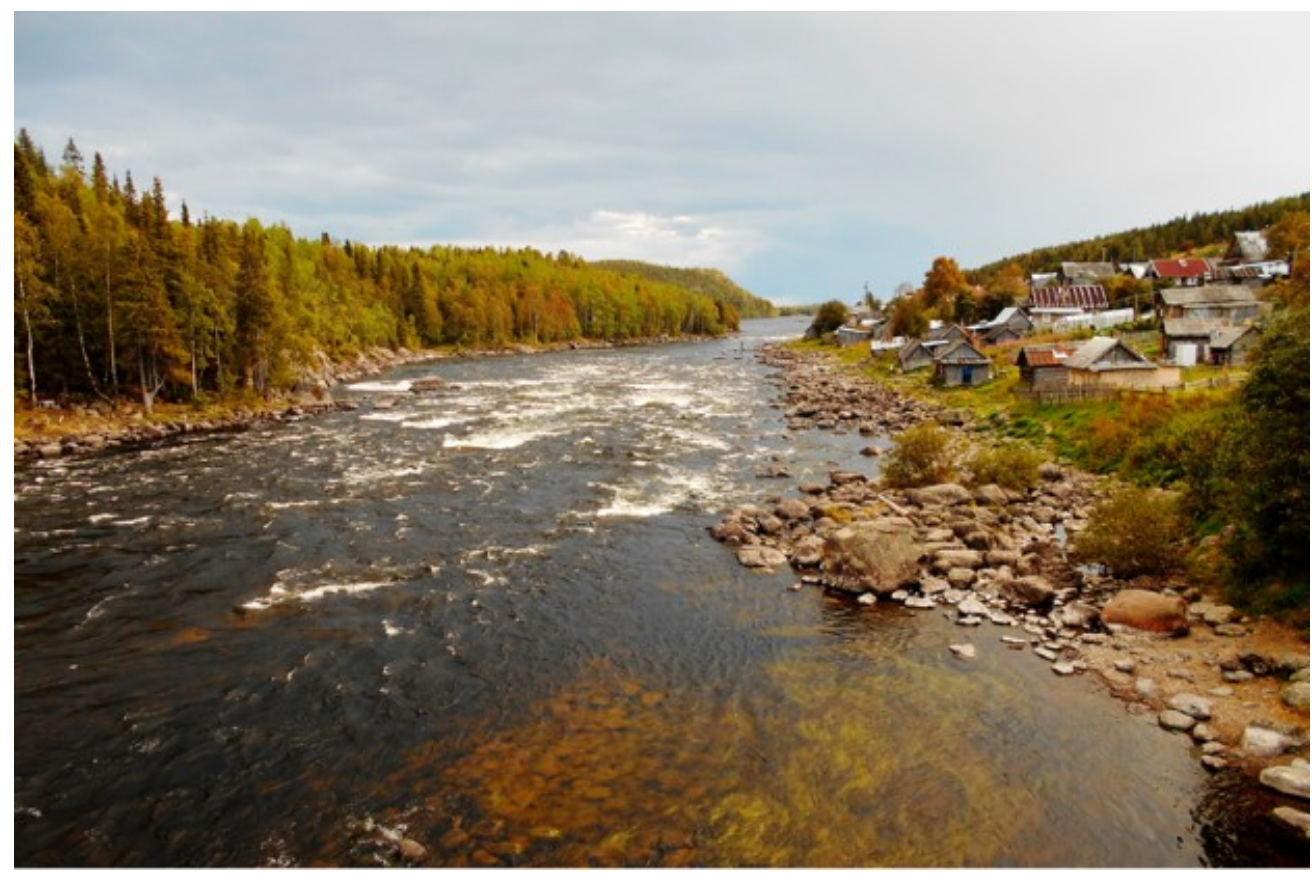

Рис. 10. Старая Умба

В 2019 г. в городе Полярные Зори в главной рекреационной зоне города, народном парке «Наш парк», при поддержке Кольской АЭС и Лапландского заповедника была обустроена экологическая тропа на берегу озера Пинозеро.

В Ковдоре, в районе горнолыжного комплекса «Варс», на горе Лысой в 2019 г. начато обустройство экотропы длиной 5 километров в рамках проекта «Ковдор - столица Гипербореи». Пешеходный экологический маршрут «По следам полярной совы» проходит через каньоны, озера и сейды и обустраивается силами местных энтузиастов без использования бюджетных средств. Экотропа в 2021 г. будет оснащена навигацией и информационными стендами.

В настоящий момент обустраивается трехкилометровая экологическая тропа в городе Апатиты, от микрорайона Белореченского до горнолыжной сопки Воробьиной. На склоне сопки будет обустроена смотровая площадка с видом на город. Тропу можно будет пройти зимой на снегоступах.

В ближайшее время планируется оборудование пешеходных туристских маршрутов в созданных ООПТ: национальном парке «Хибины» и природном парке на полуостровах Средний и Рыбачий (на базе реализации в 2019 г. концепции современной маршрутно-навигационной системы с автопередвижным визит-центром). Будет увеличиваться количество информационных стендов, аншлагов, костровищ, мест для уборки мусора с целью комфортного пребывания туристов на ООПТ. Планируется также организация экологической тропы вокруг озера Рогозеро (город Мурманск).

Инновационным направлением в развитии экологического туризма на Кольском Севере может стать организация национальной пешеходной тропы. Национальные тропы - это системы маршрутов самодеятельного туризма, которые оборудованы необходимой инфраструктурой. Можно предложить организовать 
такую тропу на территории Хибин и Ловозерских тундр с посещением особо популярного среди туристов священного озера саамов - Сейдозера, на берегу которого расположена скала с изображением великана Куйвы. Национальная пешеходная тропа должна быть протяженной, обустроенной, общедоступной для всех слоев населения и бесплатной для посещения. Тропу должны проложить опытные туристы и волонтеры по грунтовым дорожкам с заходом в наиболее красивые и интересные места региона.

Директор Лапландского заповедника Сергей Шестаков предлагает возродить один из старейших экологических маршрутов в России и мире Лапландскую тропу из Кандалакши в Колу. Основной маршрут задан. Его можно частично преодолевать пешком, частично на лодках, например от Зашейка до Оленегорска, или сплав по Коле от бывшего волока, от озера Пивнус, где проходит водораздел Белого и Баренцева морей, а где возможно передвигаться на машинах или внедорожной технике. Можно сделать радиальные выходы из него: на Терский берег, в национальный парк «Хибины», Лапландский заповедник, Мурманск, Териберку и Печенгский район. Сергей Шестаков считает: «Разработка стратегии или программы развития туризма в регионе на основе этой тропы объединила бы туроператоров. При этом можно заложить и инвестиции не только туркомпаний, но и бюджета... Выиграют от реализации этого проекта все!» [53].

Идея объединяющего стратегического ориентира для привлечения туристов в регион не новая. В настоящее время идет проработка создания экологической тропы «Путь Ломоносова», которая, как предполагается, пройдет по территории шести субъектов РФ (Москвы, Московской, Ярославской, Вологодской, Архангельской областей и Республики Карелия) [53].

\section{2. Териберка}

Териберка, получившая статус самого сурового поселка России, вошла в Топ-20 новых мировых туристических направлений 2016 г. по версии журнала National Geographic Traveller [54]. Поморское село Териберка получило широкую известность после выхода фильма «Левиафан», став популярным туристическим направлением. Начиная с 2015 г. Териберка - единственное место в России, куда можно приехать по автодороге к побережью Северного Ледовитого океана. После смягчения пограничного режима село стало более доступным для самостоятельных путешественников из разных стран мира (рис. 11, 12).

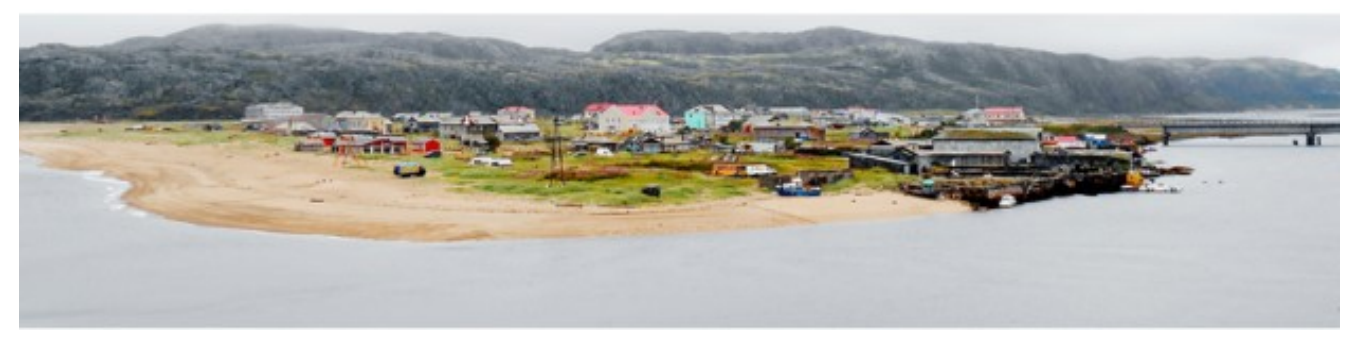

Рис. 11. Панорама села Териберка

По подсчетам местных гидов, зимой, на пике сезона, в Териберку ежедневно приезжает до тысячи туристов в день, весной, осенью - около 100 , 
летом - около 200 человек. За год поселок посещают порядка 40 тыс. туристов, при этом местный бюджет не получает от них доход [55]. Каждая вторая встреченная машина в Териберке из других регионов России. Здесь действует шесть объектов размещения, строится экоотель на 120 мест. В местных минигостиницах бронируют места за полгода, местные жители также зарабатывают на сдаче частного жилья. Зимой приезжают туристы из Китая, Таиланда и Кореи. Затем рыбаки, кайтеры, дайверы, музыканты, спортсмены, байкеры из разных стран. В последнее время в селе стало принято отмечать корпоративные мероприятия и важные даты крупных федеральных компаний. Кроме того, в Териберке летом стало проводиться много спортивных и культурно-массовых мероприятий.

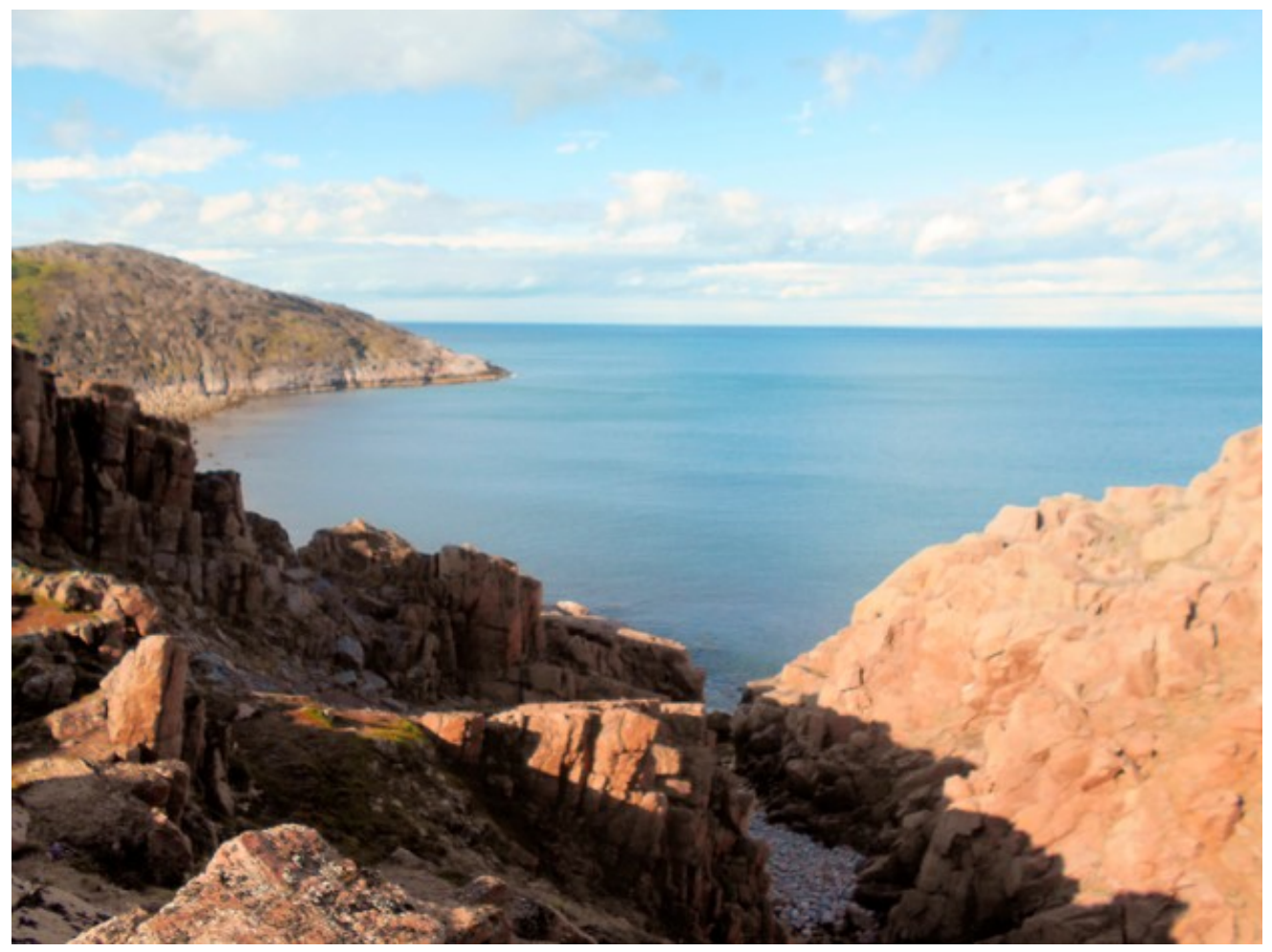

Рис. 12. Териберка. Баренцево море

Туризм стал селообразующей отраслью для Териберки, в которой прекратила существование фабрика по переработке рыбы, а вести прибрежный промысел рыбы на продажу местным жителям не разрешено (рис. 13). Здесь круглый год развиваются такие виды туризма, как морская прогулка и рыбалка, событийный и экологический туризм, сноукайтинг, наблюдение за северным сиянием, морскими животными и птицами. Основной турпоток в Териберку формируют китайские туристы, приезжающие зимой с целью увидеть северное сияние. Высокий сезон - китайский Новый год. 


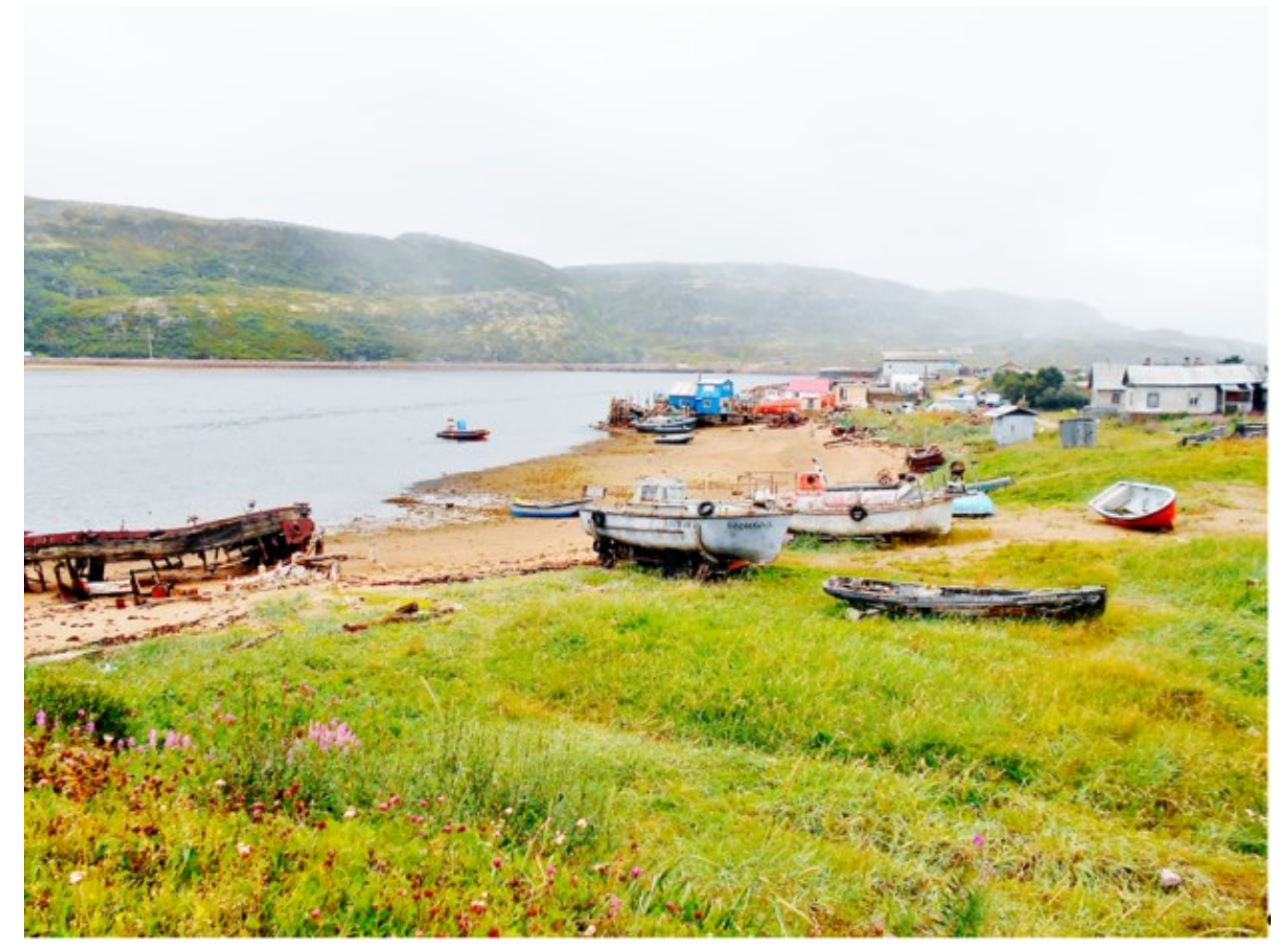

Рис. 13. Териберка. Сельский маломерный флот

Гастрономическим брендом Териберки, помимо рыбы, является белый хлеб из местной пекарни, за которым выстраиваются очереди. Свой вклад в популяризацию села привнес и впервые организованный в 2015 г. проектом «Большая Земля» и фермерским кооперативом «Лавка Лавка» фестиваль «Териберка. Новая жизнь». В 2019 г. двухдневный летний фестиваль посетило 5 тыс. человек [56]. На фестивале много внимания уделяется гастрономическим аспектам.

С точи зрения туризма Териберка - самое популярное село на Европейском Севере России, также оно входит в пятерку самых привлекательных в России (рис. 14). По официальным данным регионального правительства, в 2019 г. в поморском селе побывало 12 тыс. туристов из Китая и 7 тыс. из Таиланда. Неофициальные данные в разы превышают эти цифры.

Доход от китайских туристов невысокий. Путевка для туриста из Китая в Териберку по стоимости ниже, чем у российских туроператоров. Китайское турагентство набирает желающих, и гид выкупает эту группу. Сам гид платит несколько тысяч евро за то, чтобы сопровождать туристов в России. В будущем они могут здесь обзавестись своей инфраструктурой размещения, в области уже действуют китайские турбазы [55].

В 2020 г. в связи с пандемией количество китайских туристов в Териберке резко сократилось. Все коллективные брони из Китая были аннулированы. Вместо китайских туристов с начала года в Териберку стали приезжать туристы из Таиланда, Индонезии и Ирана. Тайских туристов привлекает сюда российско-таиландский фильм «Северное сияние любви», снятый недавно в Териберке. 


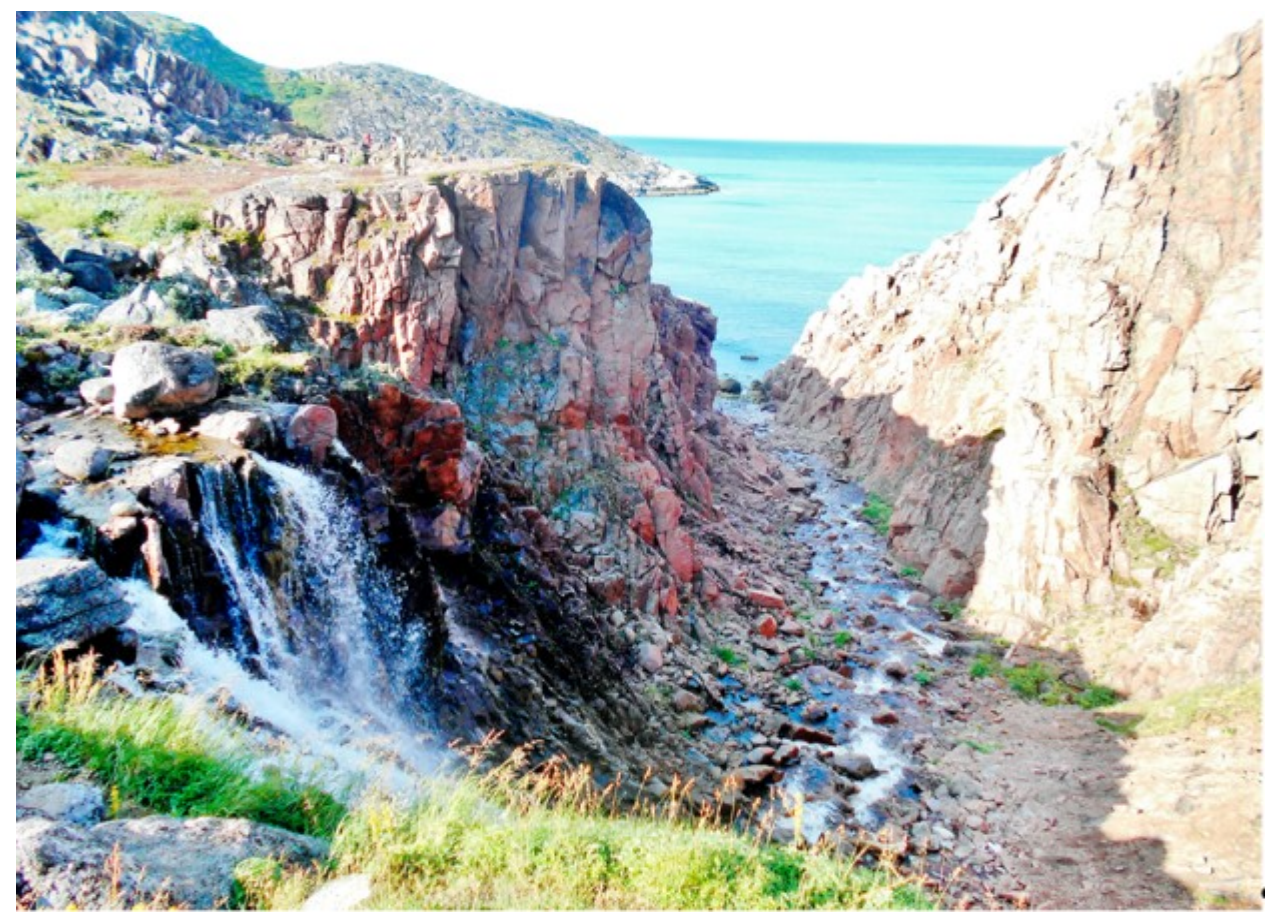

Рис. 14. Териберка. Водопад

Маловероятно, что туристские компании будут вкладывать средства в Териберку, пока в поморское село не будет построена безопасная дорога. Зимой Териберка часто бывает недоступной из-за снежных заносов и закрытия движения на мурманской автодороге. Нуждается в реконструкции участок дороги длиной в 40 километров от Териберки до серебрянской развилки.

Пока в Териберке наблюдается крайне хаотичное, несбалансированное развитие туризма. Преобладает «дикий», неорганизованный туризм. В высокий сезон отмечается сильная антропогенная нагрузка на арктический природный ландшафт, вытаптывается тундра. По пляжу и тундре туристы перемещаются на квадроциклах и автомобилях, оставляя после себя груды мусора.

В 2019 г. за сутки на выход в море заявлялось 520 лодок и маломерных судов, от двух до десяти человек в каждой. Итого в среднем тысяча человек в сутки выходило на морскую рыбалку. Объём вылова никто и нигде не учитывает, местный бюджет недополучает финансовые ресурсы. При этом приезжие рыбаки требуют от местных властей оборудованные парковки и туалеты. Любители рыбной ловли оставляют после себя рыбные отходы и мусор по всему побережью [55].

Власти Кольского района настаивают на том, чтобы взимать туристический сбор с гостей, приезжающих в Териберку. Но предприниматели (организаторы туров в основном из Мурманска и Москвы) отнеслись к этой идее без энтузиазма. По их мнению, власть не оказывает бизнесу в этом плане почти никакой поддержки, и они воспринимают туристический сбор как еще один вид поборов. По мнению же администрации района, ни один предприниматель 
в регионе не зарегистрирован и не платит налоги в бюджет, поэтому и не получает поддержки [57].

Организаторы инновационного проекта социально-экономического развития Териберки намерены разработать и запустить механизмы возрождения поморского поселения на основе организации событийных мероприятий, популяризации арктической северной кухни на основе местных продуктов, развития транспортной и туристской инфраструктур и традиционных поморских промыслов. Разработана концепция мастер-плана развития Териберки на основе создания экоэтнопоселения. Необходимо соблюдение баланса интересов местного населения и туристов. Реализация инвестиционных проектов посредством частно-государственного партнерства приведет к созданию в селе около 180 рабочих мест [58].

Необходимо также внести предложения по организации в Териберке и ее окрестностях системы туристской навигации и информации, обустройству маркированных троп к природным объектам показа (прежде всего к водопаду), созданию мест общественного питания (пока в селе работает только один дорогой ресторан), открытию сувенирных лавок и мини-музеев.

Для Териберки большое значение имеет легализация объектов туриндустрии. Это связано с доходами для села и местного бизнеса, а также с вопросами безопасности, так как нелегальные гиды могут рисковать жизнью и здоровьем туристов. Наблюдается паломничество туристов в Териберку, но при этом доходы местного бюджета составляют всего 1,3 млн рублей в год, в то время как средний уровень расходов иностранного туриста, приезжающего в Териберку, составляет 13 тыс. рублей в сутки, российского - 5 тыс. рублей [59]. В связи с ростом турпотока основная задача - пополнение местного бюджета для устойчивого развития и модернизации села, создания комфортных условий для пребывания гостей. Необходимо в первую очередь строительство автодороги до села от серебрянской дороги. Ученые ФИЦ КНЦ РАН подсчитали, что с учетом экологических аспектов предельная рекреационная емкость села определена на уровне 50 тыс. туристов в год.

Региональные власти вместе с экологами намерены к концу 2021 г. создать природный парк в селе Териберка. Главная задача проекта состоит в том, чтобы отрегулировать посещение территории и монетизировать растущий интерес туристов со всего мира. Одна из главных целей проекта - соблюсти баланс экологических и экономических интересов, внедрить лучшие мировые практики по формированию системы региональных туристических троп как точек притяжения туристов. По проекту планируется оборудовать пункт пропуска в природный парк и сформировать пул туристических компанийпартнеров, обустроить экологические маршруты и привлечь инвесторов для развития инфраструктуры в районе. 


\section{4. ЕВРОПЕЙСКИЙ СЕВЕР РОССИИ (РУССКИЙ СЕВЕР)}

\section{1. Туристский потенциал, основные проблемы, виды туризма и туристские маршруты}

С точки зрения развития туризма в Российской Федерации одно из самых выгодных положений занимает Европейский Север России. На территории региона расположено 22 исторических города, десять национальных природных парков, семь курортов, шесть архитектурноисторических музеев-заповедников мирового уровня, самый крупный (КириллоБелозерский) и самый древний (Валаамский) монастыри России, около 19 тыс. объектов культурного наследиях [60, с. 23-28]. В список всемирного культурного и природного наследия ЮНЕСКО занесено четыре объекта Европейского Севера - Ферапонтово, Соловецкий архипелаг, музей-заповедник «Кижи» и девственные леса Республики Коми (Печоро-Илычский заповедник и национальный парк «Югыд-Ва»). Валаамский архипелаг, карельские петроглифы (онежские и беломорские), Кенозерский национальный парк занесены в предварительный список всемирного наследия ЮНЕСКО.

Русский Север - это север России, европейская ее часть. Это понятие довольно размытое, не имеющее точного определения. Принадлежность того или иного региона к Русскому Северу не является общепринятой. Это район больше историко-культурный, чем административный или географический. Республику Коми российские географы предпочитают относить больше к Уральскому региону, нежели к Русскому Северу, а Мурманскую область к зоне Евро-Арктического региона. Большинство специалистов под понятием «Русский Север» подразумевают в первую очередь территорию Вологодской и Архангельской областей.

На формирование Европейского Севера как целостного района прежде всего оказало влияние географическое положение. Оно характеризуется несколькими важнейшими чертами, влияющими и на его природу, и на особенности заселения, и на развитие хозяйства:

Северное положение. Хотя район расположен в европейской части страны, большая часть его территории, за исключением Вологодской области, относится к зоне Крайнего Севера.

Приморское положение. В отличие от многих районов России Европейский Север широким фронтом выходит к огромной акватории Баренцева и Белого морей. Это в значительной мере определяет выгоды экономико-географического положения района. Крупные порты - Мурманск и Архангельск, возникшие на побережьях северных морей, играют важную роль в транспортной системе России и ее внешней торговле. Выход к морям влияет и на геополитическое положение района [60, с. 23-28].

Самыми доступными в транспортном плане регионами Европейского Севера являются Республика Карелия и Вологодская область (ночь езды на поезде из Москвы и Санкт-Петербурга). До Архангельской и Мурманской областей добраться можно на поезде за 1-1,5 суток или за 1,5-2 часа на самолете от двух столиц. Самым труднодоступным регионом является Ненецкий 
автономный округ (самый нетуристический регион России), до которого можно добраться только на самолете.

Самым дорогим регионом в плане предоставления туристских услуг является Мурманская область. Например, стоимость однодневной экскурсии на микроавтобусе из Мурманска по области может доходить до 3-5 тыс. рублей с человека, что в среднем в 2-3 раза дороже, чем стоимость аналогичной экскурсии из Петрозаводска или Архангельска.

Русский Север - чудом уцелевший островок исторической России, ведь Север избежал татаро-монгольского нашествия. Русский Север на протяжении многих веков сохранял древние обычаи, традиционную систему сельского селения и формы природопользования, облик старинных древнерусских сел и городов, исторические народные промыслы [61, с. 3-4]. Большинство сохранившихся памятников каменного и деревянного зодчества относятся к XVII-XIX вв.

Приветливое, радушное и гостеприимное местное население, душевный покой, отсутствие столпотворения и постоянной столичной спешки делают Европейский Север ещё более привлекательным для туристов. Уникальное природное наследие представлено разнообразием природных ландшафтов от горных массивов до бесконечной тундры, девственных лесов, изумрудных озер, водопадов, богатых рыбой ценных пород рек. На Русском Севере расположены крупнейшие озера Европы - Ладожское и Онежское, ставшие центрами особо популярного круизного туризма.

Европейский Север занимает исключительное место в историческом и культурном развитии России ввиду ярко выраженного проявления здесь исконно русских традиций, обычаев, наличия деревянной культовой архитектуры, традиционной живой культуры поморов, а также специфичности современного уклада жизни местного населения. Гармоничное сочетание естественного и антропогенного начал привело к формированию уникального типа особо охраняемых территорий — культурных ландшафтов.

Ввиду того что национальные парки занимают важное место в системе ООПТ благодаря природной и историко-культурной ценности, они стали одной из основных организационных форм охраны культурных ландшафтов природно-культурных территориальных комплексов, сформировавшихся в результате эволюционного воздействия природы и человека, его социокультурной и хозяйственной деятельности и состоящих из характерных устойчивых сочетаний природных и культурных компонентов, находящихся в тесной взаимосвязи и взаимообусловленности. Национальные парки Русского Севера стали одной из основных организационных форм охраны культурных ландшафтов, при этом они имеют колоссальный историко-культурный и экотуристский потенциал. В последние годы наблюдается тенденция перехода туристской деятельности в культурное пространство национальных парков (Кенозерский, «Русский Север»), на пространство культурных ландшафтов $[62$, c. 164-166].

Развитие туризма в северных регионах тормозят: фактор сезонности; большие пространства, которые не позволяют составлять динамичные и насыщенные турпродукты; суровый климат; однообразие турпродуктов; отсутствие долгосрочного планирования в туризме и планомерной работы по созданию привлекательного имиджа Русского Севера. 
Ключевыми проблемами северного туризма являются также отсутствие качественных средств размещения, невысокий уровень сервиса, плохое состояние дорожно-транспортной инфраструктуры, недостаток финансовых средств для создания новых объектов показа и реставрации памятников архитектуры.

Чтобы в полной мере реализовать все планы по развитию туризма на Севере, необходимы масштабная модернизация и строительство туристской и дорожно-транспортной инфраструктур. Недостаток объектов инфраструктуры и значительный их износ - главные препятствия для развития туризма.

В регионах Европейского Севера формируется сеть туристскорекреационных кластеров (ТРК) с целью расширения и повышения конкурентных преимуществ региональных турпродуктов. Инновационные инвестиционные проекты в сфере туризма должны привлечь в регион туристов, что обеспечит дополнительные инвестиции (в виде частно-государственного партнерства) в модернизацию инфраструктуры и дальнейшее устойчивое развитие уникальных территорий.

На современном этапе туризм активно развивается во всех регионах Европейского Севера, и наблюдается ежегодный рост турпотока. Основной туристский сезон - лето. Лишь два региона Русского Севера - Мурманская и Вологодская области - привлекают туристов также в зимний период и ранней весной. Высоким сезоном считаются новогодние каникулы и китайский Новый год, когда Великий Устюг, Кировск, Вологда, Териберка, Мурманск, саамская деревня «Саам Сыйт» принимают большое количество туристов. На Кольский Север в этот период приезжают в основном группы из Китая.

Формируемая на Русском Севере самая крупная в Европе сеть природных резерватов и архитектурно-этнографических музеев под открытым небом может рассматриваться как основной фактор для устойчивого развития туризма.

Виды туризма и туристские маршруты. Наиболее популярными туристскими маршрутами Русского Севера являются водные озерно-речные круизы по Волго-Балту (Череповец, Горицы-Кириллов, Вытегра), Ладожскому (Валаам) и Онежскому (Петрозаводск, Кижи) озерам. В Архангельской области по Северной Двине из Архангельска в Брин-Наволок и Северодвинск еще в 2019 г. выполнялись речные круизы на старейшем колесном пароходе России «Николай Гоголь», построенном в 1911 г. В круизном туризме требуют решения проблемы судовладельцев с речным регистром и отсутствием в регионах Русского Севера судов класса «река - море». Вследствие загрязнения и обмеления крупных судоходных рек (Сухоны, Северной Двины, Вычегды, Мезени) практически полностью прекращено круизное и пассажирское сообщение (кроме паромного).

Помимо водных круизов на Русском Севере активно развиваются следующие виды туризма: культурно-познавательный, горнолыжный, экологический, этнографический, сельский, событийный, деловой, рекреационная рыбалка, спортивный, религиозно-паломнический.

Наиболее перспективными межрегиональными туристскими маршрутами региона являются: мегапроект «Серебряное ожерелье России» (объединяет все регионы СЗФО), проекты «Ганзейские дороги России», «Дорогой Ломоносова», «Узоры городов российских». Инновационными видами туризма Европейского Севера являются морские арктические круизы, охота 
за северным сиянием, наблюдение за морскими животными, путешествия по местам съемок кинофильмов, гастрономический, промышленный, приграничный, геолого-минералогический, социально-ответственный туризм. Перспективен также outdoor туризм - отдых и досуг на свежем воздухе, развлечение и спорт одновременно.

Межрегиональные направления в рамках историко-культурного и туристского проекта «Серебряное ожерелье России» [63].

1. «Серебряное ожерелье России»:

Калининград - Псков - Великий Новгород - Вологда - Сыктывкар Нарьян-Мар - Архангельск - Мурманск - Петрозаводск - Ленинградская область (Лодейное Поле, Новая Ладога, Старая Ладога, Шлиссельбург) - СанктПетербург.

2. «Великий путь по Русскому Северу»:

Вологда - Великий Устюг - Сыктывкар - Инта - Воркута - Пым-ВаШор - Архангельск - Мурманск - Заонежье - Пудож - Медвежьегорск Шуньга - Толвуя (родина Зосимы Соловецкого) - Великая Губа - о. Кижи Повенец - Челмужи (Богоявленская церковь, место ссылки монахини Марфы, княгини Романовой, матери будущего царя Михаила) - Пяльма - Вытегра Вологда.

3. «Петровские города»:

Санкт-Петербург - Шлиссельбург - Новая Ладога - Лодейное Поле Санкт-Петербург - Петрозаводск - Архангельск - Вологда - Тотьма.

4. «Путешествие в Древнюю Русь»:

Великий Новгород - Изборск - Старая Ладога - Санкт-Петербург Олонец - Белозерск - Кириллов - Великий Устюг - Сыктывкар - Пустозерск.

5. «По следам варягов»:

Республика Карелия - Приозерск - Выборг - Санкт-Петербург Старая Ладога - Великий Новгород — Тихвин - Кириллов - Белозерск.

6. «Форпосты России»:

Калининград - Санкт-Петербург - Выборг - Приозерск Шлиссельбург - Старая Ладога - Санкт-Петербург - Олонец - Погранкондуши - Колатсельга - Кинерма - Кемь - Мурманск - Архангельск - Вологда Псков - Великий Новгород - Мурманск - Архангельск - Пустозерск; Изборск - Псков - Ивангород - Копорье - Санкт-Петербург - Выборг - Приозерск Республика Карелия (вдоль границы РФ).

7. «По святым местам»:

Санкт-Петербург - Псков - Великий Новгород - Тихвин - Вологда Республика Карелия (Муромский монастырь, Свято-Ильинская Волозерская пустынь) - Архангельская область (Соловецкие острова); Санкт-Петербург Новая Ладога - Старая Ладога - Тихвин - Белозерск - Кириллов - Вологда Тотьма - Великий Устюг.

8. «Живая вода Северо-Запада России»:

Москва - Череповец - Горицы - Вытегра - Мандроги - Лодейное Поле - Старая Ладога - Псков - Великий Новгород - Москва (в случае невозможности прохода судна по реке Волхов возможна организация автобусной экскурсии в Великий Новгород из Старой Ладоги); Санкт-Петербург - Лодейное Поле - Мандроги - Петрозаводск - Кижи - Кемь - Соловецкий острова; Архангельск - Онега - Сумпосад - Вирма - Беломорск - Кемь - Гридино Умба - Варзуга (поморские поселения Белого моря); Яренск - Сыктывкар Воркута - Пым-Ва-Шор (горячие радоновые источники). 
9. «Северные порты России»:

Санкт-Петербург - Беломорск - Кемь - Кандалакша - Мурманск Архангельск - Нарьян-Мар (Печорский порт) - Амдерма.

10. «Деревянное зодчество»:

Республика Карелия (Кижи) - Ленинградская область (Подпорожский район) - Вологодская область (Вытегра, Вологда) - Великий Новгород (музей деревянного зодчества «Витославлицы»); Архангельская область (музей деревянного зодчества «Малые Корелы») - Мурманская область (Варзуга, Терский район).

11. «Древо жизни» (древние вепсские поселения):

Республика Карелия (Прионежский район, Шелтозеро) - Ленинградская область (Подпорожский район, Винницы, Вознесенье) - Вологодская область (Бабаевский район).

12. «Коренные народы «Серебряного ожерелья России»:

Псковская область (деревня Сигово) - Республика Карелия (Прионежский район, Шелтозеро; Пряжинский район; Лахденпохский район) - Ленинградская область (Кингисеппский район, деревня Вистино (народы ижора и водь), Подпорожский район, Винницы, Вознесенье) - Мурманская область (поморы, терский район; саами, Ловозерский район) - Ненецкий автономный округ (село Красное, сельскохозяйственный производственный кооператив «Харп»).

13. «Города-призраки Севера»:

Корзуново (Мурманская область) - Чаронда (Вологодская область) Хальмер-Ю (Республика Коми) - Амдерма (Ненецкий автономный округ).

Для краткой характеристики региона в европейском масштабе может быть использован лозунг «Русский Север - это дикая природа и водные просторы Европы». Именно в этом заключен основной фактор для развития экологического туризма - сектора наиболее быстрого роста туризма.

Экологический туризм в основном развивается в национальных парках «Югыд-Ва» (Республика Коми), «Паанаярви», «Калевальский», «Водлозерский» (Республика Карелия), «Кенозерский», «Русская Арктика», «Онежское Поморье» и «Водлозерский» (Архангельская область), «Русский Север» (Вологодская область). Водлозерский национальный парк расположен на территории сразу двух регионов Европейского Севера. Любые формы регулируемого туризма (особенно экологический и эколого-культурный) являются предпочтительными видами деятельности для большинства национальных парков.

Массовые потоки самодеятельных туристов предпочитают в основном сплавы по рекам и водоемам Карелии и Мурманской области, пешеходные и лыжные походы по Хибинам.

Этнографический туризм. Европейский Север - настоящий заповедник традиционной народной культуры мирового значения. Здесь представлены культуры различных народов и этнографических групп: саамов, поморов, ненцев, коми, карелов, вепсов, финнов, русских, что предопределяет широкие возможности для развития этнографического туризма.

С точки зрения сохранения коренных народов и живой традиционной культуры Русского Севера намного эффективнее развивать малозатратный культурный и природный туризм малых форм, что открывает возможности для поиска средств к существованию по всему региону и не требует больших инвестиций. Начальным импульсом к реализации новой идеи могло бы стать создание инновационных ядер на основе этнокультурных центров 
и этноприродных парков в разных уголках Европейского Севера. Интеграция культурного наследия в локальные зоны этнокультурного центра позволяет наилучшим образом сочетать идею сохранения с идеей возрождения уникальной территории [64, с. 59-86].

Музейный этнопарк под открытым небом - объект культурного туризма, интерпретирующий диалоги разных культур через аутентично созданные этнодворы, в которых туристы могут проживать и осваивать технологию изготовления продукции народных художественных промыслов у местных мастеров.

В настоящее время на Европейском Севере действует четыре архитектурно-этнографических музея-заповедника под открытым небом: крупнейший в России - «Малые Корелы» в Архангельской области, «Кижи» в Карелии, «Семенково» в Вологодской области, финно-угорский этнопарк в Республике Коми (село Ыб).

На Кольском полуострове основными центрами этнографического туризма становятся село Ловозеро (место компактного проживания саамов и коми-ижемцев), саамская деревня «Саам Сыйт», поселок Умба, музейная поморская тоня Тетрино, село Лопарское.

Привлекает туристов также сохранившаяся культура старообрядцев в исторических поселениях Кимжа (Архангельская область) и Усть-Цильма (родовые дома и место проведения фольклорного фестиваля «Усть-Цилемская горка») в Республике Коми. Представляют интерес также Олонец (самый карельский по национальному составу город Карелии), поселок Калевала (родина эпоса «Калевала») и национальное село Ижма (место компактного проживания коми-ижемцев в Республике Коми).

В деревнях Карелии, Вологодской и Архангельской областей активно развивается сельский туризм. Перспективен на Европейском Севере и промышленный туризм (Череповец, Кировск).

Паломнические православные туры ориентированы в основном на Валаам, Соловецкий архипелаг, Кирилловский район, Вологду, АнтониевоСийский монастырь, православные монастыри Республики Коми. Курортнооздоровительный туризм получил распространение в республиках Карелия (Марциальные Воды), Коми (курорт Серегово), Архангельской области (курорты Беломорье, Красноборск, Сольвычегодск), Вологодской области (Леденгский курорт, Тотьма).

Морской арктический туризм активно развивается в Мурманской и Архангельской областях. Рекреаџионная рыбалка получила распространение в основном на семужных реках Кольского полуострова. Горнолыжный туризм популярен в Мурманской области (Кировске, Мончегорске, Мурманске и Полярных Зорях). Деловой бизнес-туризм получил развитие в крупных городах с развитой гостиничной инфраструктурой (Мурманске, Петрозаводске, Архангельске, Вологде, Череповце и Сыктывкаре).

Большую популярность среди туристов набирает гастрономический туризм. Все регионы Европейского Севера включены в федеральный проект «Гастрономическая карта России» с целью популяризации местных кулинарных брендов и традиций. Туристы могут попробовать такие блюда традиционной северной кухни, как поморские шаньги, карельские калитки, рыбники, уху из семги, пироги с ягодами, оленину, треску. Например, в Мурманской области 
сформирован зонтичный бренд «Сделано в Арктике» для поддержки производителей арктической кухни. Кольский Север сможет составить конкуренцию по блюдам из оленины другим северным регионам, а по морепродуктам - Дальнему Востоку [65].

\section{2. Республика Карелия}

В Республике Карелия благоприятно сочетаются выгодное транспортногеографическое положение и сохранившийся природно-ресурсный потенциал, богатое культурно-историческое, этнографическое и религиозное наследие. Это достаточно уникальное сочетание различных туристско-рекреационных ресурсов создает хорошую основу и перспективу для развития различных видов и форм туризма.

В республике выделены шестнадцать этнокультурных исторических территорий с сохранившейся историко-культурной средой, сосредоточено более 4500 объектов культурного наследия.

Туризм в Республике Карелия признан приоритетной отраслью экономики, которая приобретает все большее значение в развитии всего экономического потенциала республики. Карелия традиционно удерживает лидирующие позиции среди российских регионов по туристской привлекательности.

Туристический поток в Республику Карелия на протяжении последних лет стабильно растет. Доля организованных туристов в общем числе посетителей составляет около 60 \% (800 тыс. чел. в 2018 г.). Общий объем потока посетителей, включая экскурсантов, в 2018 г. составил 1320 тыс. человек. Среди центров туризма по посещаемости лидируют: горный парк «Рускеала» 350 тыс. туристов, музей «Кижи» - 220 тыс. чел., заповедник «Кивач» 120 тыс. чел., остров Валаам - 100 тыс. чел. (рис. 15, 16) [66, 67].

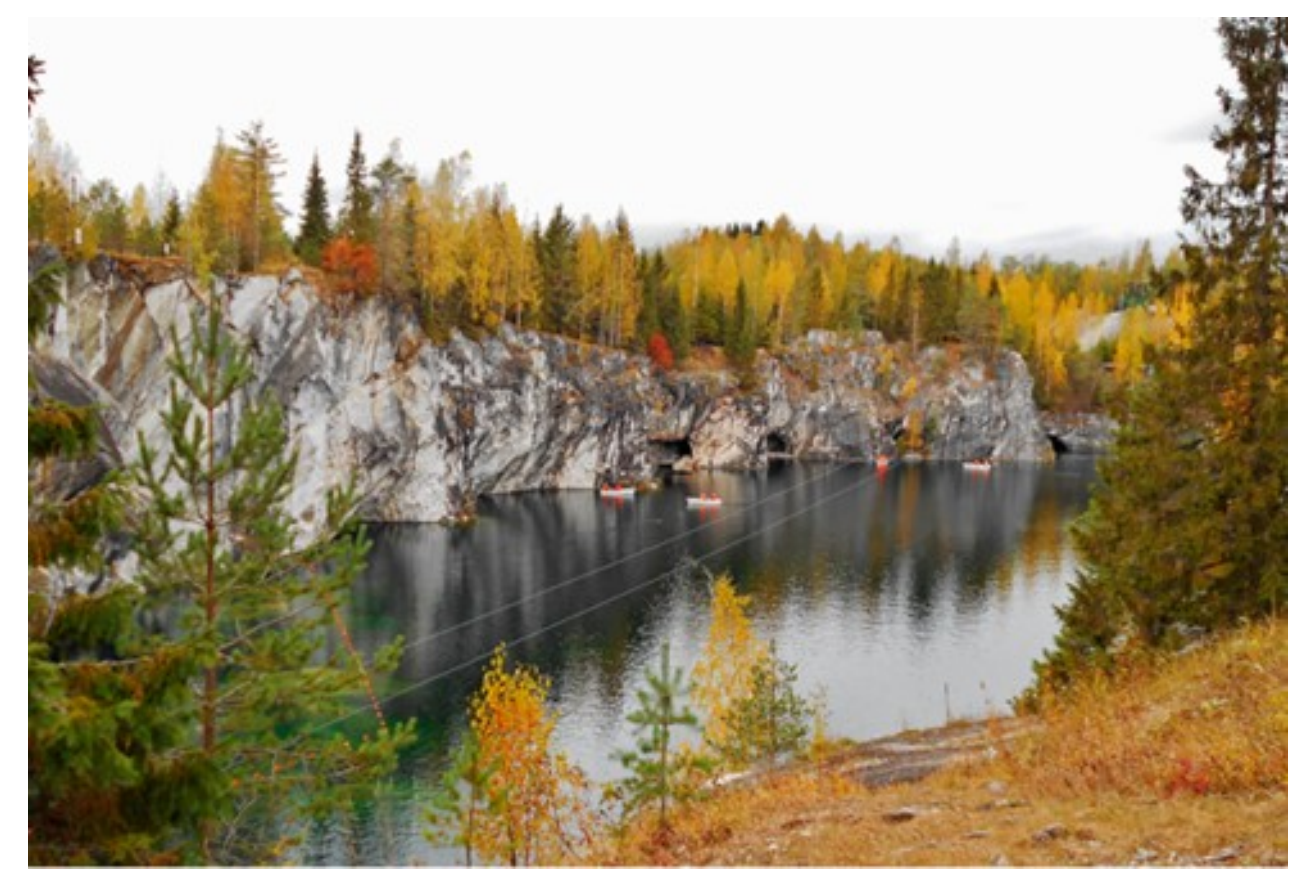

Рис. 15. Горный парк «Рускеала» 


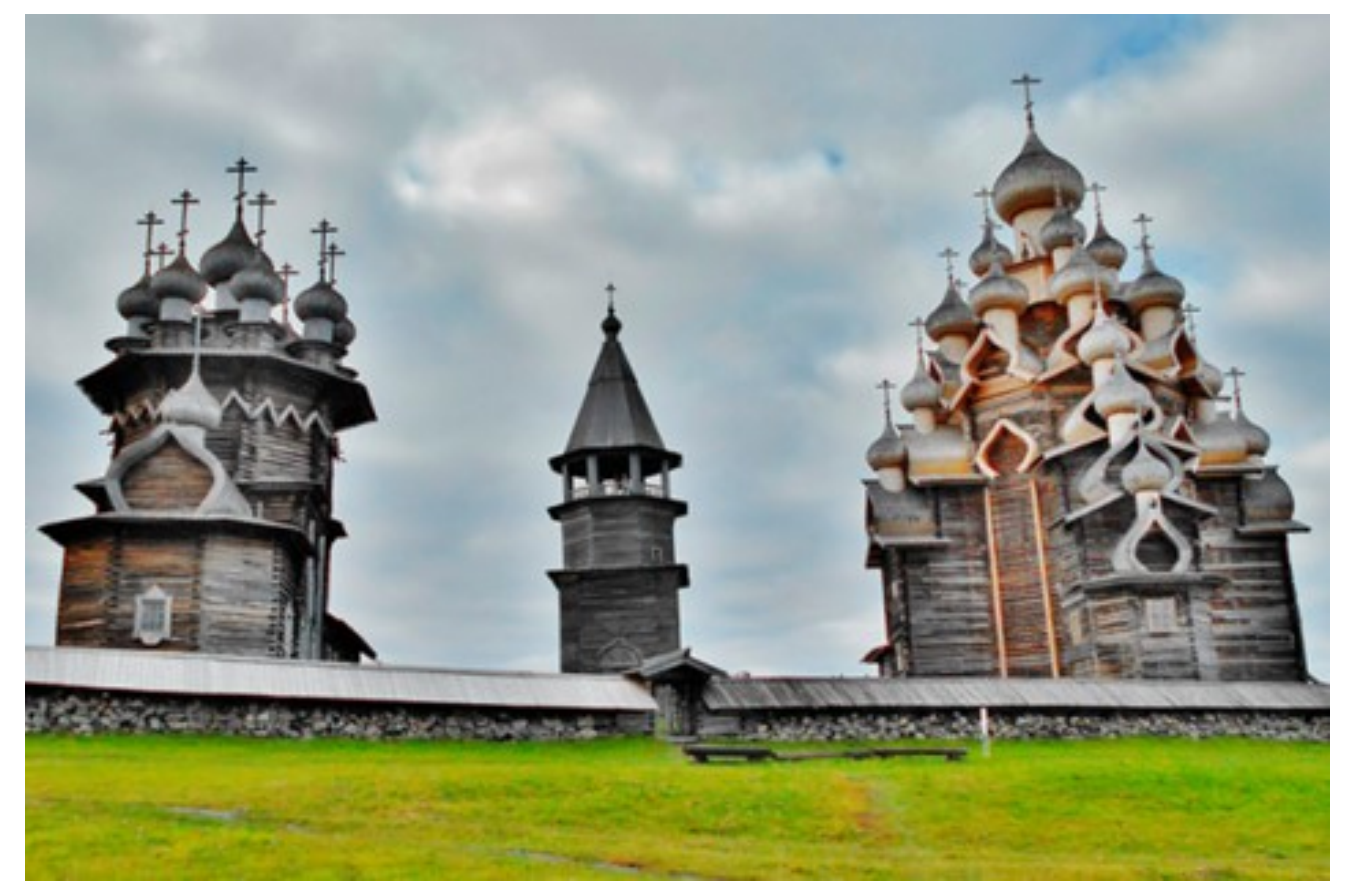

Рис. 16. Музей-заповедник «Кижи»

Туристическая отрасль Карелии в последние три года имеет лидирующие темпы роста среди всех отраслей региональной экономики. По итогам 2019 г. турпоток организованных туристов составил 830 тыс. человек, a закрытые границы в условиях пандемии и относительно спокойная эпидемиологическая ситуация весной и летом 2020 г. сделали Карелию ещё более привлекательной для туристов. По данным Управления по туризму Карелии, только в июле и августе 2020 г. в республике побывало 350 тыс. человек, в то время как за полноценный летний сезон 2019 г. - на 100 тыс. меньше, рост турпотока составил порядка 40 \%, а по итогам 2020 г. республику посетило 790 тыс. человек (табл. 4). Посещаемость горного парка «Рускеала» выросла практически вдвое, а в соседней Сортавале в гостиницах не было свободных мест. Весь летний туристский сезон загрузка отелей Петрозаводска и Приладожья достигала 100 \%, к осени ажиотажный спрос спал, но на новогодние праздники власти Карелии вновь ждали большое количество гостей.

Туристский поток в Республику Карелия [67]

Таблица 4

\begin{tabular}{|c|c|c|c|}
\hline 2017 г. & 2018 г. & 2019 г. & 2020 г. \\
\hline \multicolumn{4}{|c|}{ Объем организованного туристского потока, тыс. чел. } \\
\hline 780 & 800 & 830 & 790 \\
\hline
\end{tabular}

В структуре валового регионального продукта доля туризма составляет 4-5 \%. В структуре общероссийского объема туристских услуг доля республики составляет более $3 \%$ [66]. 
Всего туристский комплекс республики способен обеспечить до 3 млн ночевок в год в комфортабельных средствах размещения. Однако при стабильном росте количества посещающих регион туристов на сегодняшний день недостаточно гостиниц, особенно в бюджетном, а также высоком и премиальном ценовых сегментах.

Особенностью Карелии является неравномерность распределения туристского потока по регионам республики из-за различного уровня развития туристской инфраструктуры и наличия туристских ресурсов. В настоящее время основная туристская нагрузка приходится на два района - центр и Северное Приладожье, где расположены два всемирно известных аттрактивных центра туризма - музей-заповедник «Кижи» и Валаам, а также столица Карелии Петрозаводск, которые являются самыми посещаемыми объектами республики. Карельский туристский поток имеет ярко выраженную сезонность, так как приходится в основном на три летних месяца. В силу данных обстоятельств возникает проблема превышения предельной рекреационной нагрузки на основные туристские объекты (Кижи, Валаам) [68].

Туризм Карелии представляет собой интегрированный вид экономической деятельности, которая позволяет при сравнительно небольших капиталовложениях обеспечить экономически рентабельное использование и воспроизводство местных туристских ресурсов и потенциала. Поэтому для условий Карелии правомерен выбор туристского направления развития региона в качестве приоритетного по отношению к ее промышленному развитию.

Стремительный рост турпотока в приграничный горный парк «Рускеала» дал региону синергетический эффект, объединив вокруг проекта порядка трехсот человек - представителей малого бизнеса и туристических компаний (рис. 17). Главное здесь — не нарушить существующий природный баланс, не превратить заповедное место в типовой массовый парк аттракционов [56].

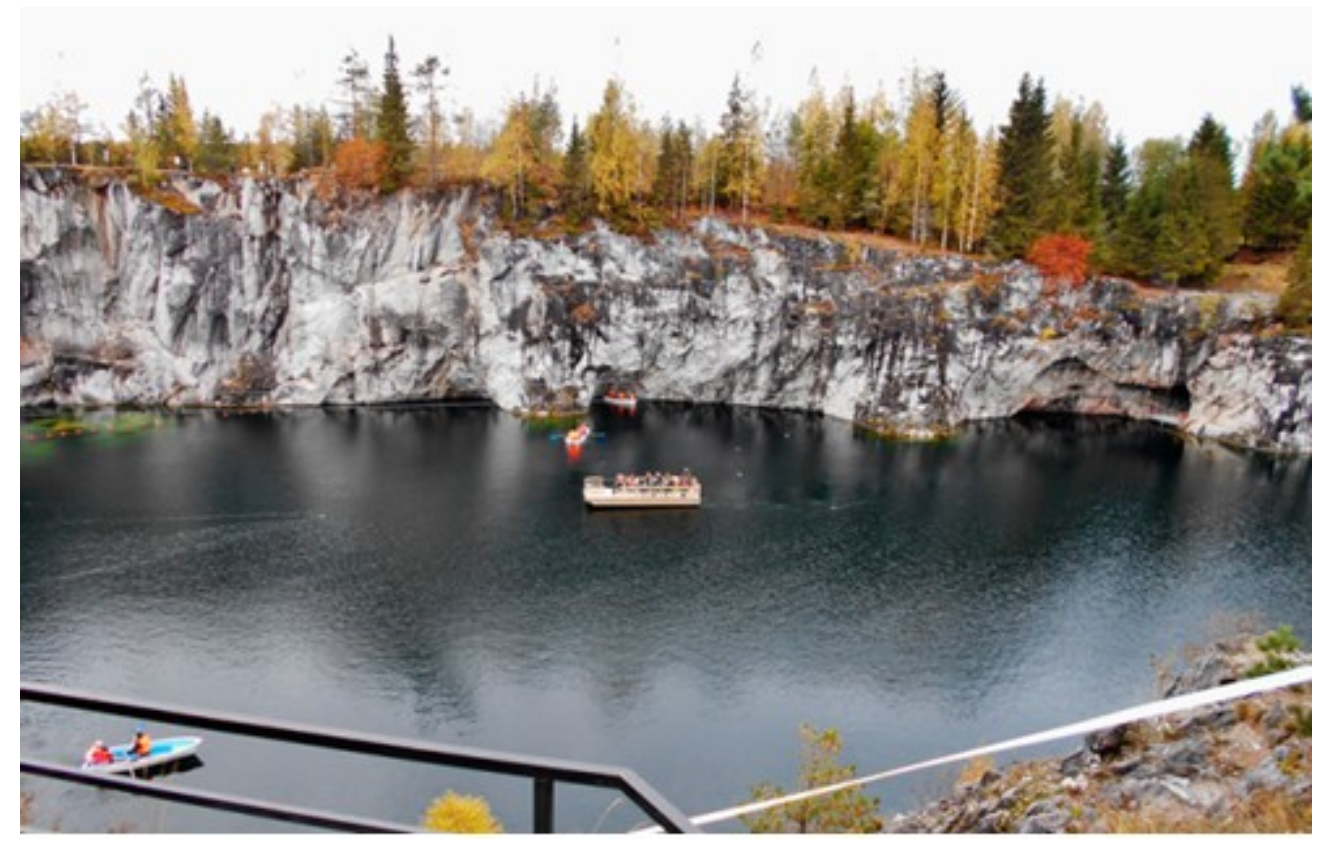

Рис. 17. Горный парк «Рускеала». Водная прогулка на платформе 
Приграничный город Сортавала также является одним из туристических центров Республики Карелия. Немаловажную роль в этом играет его роль как одного из отправных пунктов туристических маршрутов на Валаам и в горный парк «Рускеала», в который ходит ретропоезд «Николаевский экспресс». Большой поток иностранных туристов даёт так называемый ностальгический туризм для бывших жителей Приладожья, проживающих ныне в Финляндии, а также участие города в международном туристическом маршруте «Голубая дорога», протянувшемся от побережья Норвегии через Швецию и Финляндию до карельского Пудожа.

Сортавала является единственным историческим городом Республики Карелия, сохранившим свой целостный архитектурно-исторический облик. Здесь около двухсот памятников архитектуры в стилях финского деревянного романтизма, северного межвоенного модерна, функционализма, неоклассицизма, деревянного ампира середины XIX - начала XX вв. В городе хорошо развита сфера услуг и гостеприимства, действует огромное для малого города число мини-отелей, гостиниц, гостевых домов. Возможное повышение статуса города Сортавала до уровня исторического города федерального значения даст возможность получить дополнительное финансирование из федерального бюджета на создание привлекательной градостроительной среды, в частности на благоустройство и создание новых комфортных общественных пространств. Это также позволит увеличить туристическую привлекательность приграничного города, через который гости Карелии отправляются на Валаам.

В 2016 г. город получил статус новогодней столицы России, приняв большое количество туристов в зимний период. С введением скоростного поезда «Ласточка» в 2018 г, курсирующего между Санкт-Петербургом и Сортавалой, в обозримой перспективе ожидается увеличение турпотока в приграничный город в три раза [69]. В 2019 г. «РЖД» был запущен новый беспересадочный маршрут Москва - Сортавала — парк «Рускеала».

В 2019 г. на территории республики дан старт реализации ТРК «Легенды Карелии». Также формируется ТРК «Карельское Беломорье», запланированный к созданию в 2021 г. [67]. 


\section{5. РЕГИОНЫ РУССКОГО СЕВЕРА}

\section{1. Архангельская область}

Архангельская область является своеобразным хранилищем древнерусской культуры и традиций духовной жизни поморов. На территории региона расположены уникальные историко-культурные ландшафты, всемирно известные памятники деревянного и каменного зодчества, на побережье Белого моря - древние поморские деревни. Архангельская область занимает 5-е место в России по концентрации памятников культурного наследия (рис. 18).

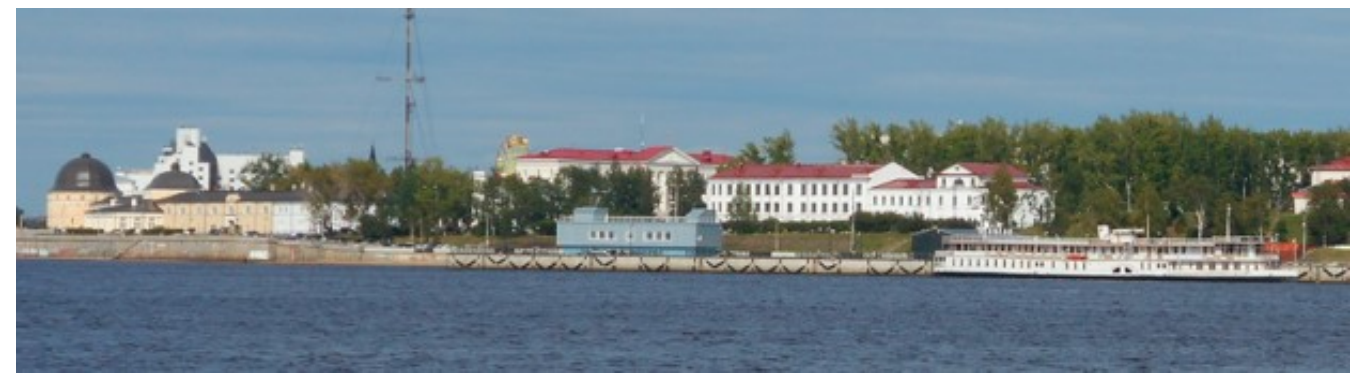

Рис. 18. Архангельск. Набережная Северной Двины

Архангельская область примечательна своей деревянной архитектурой и поморской кухней. Здесь расположен самый крупный в России музей деревянного зодчества под открытым небом «Малые Корелы» (рис. 19). В регионе делают акцент на развитии арктического, сельского и этнографического туризма. В настоящее время действуют более ста этнографических объектов, на базе которых туристам предлагаются экскурсионные программы и мастер-классы, направленные на сохранение традиционных народных традиций и ремесел (рис. 20). Все более популярным в Поморье становится гастрономический туризм. Создана Гастрономическая карта-тетрадь Архангельской области, где представлена информация районов области о местных кулинарных блюдах и фермерских продуктах.

В 2018 г. Архангельскую область посетило 409 тыс. организованных туристов (из них 9 тыс. иностранных), что на 4,6 \% больше, чем в 2017 г. По итогам туристского сезона 2019 г. турпоток увеличился до 427 тыс. человек. В экскурсионных программах области принимает участие более 1 млн человек $[70,71]$. Чаще всего в регион приезжают жители Москвы и Санкт-Петербурга. Среди иностранных гостей Поморья лидируют представители Германии, Финляндии, Швеции, Франции, Италии, Норвегии и Нидерландов. В регионе открываются новые объекты туристской инфраструктуры, разрабатываются новые проекты, экскурсионные программы и маршруты.

В Архангельской области зарегистрирован 21 туроператор по внутреннему и въездному туризму, разработано более ста турпрограмм, действуют двенадцать ТИЦ. Гостей региона принимают 169 гостиниц, хостелов и санаториев. В 2019 г. наибольшая предпринимательская активность в сфере туризма отмечена в Архангельске, Котласе, а также в Котласском, Пинежском, Няндомском и Красноборском районах (рис. 21, 22). 


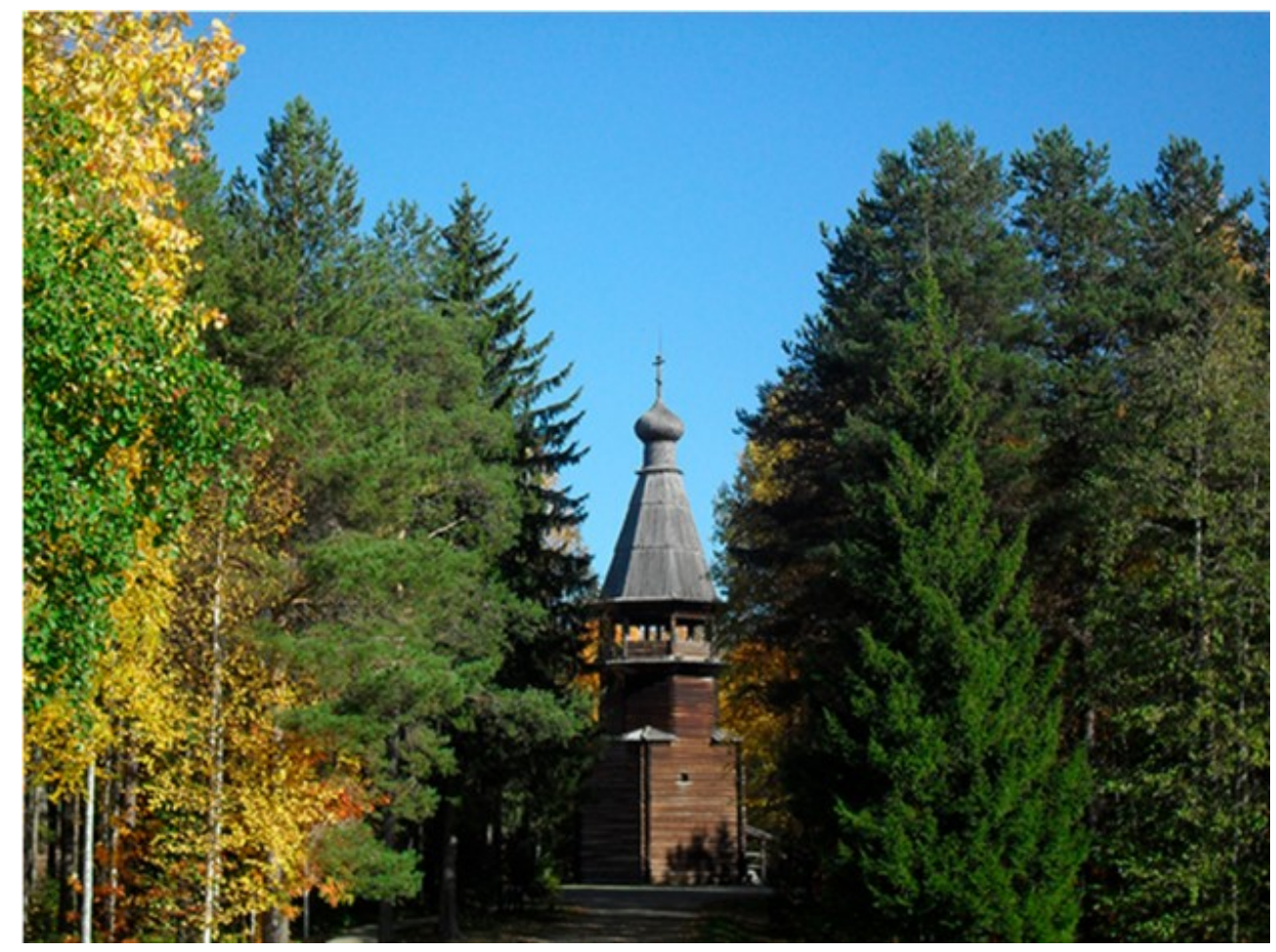

Рис. 19. Музей «Малые Корелы». Шатровая колокольня, вписанная в природный ландшафт

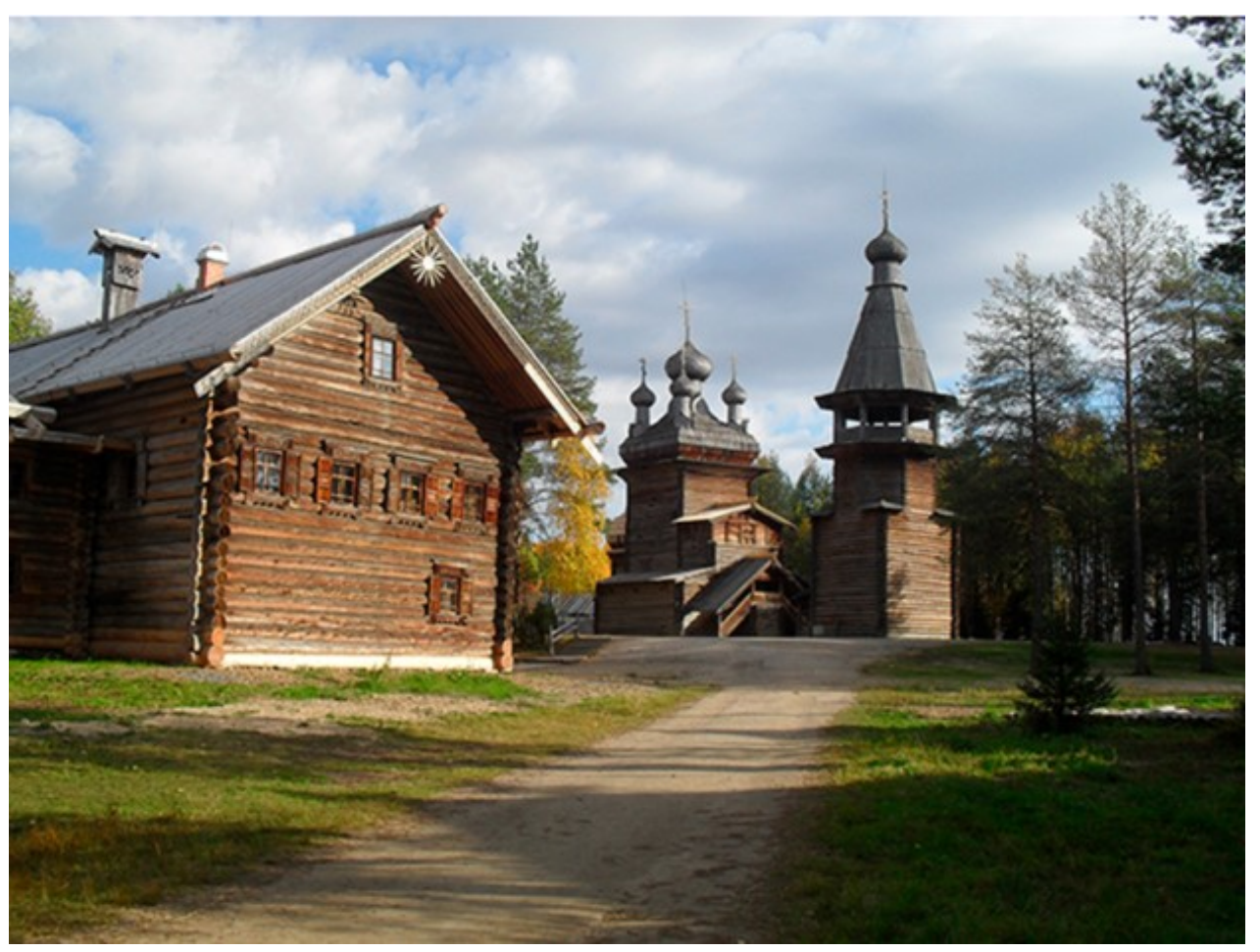

Рис. 20. Музей-заповедник «Малые Корелы». Архитектурно-ландшафтная экспозиция 


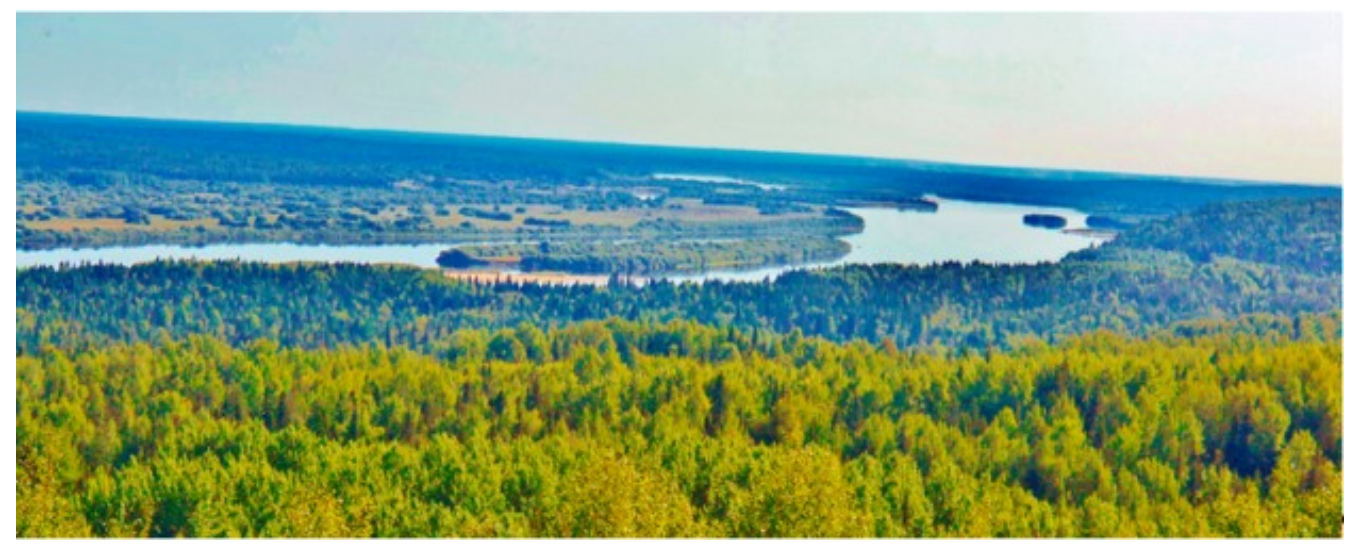

Рис. 21. Вид на Пинегу с Красной Горки (деревня Красная Горка Пинежского района)

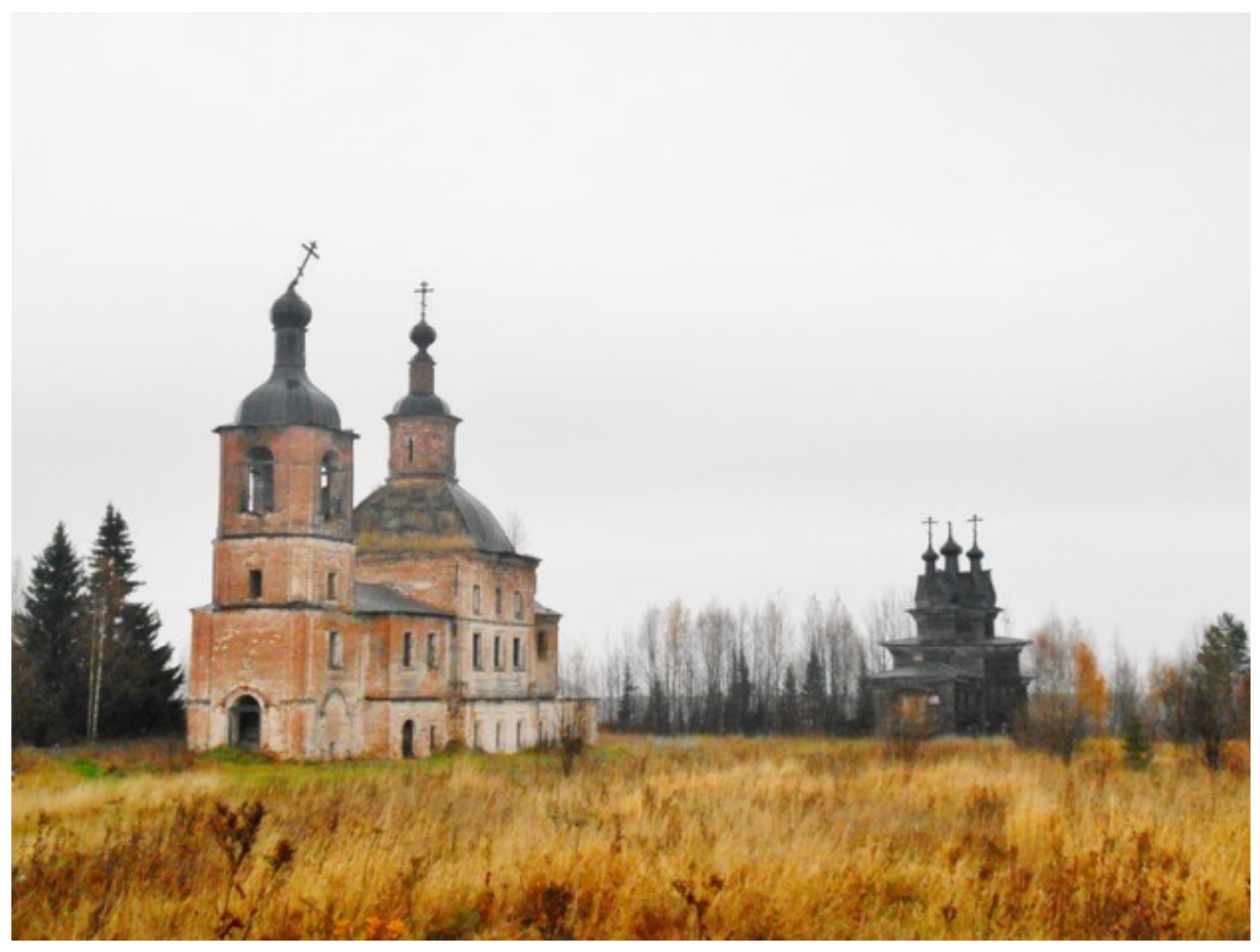

Рис. 22. Святыни Пермогорья (деревня Пермогорье, Красноборский район)

Активными центрами развития сельского туризма стали Пинежский и Мезенский районы. Основная проблема здесь - транспортная доступность: например, на трассе Архангельск - Голубино - Пинега - Мезень дорога постоянно разбивается лесовозами и после дождей становится труднопроходимой. Дорогу до Мезени необходимо строить одновременно с развитием придорожного сервиса и инфраструктуры.

Следует особо отметить проекты, которые в целях повышения туристской и инвестиционной привлекательности региона призваны 
способствовать социально-экономическому развитию территорий, среди них: «Автопутешествие со вкусом» (развитие инфраструктуры для популярных турнаправлений), «АРХИпродукт» (продвижение северной продукции в ключе гастрономического туризма) и «АРХИцентр» (новое социально-культурное общественное пространство в Архангельске в здании Морского-речного вокзала). «АРХИцентр» позволит гостям и жителям региона комплексно познакомиться с историческим и культурным наследием Поморья с помощью современных музейных и мультимедийных средств [71].

В настоящее время в Поморье начата реализация инвестиционного проекта туристского кластера «Беломорский» (Архангельск, село Ломоносово). Ранее предполагалась подача совместной заявки Архангельской и Мурманской областей (ТРК «Беломорский» и «Беломорье») для вхождения в федеральную целевую программу развития туризма на 2019-2025 гг. в РФ [72]. Туризм в Архангельской области - это в первую очередь устойчивый способ развития территории, который улучшает качество жизни местного населения через привлечение гостей.

Путешествия по региону начинаются с Архангельска - первого морского порта России, отправной точки освоения Арктики. Арктическая тема стала лейтмотивом развития туризма в столице Поморья: туристский маршрут «Архангельск: здесь начинается Арктика» отнесен к числу брендовых туров России и включает посещение основных морских и арктических достопримечательностей. В 2018 г. Архангельск посетили 120 тыс. туристов, на $9 \%$ больше, чем в предыдущем году

Новые арктические туристские маршруты выходного дня разработаны в Приморском районе («Патракеевка - родина капитанов», «Пустошь родина лоцманов»), в селе Вознесенье и Онежском районе («Поморы у Белого моря», «Онега - резиденция Царевны Морошки»).

Растет число желающих посетить старинный город Каргополь: в 2018 г. его белокаменная архитектура и многочисленные музеи привлекли более 9 тыс. туристов, что на 18 \% больше, чем в 2017 г. [73]. Этому в немалой степени способствуют туристские маршруты Каргополья, утвержденные в качестве брендовых туров России «Каргополье - край спрятанного времени» и «Каргопольская гостеба». Яркие событийные мероприятия - ежегодный зимний фестиваль колокольного искусства «Хрустальные звоны» и праздник народных мастеров России, направленный на сохранение и развитие традиционных народных промыслов, - в разные годы становились национальными событиями года в России по версии турпортала «Национальный календарь событий». Гастрономические традиции Каргополья развивает экогастрономический фестиваль «Баранье воскресенье».

Для иностранных туристов Русский Север привлекателен прежде всего своей самобытной деревянной архитектурой. Например, КаргопольскоКенозерский туристский регион известен как территория, где сконцентрировано самое крупное в мире количество сакральных памятников деревянного зодчества. Брендом данной территории являются сохранившиеся древние деревянные церкви и часовни с уникальными «росписными небесами», обетные поклонные кресты и святые рощи.

В Каргапольском районе и Кенозерском секторе Плесецкого района расположены уникальные деревни, один из последних островков исконно 
русского жизненного уклада, культуры, традиций, выдающихся образцов культурного ландшафта Русского Севера. Часть этих туристских деревень находится на территории Кенозерского национального парка, единственного в России, где сохранилось около ста памятников архитектуры, среди них шедевры русского деревянного зодчества XVIII-XIX вв., не имеющие аналогов в мире. Парк первым в России пошел по пути реализации идеи устойчивого жизнеобеспечения местного населения деревень через туристическую деятельность. В настоящее время объем туристского потока в национальном парке составляет около 16 тыс. организованных туристов в год. Отличительной чертой предоставляемых туристских услуг и турпродукта является их глубокая связь с местными традициями, с подлинным колоритом северной русской деревни. Поэтому сегодня парк отказался от создания унифицированных стандартных объектов инфраструктуры гостеприимства, сделав акцент на формирование аутентичной атмосферы домашнего деревенского уюта с интерьерами, в которых используются подлинные предметы крестьянского быта [74, с. 38-43].

Развитие Кенозерского национального парка - это редкий пример, когда ООПТ способствует возрождению деревень через проекты по восстановлению архитектуры: храмов, клубов и исторических зданий.

Сразу в три федеральных сборника по туризму в качестве примера лучших практик включен национальный парк «Кенозерский»: «Лучшие практики экологического туризма в Российской Федерации», «Лучшие практики этнографического туризма в Российской Федерации» и «Лучшие региональные практики развития сельского туризма». Развитая туристская инфраструктура национального парка способствует развитию внутреннего и въездного туризма Архангельской области: девять экологических троп, семь экскурсионных маршрутов, 114 туристических стоянок (в том числе пикниковые точки), два пункта аренды велосипедов, восемь смотровых площадок, шестнадцать музеев (в том числе экспозиции, ландшафтные театры), три визитцентра, шесть информационных центров, два экокласса и три конференц-зала. В парке организуется проживание и питание для туристских групп, оборудованы кухни в гостиницах для самостоятельного питания [75].

Культурные ландшафты Кенозерского национального парка наиболее полно и удачно иллюстрируют особенности исторического и культурного развития территорий Севера России и исключительную роль природной составляющей в этом процессе. Особое внимание уделяется изучению элементов традиционной живой культуры как важнейшей ментальной составляющей культурного ландшафта Кенозерья с последующей оценкой ее роли в развитии регулируемого туризма. Национальные парки стали в России одной из основных организационных форм охраны культурных ландшафтов, при этом они обладают колоссальным историко-культурным и экотуристским потенциалом. В последние годы наблюдается тенденция перехода туристской деятельности в культурное пространство национальных парков, на пространство культурных ландшафтов.

Кенозерский национальный парк представляет собой пример наиболее яркого проявления здесь исконно русских традиций, элементов традиционной живой культуры поморов, деревянной культовой архитектуры в гармоничном сочетании с природной составляющей территории. Оценка природного и культурно-исторического наследия данной территории с позиций культурного 
ландшафтоведения и принципов организации культурного пространства приобретает значимость в качестве своеобразного фактора формирования экологической культуры и экологического сознания через туризм [62, с. 168].

В Архангельской области активно развивается сельский туризм, ставший одним из приоритетных направлений развития туристской отрасли. Регион входит в число лидеров по темпам развития сельского туризма в России, что может стать одним из факторов, способствующих диверсификации сельской экономики, повышению занятости и доходов сельского населения; развитию малого бизнеса и в итоге повышению качества жизни на селе.

Архангельская область отличается большим количеством сохранившихся аутентичных деревень, представляющих интерес для туристов. Для их размещения строится сеть гостевых домов. Для активного развития сельского туризма необходимо разрешить открывать мини-гостиницы в частных домах уведомительным порядком.

Все больше иностранных гостей хотят увидеть поморские деревни северных районов области, известные как самобытные центры живой народной культуры, сохранившие вековой уклад жизни, песенную культуру и обряды, народные промыслы.

\subsection{1. Соловецкие острова}

Самым привлекательным туристским объектом Архангельской области являются всемирно известные Соловецкие острова (Соловки). Культурноисторический комплекс Соловецкого монастыря включен в список всемирного наследия ЮНЕСКО (рис. 23). Высочайший туристский потенциал архипелага обеспечивают многочисленные историко-архитектурные объекты монастырской эпохи, уникальные природно-ландшафтные памятники, объекты лагерного периода СЛОН, редчайшие сакральные памятники эпохи неолита. Всего на территории Соловков находится более тысячи объектов культурного наследия [76]. Великая и трагическая история здесь неразрывно переплетается с историей православия. Рядом с монашескими скитами на малых островах везде захоронения лагерных узников.

Практически все население архипелага проживает в поселке Соловецкий (900 человек), в Спасо-Преображенском ставропигиальном мужском монастыре постоянно проживают около ста человек братии. Основным поселкоообразующим предприятием является Соловецкий государственный историко-архитектурный и природный музей-заповедник, создавший 160 рабочих мест из 450 имеющихся в поселке. В летний туристский сезон в музее работает свыше ста приезжих временных сотрудников [77].

Соловецкий музей-заповедник совместно с паломнической службой монастыря разработал около двадцати экскурсионно-туристических маршрутов. Открыты морские экскурсионные маршруты на архипелаг Кузова, Анзерский и Большой Заяцкий острова. На Белужий мыс, где можно наблюдать за белухами, проложена экологическая тропа. Организован новый маршрут «Тундры и салмы Соловков», который включает показ труднодоступной южной части Соловецкого архипелага, где туристы будут передвигаться на специальном транспорте - аэролодке «Нерпа», способной ходить по воде, болотам, мелководью, морским рифам, снегу и льду [78].

Туристический сезон на Соловках длится четыре месяца, с июня по сентябрь, высокий сезон - июль - август. Максимальный пик туристской 
посещаемости приходится на период с 10 по 23 августа, на время проведения основных соловецких событийных мероприятий (фестиваля авторской песни «На Соловецких островах» и главных православных монастырских праздников - Преображения и Собор Соловецких святых). В летний туристический сезон практически все местные жители задействованы в туристическом бизнесе, они сдают все свободные помещения в доме для туристов и паломников. Развитие туризма на Соловках позволило увеличить заработки местного населения.

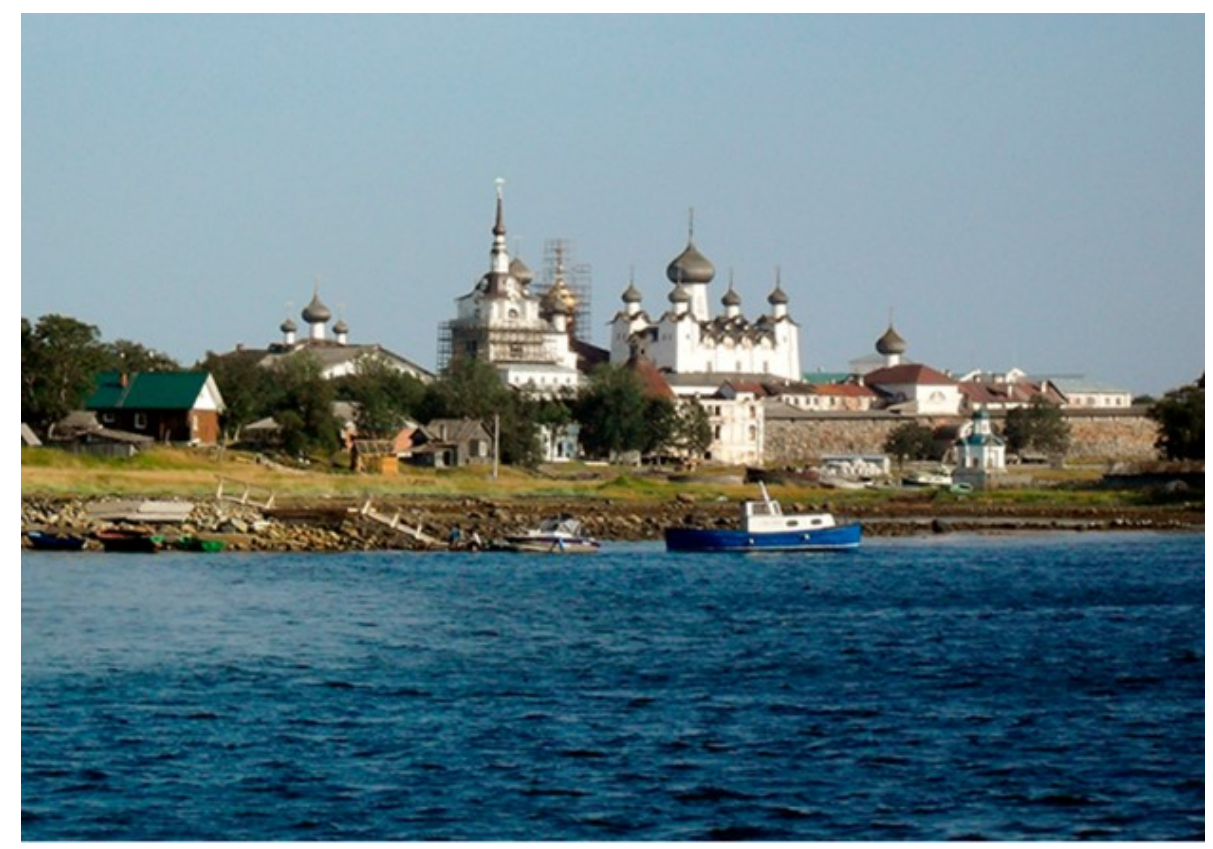

Рис. 23. Панорама Соловецкого монастыря

Сочетание исторических, духовных ценностей и природной уникальности архипелага делает его привлекательным для паломничества и туризма. Чистый ионизированный морской воздух Соловков без автомобильных выбросов и пробок притягивает сюда много туристов из мегаполисов.

В последние годы общее количество посетителей и экскурсантов на архипелаге составляет в среднем 25-30 тыс. человек в год (из них 3-4 тыс. иностранные туристы) [79]. На Соловках девять гостиниц и гостевых домов одновременно могут принять 700 человек, уровень их загруженности в летний период составляет 80 \%. Частный сектор поселка Соловецкий способен принять еще триста человек. Услугами музея-заповедника пользуются в среднем до $2 / 3$ приезжающих на архипелаг гостей. В общей структуре соловецкого туристического потока, по данным местных экспертов-туроператоров, $25 \%$ приходится на организованный паломнический туризм, $60 \%$ - на организованный светский туризм, $15 \%$ - на неорганизованный «дикий» туризм [79, 80].

В настоящий период максимально используются исторически сложившиеся естественные транспортно-географические связи Соловецких островов с Республикой Карелия. Большая часть турпотока (86 \%) направляется 
на архипелаг относительно недорогим морским транспортом со стороны Карелии: через Кемь (самый кратчайший путь, 55 километров) и Беломорск. На этом направлении 80 \% туристов перевозит карельский транспорт [77]. Маршрут на Соловки со стороны Архангельска не пользуется большой популярностью из-за высоких цен на авиаперелет и прекращением прямого морского сообщения.

За 2017 г. Соловки посетили около 18 тыс. туристов. В высокий сезон 2018 г. количество организованных туристов увеличилось до 20 тыс. человек. Турпоток на архипелаг часто зависит от того, какая погода будет на островах. Соловецкие острова ежегодно принимают в среднем от двух до трех круизных лайнеров преимущественно с иностранными туристами [78]. Международный круизный туризм в силу своей специфики (туристы прибывают на Соловки на круизном судне, где и проживают во время посещения архипелага) не должен нанести ущерба хрупким экосистемам и монастырскому укладу жизни Соловецких островов.

Необходимо возродить популярный в прошлом круизный маршрут Архангельск - Соловки, закрытый в настоящее время из-за проблем с речным и морским регистром и из-за отсутствия судов класса «река - море». В перспективе возможно увеличить количество иностранных туристов на Соловках, если восстановить морской круиз из порта Кандалакша, действовавший в советское время. В Кандалакшу туристы смогут прибывать автобусами со стороны российско-финского пункта пропуска Салла.

Можно отметить следующие проблемы в развитии туристической отрасли на Соловках: уровень сервиса и культуры предпринимательства крайне низок; абсолютная разобщенность туроператоров, представляющих Соловки; отсутствие чёткой региональной политики в области развития соловецкого туризма; высокие цены турпродукта; современное обслуживание турбизнеса в большинстве случаев проходит мимо налоговой базы.

Подавляющее число туроператоров и владельцев отелей зарегистрированы в налоговых службах других регионов. Обслуживающих туристов (принимающих) компаний на Соловках три: федеральный музейзаповедник, паломническая служба ставропигиального монастыря и частная компания, обслуживающая не более $5 \%$ туристов. Так как музей и монастырь не платят налогов в районный и областной бюджет, фактически Архангельская область получает налоги только с этих 5 \% и почти ничего не имеет с продаж турпутевок [81].

В экономико-географическом плане Соловки сейчас более привязаны к Карелии, чем к самой Архангельской области. Фактически сегодня существует только административное подчинение и дотации из бюджета Архангельской области на содержание инфраструктуры. При этом весь туризм проходит по территории сельского поселкового муниципалитета, используя его инфраструктуру. Доходы от этого туристического направления получают музей и монастырь.

Большую часть дохода от туризма на Соловках получают Карелия и Москва. Для выхода из сложившейся ситуации Архангельской области необходимо жестко конкурировать на соловецком туристическом рынке, реализуя собственные проекты в области транспортных перевозок (прежде всего в морском транспорте), гостиничного бизнеса и обслуживания туристов. 
Имея административные рычаги управления, область должна создавать инструменты поддержки туризма, одновременно разрабатывая и внедряя партнерские программы с конкурентами и новыми партнерами, например с Мурманской областью.

«Дикого», неорганизованного и развлекательного туризма, наносящего вред Соловкам, не должно быть на архипелаге. Упор должен быть сделан на развитие культурно-познавательного, паломнического, круизного, экологического (например, наблюдение за белухами) и событийного видов туризма. Соловецкий архипелаг включен в федеральный межрегиональный туристический проект «Серебряное ожерелье России».

На основе выполнения рекомендаций ЮНЕСКО разработана система управления архипелагом на основе принципа «пяти соловецких ключей». Этот уникальный опыт по взаимодействию церковной, музейной и светской административной власти в деле развития территории успешно зарекомендовал себя на Соловках и теперь внедряется на родине Иоанна Кронштадтского, в пинежском селе Сура. Все участники синергии «пяти ключей» ставят задачу изменить вектор развития туризма на архипелаге. В первую очередь необходимо видоизменить качественный состав туристского потока в сторону паломнического и религиозно-познавательного видов туризма как наиболее востребованных форм посещения таких духовных святынь, как Соловки. Кроме того, предполагается всячески поддерживать частную музейную деятельность на Соловках, например, планируется расширение уникального комплекса Морского музея за счет использования Сельдяного мыса под экспозиционные и интерактивные площадки (рис. 24) [72].

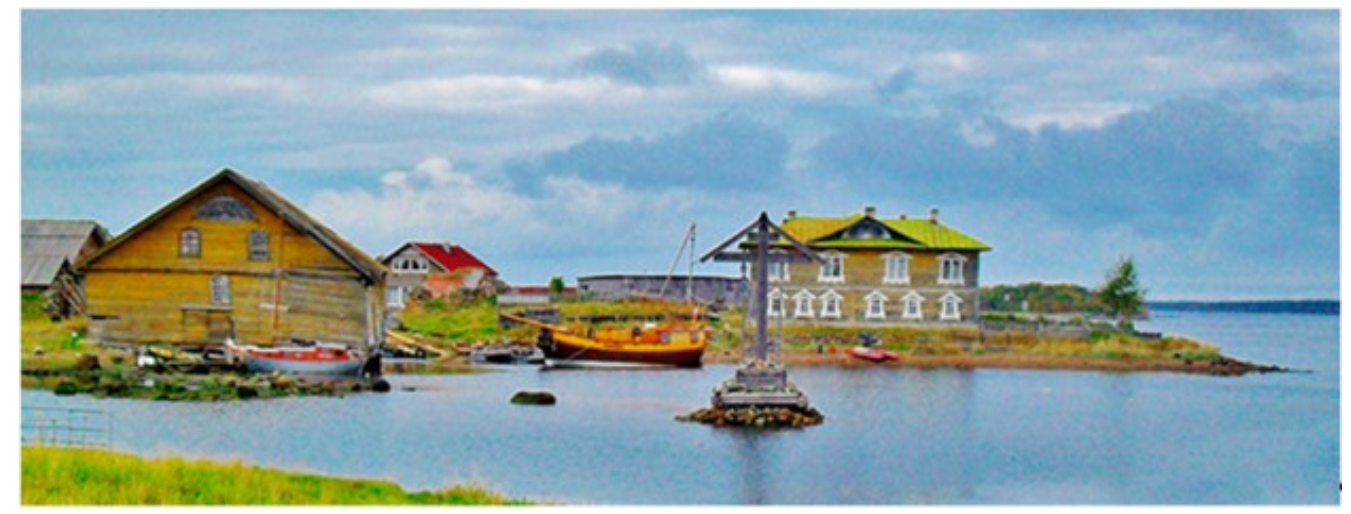

Pис. 24. Соловки — бухта Благополучия у Морского музея

По мнению экспертов, оптимальное количество туристов на Соловках не должно превышать 40 тыс. человек в год и 2 тыс. человек одновременно [80]. Поток «диких», неорганизованных туристов будет регулироваться, чтобы не получить вытоптанный и выжженный остров. Необходимо сохранить духовное наследие Соловков как русского северного Афона - места драгоценной тишины, пустынности и гармонии [82].

В настоящее время принята Стратегия развития Соловецких островов до 2030 г. Кроме того, Спасо-Преображенским монастырем и музеем- 
заповедником разработана Концепция сохранения и восстановления исторического наследия Соловецкого монастыря до 2029 года [79].

Руководство Русской православной церкви и областное правительство предложили наделить территорию Соловков особым правовым статусом достопримечательного места религиозно-исторического значения - с целью сохранения уникального природного, культурного и духовного наследия архипелага с учетом интересов местных жителей. Соловки должны стать пилотной площадкой по отработке механизма функционирования территории в качестве религиозно-исторического места [82]. По замыслу авторов инициативы, для защиты религиозных святынь (например, монашеских скитов) должны быть предусмотрены особые режимы их посещения. Светской территорией на архипелаге должен остаться только административный поселок (рис. 25).

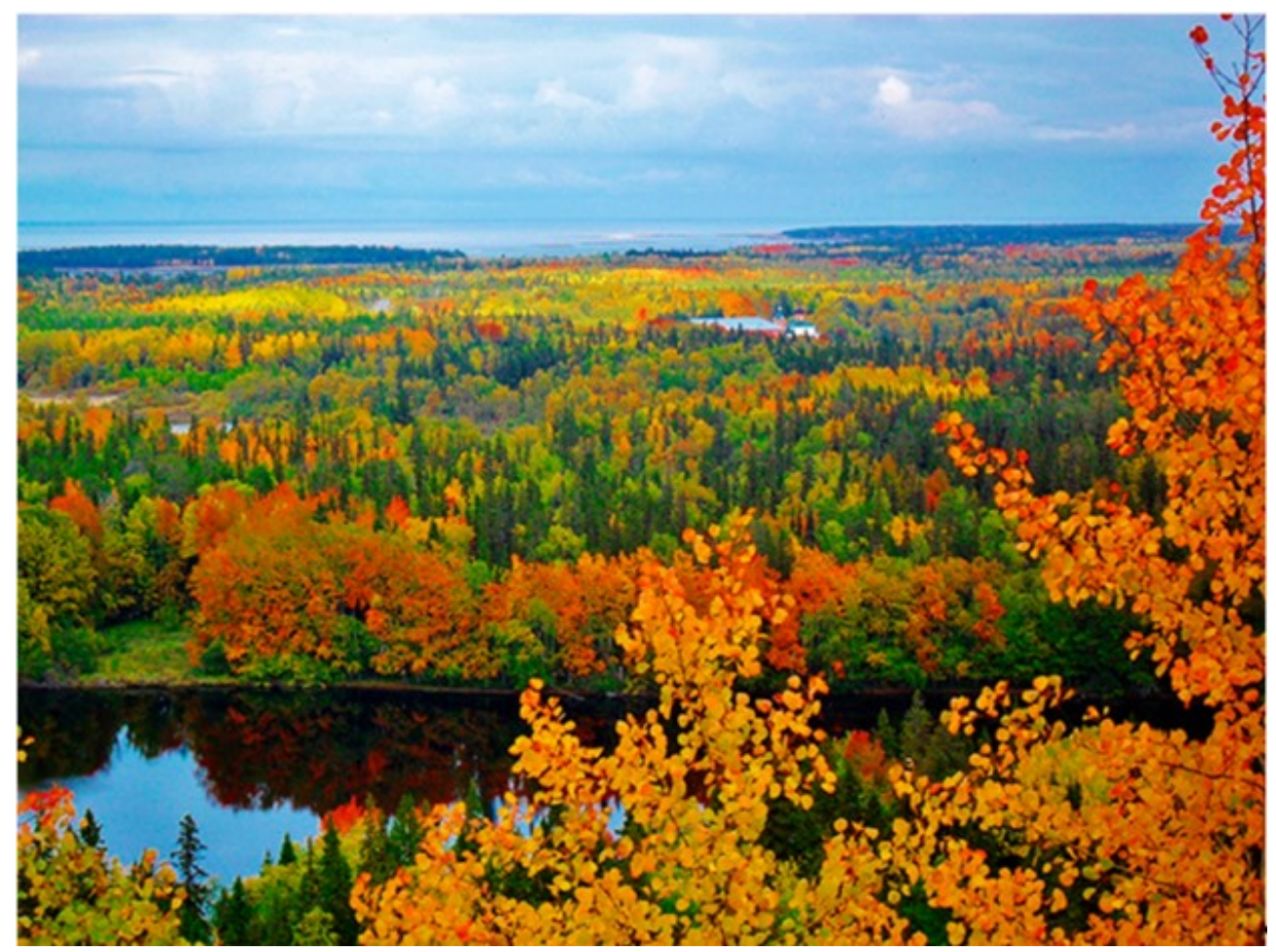

Рис. 25. Соловки. Вид с Секирной горы

В федеральном законодательстве принята поправка, которая вводит в правовой оборот новую разновидность достопримечательного места. Статус «религиозно-историческое место» подразумевает охрану духовного наследия, сохранение и защиту особого уклада жизни монастырей, которые являются объектами культурного наследия и возведены до 1917 г. [83]. Это значит, что на территории (даже туристической) не будет дозволено открывать развлекательные заведения, проводить шумные мероприятия. Доступ к культурным объектам будет согласован с монастырской жизнью наподобие греческого Афона. Помимо Соловков такой статус могут получить также Валаам и Псково-Печорский монастырь. 


\section{2. Вологодская область}

Вологодская область входит в десятку самых популярных у туристов регионов России. Туризм - один из четырех приоритетных отраслей экономики Вологодской области. Привлекательный образ Вологодчины построен на самобытности края как неотъемлемой части Русского Севера с уникальным комплексом объектов: памятников архитектуры, духовных центров, объектов наследия традиционной культуры и памятников природы. По данным рейтингового агентства «Эксперт-РА», Вологодская область занимает 11-е место в Российской Федерации по туристскому потенциалу.

Привлекательность Вологодской области обусловлена богатейшим культурно-историческим наследием. На ее территории расположено более 3500 объектов культурного наследия. По объему музейных фондов и посещаемости музеев Вологодская область занимает второе место в СЗФО (после Санкт-Петербурга) [84].

В регионе активно развивается теплоходный, культурно-познавательный, событийный, экологический туризм, экскурсии. Организации, обслуживающие туристов, предлагают более 250 экскурсий по области, примерно такое же количество внутренних и выездных маршрутов.

На территории региона находятся 82 памятника природы и 77 природных резерватов. В их числе и один из крупнейших национальных парков страны - «Русский Север». По итогам голосования National Geographic Traveler Awards - 2019 Вологодская область одержала победу в номинации «Российский экологический отдых» [85]. Для туристов созданы экологические тропы, позволяющие увидеть природное разнообразие региона, многие турбазы и гостевые дома предлагают отдыхающим поездки по самым красивым уголкам Вологодчины, а также знакомят с местными традициями и культурой. Культурно-исторические памятники Вологодчины находятся в естественном окружении, в единстве с природой и исторической средой.

Вологодская область является российским лидером по брендированию региональных центров туризма. Создание собственных брендов - ключевой фактор привлекательности для туристов. Опыт Вологодской области в продвижении своих территорий начинается с разработки бренда «Великий Устюг - родина Деда Мороза» в 1998 г. С 2014 г. Вологодская область продвигает общий для региона территориальный бренд «Вологодская область душа Русского Севера» и некоторые туристские бренды муниципальных образований, так как создание туристского бренда для конкретной территории часто является способом для её успешного функционирования и устойчивого развития. В настоящее время во всех районах области развиваются 24 туристских бренда [85]: 1) город Вологда — «Культурная столица Русского Севера»; 2) город Череповец - «Череповец - горячее сердце Севера»; 3) Белозерский район - «Белозерск - былинный город»; 4) Вашкинский район - «Белоозеро - Липин Бор - царство Золотой Рыбки»; 5) Великоустюгский район - «Великий Устюг - родина Деда Мороза»; 6) Верховажский район «Верховажье - по дороге Ломоносова»; 7) Вытегорский район - «Вытегория — обитель батюшки Онего»; 8) Грязовецкий район - «Грязовец - южные ворота Вологодчины»; 9) Кирилловский район — «Кириллов - святая земля»; 10) Кичменгско-Городецкий район - «Лесное царство - Кичменгское государство»; 11) Междуреченский район - «Междуречье - клюквенный 
край»; 12) Никольский район - «Никольск - жемчужина Северных Увалов»; 13) Нюксенский район - «Нюксеница - сокровищница народных традиций»; 14) Нюксенский район - «Пожарище - национальная деревня Русского Севера»; 15) Сокольский район - «Кадников - город купеческий»; 16) Тарногский район - «Тарнога - столица меда Вологодского края»; 17) Тотемский район - «Тотьма - город купцов и мореходов»; 18) Тотемский район - «Тотьма - соль земли русской»; 19) Тотемский район - «Тотьма город черной лисы»; 20) Усть-Кубинский район — «Традиции лодочного мастерства»; 21) Устюженский район - «Устюжна - город кузнецов»; 22) Харовский район - «Харовский район - географический центр Вологодской области»; 23) Шекснинский район - «Шексна — территория будущего, самобытность и современность»; 24) Шекснинский район — «Сизьма - самобытный уголок Вологодчины».

В гастрономическую карту Вологодской области входит также около тридцати местных кулинарных брендов.

Вологодская область - прекрасный вариант для всех желающих стать ближе к природе, приобщиться к традиционному деревенскому жизненному укладу. Приоритетным направлением развития сельских территорий Вологодской области является развитие сельского туризма во всех муниципальных районах. В каталоге гостевых домов и баз отдыха Вологодской области представлены 162 средства размещения, расположенных в сельской местности.

Наиболее перспективными центрами деревенского туризма в области можно назвать сёла (Сизьма, Нюксеница, Устье-Кубенское, Пожарище, Тарнога и Рогачиха). Больше всего туристов привлекают яркие событийные сельские мероприятия - фольклорные фестивали и народные праздники, например лодочный фестиваль в Устье или день Тарноги с медовым фестивалем (рис. 26-28). В исторической деревне Пожарище Нюксеницкого района реализуется туристский проект «Национальная деревня Русского Севера» на основе возрождения этнокультурного ландшафта, народных традиций и промыслов. На обзорной экскурсии по русской деревне гости знакомятся с историческим прошлым, старинными крестьянскими постройками XIX в., участвуют в театрализованных этноспектаклях («Традиционная свадьба») и программах, в деревне сохранились традиции проведения народных праздников [72].

Старинное село Сизьма Шекснинского района становится одним из самых известных объектов сельского и паломнического туризма Русского Севера. В селе с населением в 230 жителей открыто пять музеев - музей хлеба, пива, льна, истории Сизьмы и «Крестьянская изба». Сельский турпродукт включает в себя посещение святых мест, в том числе святых источников, участие в народных праздниках, дегустацию блюд традиционной народной кухни (сиземских щей, пирогов и пива). Ежегодно Сизьму посещает более 30 тыс. туристов [86]. 


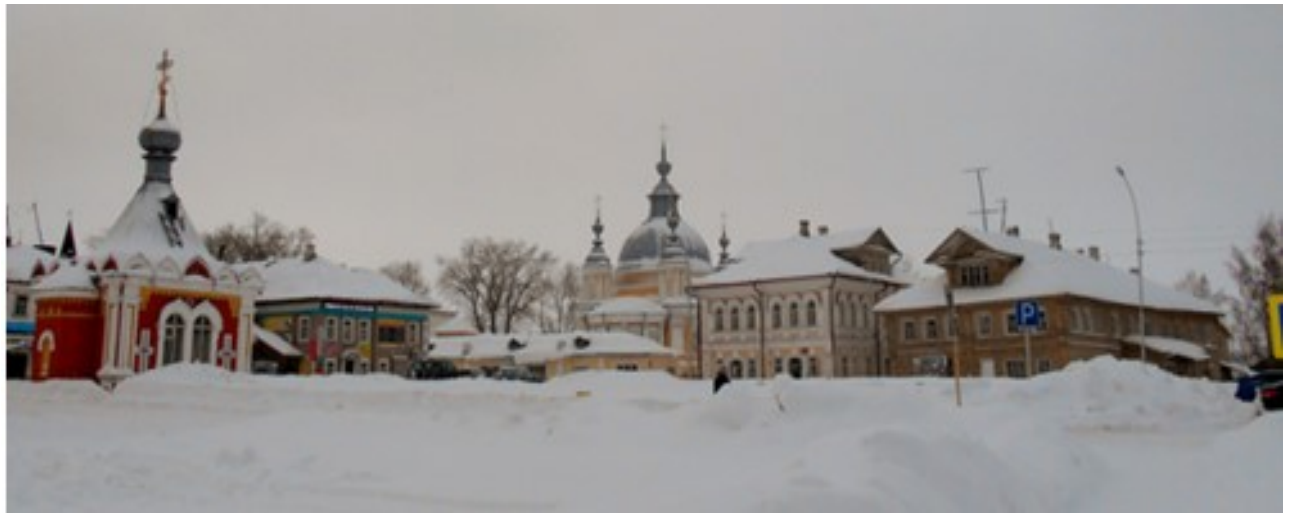

Рис. 26. Село Устье-Кубенское, Вологодская область

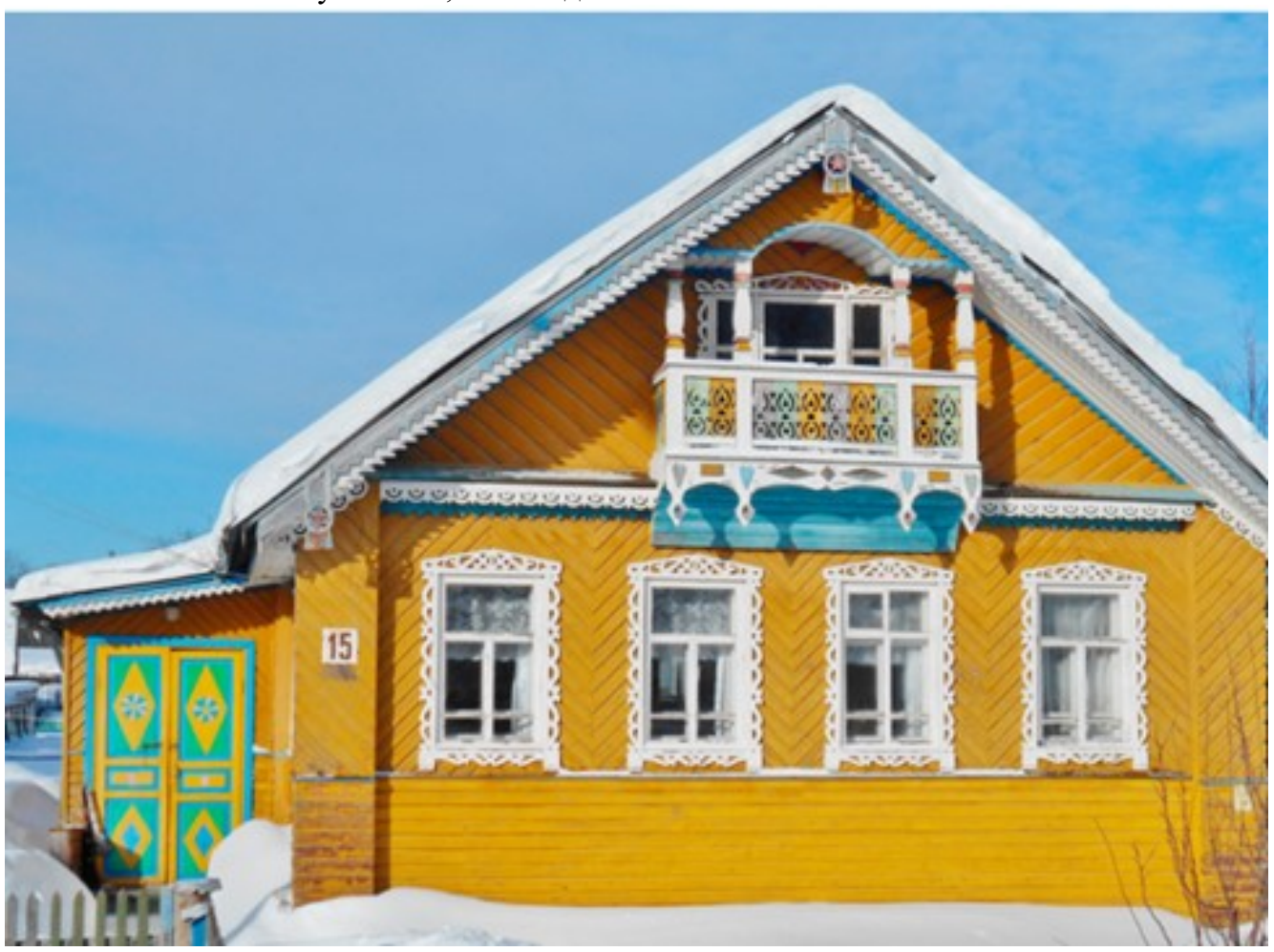

Рис. 27. Село Тарнога, Вологодская область 


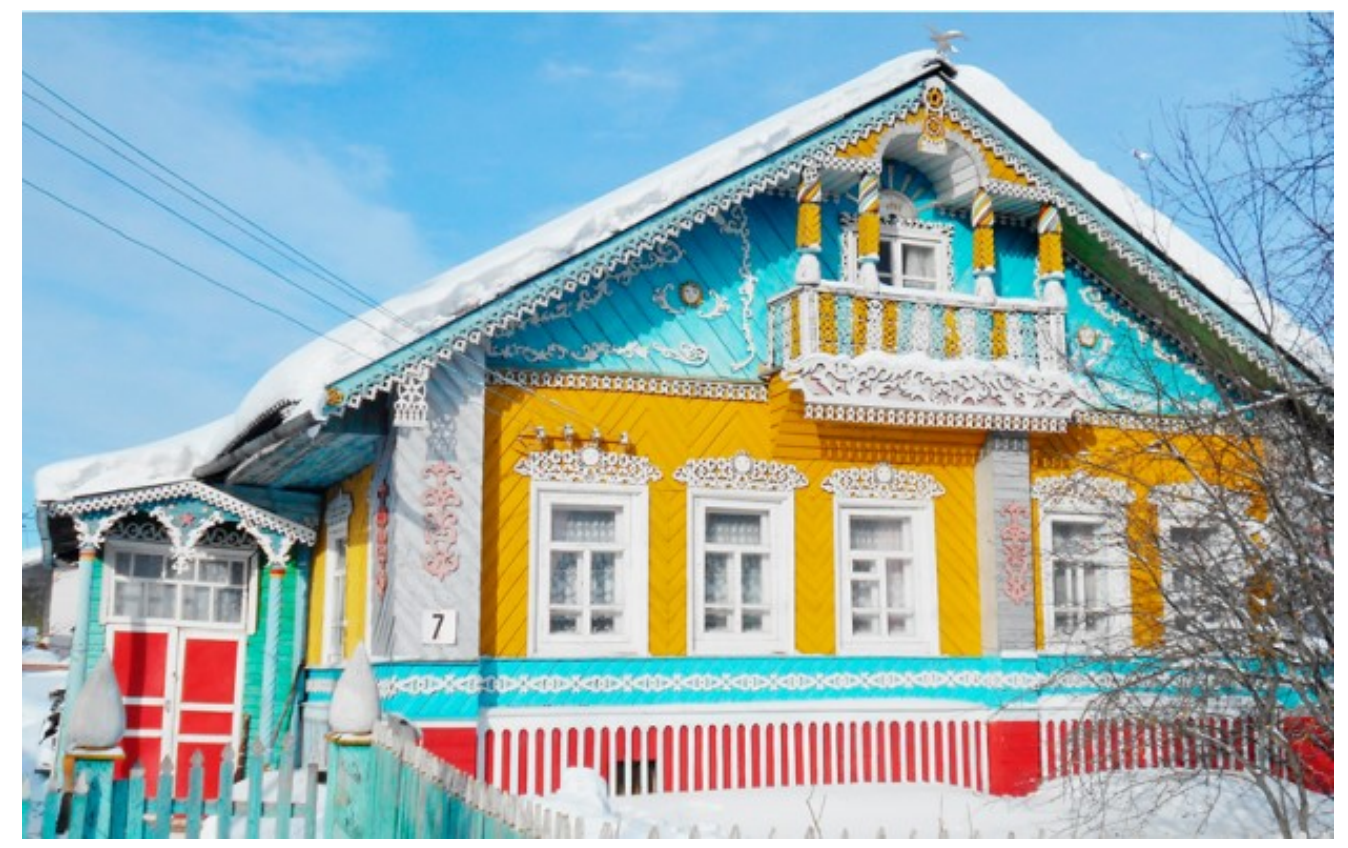

Рис. 28. Село Тарнога. Народное деревянное зодчество

Вологодская область - духовное место, крупнейший центр северной иконописи. Здесь расположено пять действующих монастырей. Самобытность края - в большом разнообразии исконно вологодских народных промыслов (северная чернь, шемогодская резьба по бересте, мороз по жести, вологодское кружево и великоустюгская финифть).

В регионе находятся признанные шедевры русского искусства, пятнадцать населенных пунктов региона имеют высокохудожественные градостроительные ансамбли и комплексы, среди которых Вологда, Белозерск, Кириллов, Ферапонтово, Тотьма и Устюжна. Сюда проложены самые популярные туристские маршруты.

По итогам 2019 г. туристский поток в области составил 3,15 млн посетителей, из них туристов - 739 тыс. человек, экскурсантов - 2,411 млн человек. Туристский поток увеличился по сравнению с 2018 г. (3,086 млн посетителей) на 2 \% [87, 88] (табл. 5).

Таблица 5

Туристский поток в Вологодскую область, тыс. чел.

\begin{tabular}{|l|r|r|r|r|}
\hline \multicolumn{1}{|c|}{ Показатель } & \multicolumn{1}{|c|}{2016 г. } & \multicolumn{1}{|c|}{2017 г. } & \multicolumn{1}{c|}{2018 г. } & \multicolumn{1}{c|}{2019 г. } \\
\hline Количество посетителей области & 2812 & 2901 & 3086 & 3150 \\
\hline Из них & & & & \\
\hline туристы & 769 & 723 & 723 & 739 \\
\hline экскурсанты & 2043 & 2177 & 2354 & 2411 \\
\hline
\end{tabular}


Наиболее активно развивается круизный туризм: 138 тыс. туристов посмотрели на Вологодчину на борту 760 туристических судов в летний навигационный сезон 2019 г. Лидером по круизам остается Кирилловский район. Около 40 \% гостей, которые проплыли по рекам и каналам Вологодской области, - иностранные туристы [89].

В десятку лидеров области по туристскому потоку вошли: города Вологда, Череповец и Кирилловский, Великоустюгский, Вологодский, Тотемский, Шекснинский, Вытегорский, Грязовецкий, Белозерский муниципальные районы. Основная масса туристов Вологодской области посещает экскурсионные объекты Кирилловского района, который занимает лидирующее положение в круизном туризме области и принимает ежегодно более 350 тыс. гостей. Доля туризма в структуре ВРП области с учетом мультипликативного эффекта оценивается в 4,0\%. Общий совокупный доход от въездного туризма в 2018 г. составил 20 млрд рублей, сформировав порядка $3,5 \%$ ВРП [86, 88].

В Топ-10 самых посещаемых объектов туристской индустрии на территории Вологодской области по итогам 2019 г. вошли: Вотчина Деда Мороза, Кирилло-Белозерский музей-заповедник, Вологодский государственный историко-архитектурный и художественный музей-заповедник (Вологодский кремль), Музей фресок Дионисия, архитектурно-этнографический музей Вологодской области «Семёнково», Краеведческий музей Тотьмы. Новый промышленный тур предполагает посещение музея металлургической промышленности и галереи стана 2000 на Череповецком металлургическом комбинате «Северсталь».

За восемь последних лет туристский поток в Вологодскую область увеличился более чем в два раза. Прогнозируется, что доля туризма в ВРП увеличится к 2030 г. до 7 \%, а количество туристов достигнет 5 млн человек [86].

Ещё больше усилит туристический поток запуск новых уникальных туристских маршрутов Вологодской области (например, «Русские усадьбы»), которые вошли в межрегиональный проект «Серебряное ожерелье России». Для развития круизного туризма на Вологодчине планируется создать туристский кластер «Русские берега». Проект, вошедший в федеральную целевую программу «Развитие туризма в РФ на 2019-2025 гг.», подразумевает строительство объектов туристской инфраструктуры в шести региональных субкластерах вдоль движения круизных судов по Волго-Балту [86]. В первую очередь остро нуждается в сооружении причального комплекса самый древний и самый музейный город Русского Севера - Белозерск.

\subsection{1. Белозерск}

Белозерск является самым древним городом Русского Севера. Он входит в тройку городов, от которых «есть пошла Русская Земля», так как, согласно летописям, именно в этот город в 862 г. «сел» родной брат легендарного Рюрика, варяжский князь Синеус. Основной туристский бренд города сформирован как «Белозерск - былинный город Руси изначальной» (рис. 29). Символами Белозерска являются: Белое озеро, судак, кукла «Белозерская сударыня», Земляной кремль, Успенский и Спасо-Преображенский соборы. 


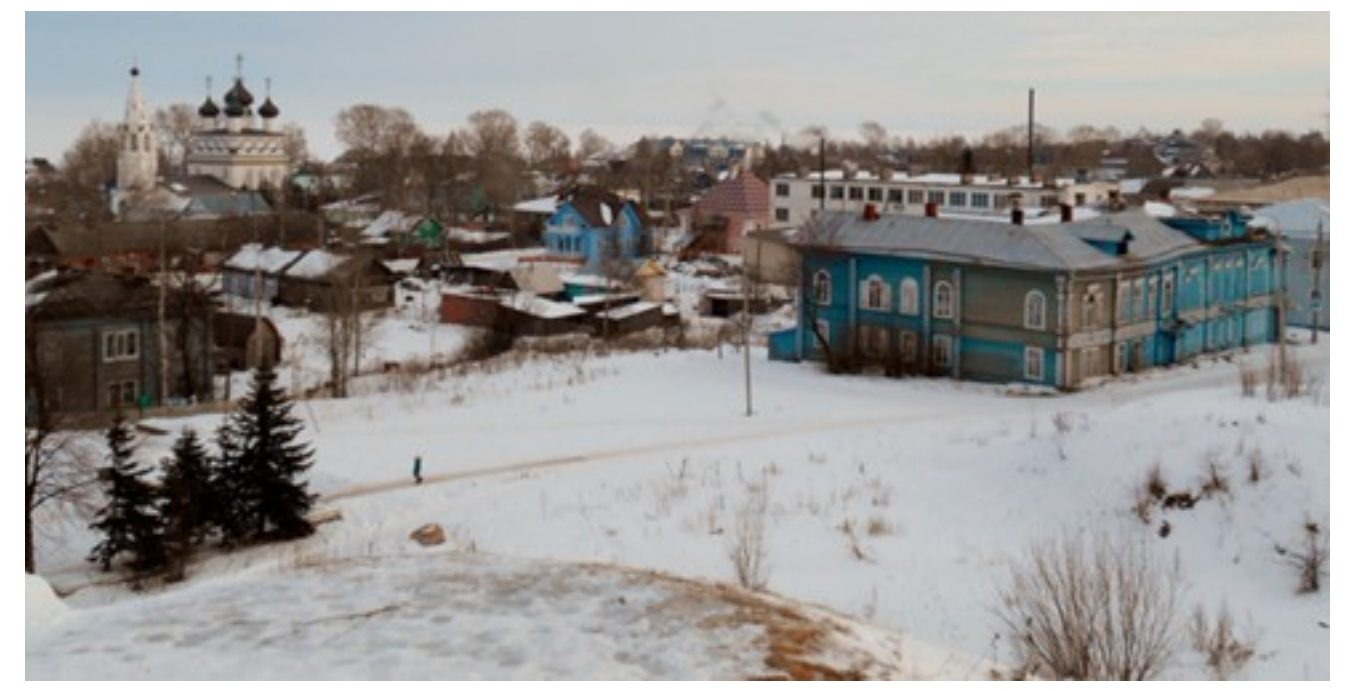

Рис. 29. Белозерск

Не только история города связана с озером. Белое озеро стало и основой экономической жизни города, и осевой линией архитектурного силуэта Белозерска, который во многом обусловлен ландшафтными особенностями города, определяющим фактором среди которых было и остается Белое озеро седьмое по величине в Европе.

Неотъемлемой особенностью панорамы Белозерска является глубокое и органичное единство с окружающим природным ландшафтом. Это единство выражается в максимальном учете всех особенностей местной топографии, что еще больше усиливает общее впечатление живописности и придает городу индивидуальный, неповторимый характер [90].

Комплекс Белозерского кремля с величественными земляными валами одна из главных достопримечательностей, которая до сих пор поражает воображение своей грандиозностью, оставаясь главной архитектурной доминантой города. Насыпанные в конце XV в. валы достигают 30 метров в высоту - это крупнейшее в России кольцо городских валов.

Уникальный архитектурный облик города представлен сочетанием деревянной, каменной исторической застройки и церковными зданиями. При общей малой этажности застройки Белозерска особую роль в его силуэтности сыграли храмы, существенно выделяющиеся на общем фоне и являющиеся главными высотными акцентами. Практически все белозерские церкви имеют очень четкую привязку к ландшафту города - они маркируют основные ступени в рельефе, располагаясь почти на самых бровках озерных террас, благодаря чему подчеркивалась многоплановость белозерской панорамы [90]. Архитектурными доминантами в культурном ландшафте Белозерска являются четырнадцать сохранившихся в разной степени культовых сооружений XVI-XIX вв., из них четыре действующих православных храма. Единственная в городе деревянная Ильинская церковь XVII в. (музейный объект показа) в настоящее время в разобранном состоянии находится в стадии реставрации.

Белозерск является одним из самых целостных по архитектурному наследию уездных городов России (среди малых городов не более 10 тыс. 
жителей) наряду с Каргополем, Чердынью, Солигаличем и Суздалем. На территории города находится 80 объектов культурного наследия памятников архитектуры и исторических зданий. Главной особенностью застройки Белозерска является сочетание одно- и двухэтажных деревянных домов и каменных особняков XIX в. (также преимущественно двухэтажных). Архитектурное наследие Белозерска представлено классицизмом, русским стилем, эклектикой и модерном. В Белозерске хорошо сохранилась каменная застройка в стиле классицизма первой половины и середины XIX в.

Основу средовой исторической застройки составляют старинные деревянные дома с мезонинами, кружевными наличниками, ажурными светелками и дымниками. Деревянные особняки Белозерска украшают резные фризы и подзоры. Отрадно, что традиции русского народного деревянного зодчества и домовой резьбы местные жители продолжают и сохраняют в настоящее время.

Несмотря на огорчительные потери ряда памятников, город и сейчас сохранил заложенное в нем глубокое понимание красоты городского ландшафта и такие характерные особенности, как живописность, органичная связь с окружающей природой и богатство силуэта [90].

Белозерск является самым «музейным» городом Русского Севера - на 9 тыс. населения приходится одиннадцать музеев. Традиционное знакомство с достопримечательностями отходит на второй план, больше внимания сотрудниками музеев уделяется интерактивным программам, экскурсиям

с элементами театрализации и квеста, когда туристы принимают активное участие в играх, мастер-классах и праздниках.

Белозерскому областному краеведческому музею принадлежит пять музейных экспозиционных зданий, включая Спасо-Преображенский собор и уникальный Музей Белого озера - второй лимнологический музей в России. В 2016 г. в Музее Белого озера реализован интерактивный проект «Голубая жемчужина Русского Севера». Белое озеро входит в пятерку самых популярных у туристов озер России. Благодаря усилиям сотрудников краеведческого музея в Белозерске появились первые знаки и информационные стенды туристской навигации возле основных музейных объектов показа. У Белозерского кремля и на прилегающей к нему территории находятся четыре интерактивных музея «Княжеская гридница», «Кузница», «Длинный дом викингов» и частный музей традиционных лодок Белозерья. В настоящее время внутри кремля реализуется проект по созданию историко-архитектурного комплекса «Княжий двор», посвященного средневековой истории Древней Руси. Это новое направление в туристской деятельности Вологодской области, предполагающее воссоздание жилых и производственных построек Древней Руси XI-XIII вв., возрождение элементов традиционной народной культуры того времени и реконструкцию костюмов, воинского снаряжения, предметов быта.

Стал уже популярным новый туристский объект в Белозерске - «Княжеская гридница», использование нетрадиционных форм обслуживания туристов на основе воссоздания по научным и археологическим данным целого комплекса объектов и предметов быта, характерных для средневековой Руси. Экскурсии здесь проходят в интерактивном режиме [85]. Также в городе 
открыты культурно-музейный центр имени поэта С. Викулова и Центр ремесел и туризма с выставочным залом и туринфоцентром.

Туризм для Белозерска - одно из основных стратегических направлений развития. У города есть все ресурсы стать туристическим центром (великолепное Белое озеро, красивейшие северные ландшафты, богатая история, памятники архитектуры, живописи, интересные литературные традиции), несмотря на удалённость от популярных маршрутов.

Ежегодно Белозерск посещают около 80 тыс. туристов и экскурсантов, из них около $36 \%$ остаются ночевать в городе. В последнее время активно вкладываться в развитие города стал частный бизнес, улучшаются условия для туристов, модернизируется существующая инфраструктура, открываются новые музеи, кафе, гостевые дома. В результате чего туристский поток постепенно растет [86]. Разработана муниципальная программа развития туризма «Белозерск - былинный город».

Основными перспективными видами туризма являются: культурнопознавательный, водные круизы, событийный, паломнический, пляжный, гастрономический. Также целесообразно развивать в Белозерске экскурсионный туризм по творческому наследию Василия Шукшина по аналогии с алтайским селом Сростки, поскольку в Белозерске и его окрестностях снимался его фильм «Калина красная».

Турбизнес и связанный с ним приток дополнительных средств может стать градообразующей основой экономики Белозерска. Превращение города в летнюю столицу туризма Вологодской области (наряду с Кирилловым) возможно лишь после решения главной транспортной проблемы - сооружение причального комплекса для круизных теплоходов, идущих по Волго-Балту [91]. Перспективным направлением в развитии района является туристская дестинация «Белоозеро», в которую входят три соседних района: Белозерский, Вашкинский и Кирилловский.

В Белозерске действует пять объектов размещения (гостиница, база отдыха, три гостевых комплекса и дома) на 140 мест [85]. В дни проведения крупных событийных мероприятий возникает проблема с размещением большого количества туристов. Основными событийными мероприятиями являются: день города, межрегиональный фестиваль «Былины Белоозера» и праздник рыбака. Практически все гости города отмечают особую атмосферу душевного комфорта Белозерска, которая складывается из нескольких компонентов: тишина, спокойствие, уют и малоэтажность.

Белозерск вошел в перспективные межрегиональные ганзейские туристические маршруты и проекты, в том числе в ганзейский туристскопознавательный проект «Путями Прокопия Праведного», который является частью межрегионального проекта «Ганзейские дороги России». Сетевой проект Русской Ганзы направлен на интеграцию туристского потенциала русских городов, развитие культурно-исторического и событийного туризма на основе возрождения культурного наследия и привлечения иностранных инвестиций, прежде всего из Германии и Швеции. В рамках празднования в 2012 г. 1150 -летнего юбилея Белозерск стал местом проведения русского Ганзейского фестиваля, на который приехало 20 тыс. туристов. По случаю юбилея города в развитие и реставрацию его культурно-исторического наследия был вложен 1 млрд рублей [92]. Благоустроена новая набережная Белозерского обводного 
канала, в 2015 г. на ней установлен памятник белозерскому судаку. На берегу озера оборудован песчаный пляж.

Участие в мегапроекте «Серебряное ожерелье России» — большой плюс для Белозерска, который становится членом авторитетного туристского сообщества, объединяющего одиннадцать регионов Северо-Запада России. На сегодняшний день Белозерск представлен в «Серебряном ожерелье» маршрутом «Маэкса - рыбацкое село» [92]. Маэкса — старинное село в трех километрах от города. Если говорить о перспективах участия в «Серебряном ожерелье», то Белозерск вполне мог бы стать частью межрегионального ганзейского маршрута «По следам викингов на территории Восточной Европы», включающего посещение старейших русских торговых городов.

Из факторов, сдерживающих развитие туризма, главный - недостаточная транспортная доступность территории и некоторая удаленность от основных транспортных и туристских коридоров. Отсутствие причала сделало невозможным прием туристических теплоходов. Крупные круизные суда, идущие по Волго-Балту и Мариинской водной системе, не заходят в Белозерск из-за технических проблем. Причалить к белозерскому причалу могут только маломерные суда. В настоящее время пассажиры круизных теплоходов, высадившись на берег в Череповце (в 115 километрах), доставляются в Белозерск автобусами.

Начиная с 2016 г. разрабатывался проект строительства причального комплекса, рассчитанного на прием 500 туристических судов в год (100 тыс. круизных туристов). В результате строительства причального комплекса ожидается увеличение общего туристического потока в Белозерск в 2-2,5 раза [85].

Рассматривалось два возможных варианта строительства причала. Первый вариант - сделать его непосредственно в Белозерске, что потребует немалых средств на дноуглубительные работы, которые необходимо проводить каждый год. Второй вариант (более экономичный) - размещение причала в Крохино, в 17 километрах от Белозерска, туристов в город доставляли бы автобусами [93]. Район Крохино является своеобразным археологическим заповедником с большим культурным слоем: до XIV в. здесь, в истоке Шексны, находился град Белоозеро, перенесенный сюда с северного берега озера. Белоозеро после создания Волго-Балта сильно пострадало от затопления. В Крохино возможна организация археологического музея затопленного города.

Для привлечения туристов в Белозерск целесообразно дальнейшее улучшение городской среды на базе создания новых объектов показа. Например, организация пешеходной музейной улицы, установление объектов малой городской скульптуры (памятники Шукшину, Белозерской Сударыне, князю Синеусу) и инсталляций, связанных с богатой историей и символами города. Так, в Белозерске реализован инновационный проект «Белозерск - город тысячи камней», направленный на создание новых природно-художественных арт-объектов экскурсионного показа с использованием крупных камней.

\subsection{2. Великий Устюг}

Самым успешным реализуемым туристским проектом и брендом Европейского Севера стал инвестиционный проект «Великий Устюг - родина Деда Мороза». Малый северный город стал одним из наиболее активно 
развивающихся туристских центров региона, попав в Топ-10 самых посещаемых городов страны. Великий Устюг занимает первое место среди городов России с лучшими условиями для новогоднего отдыха.

Туризм приносит до $30 \%$ дохода местного бюджета, 11 \% жителей города занято в туристском бизнесе. В течение двадцати лет (1998-2018 гг.) туристский поток вырос в сто раз (с 3 до 300 тыс. человек), число гостиниц за время реализации проекта выросло в сорок раз, количество предприятий общепита увеличилось в двеннадцать раз, совокупные частные инвестиции в туристическую инфраструктуру города достигли 4 млрд рублей [94].

Вотчина Деда Мороза расположена в сосновом бору, на берегу реки Сухоны, в 12 километрах от города Великого Устюга. Она занимает 43 гектара, где размещены гостиничный комплекс из деревянных коттеджей, сауна и русская баня, зимний сад и ледник, ресторан, фольклорный центр и зоопарк.

Великий Устюг также известен своими народными художественными промыслами, уникальным вологодским говором - северным диалектом русского языка, памятниками церковной и гражданской архитектуры мирового уровня. Все это предопределяет возможное включение Великого Устюга в список всемирного культурного наследия ЮНЕСКО (рис. 30).

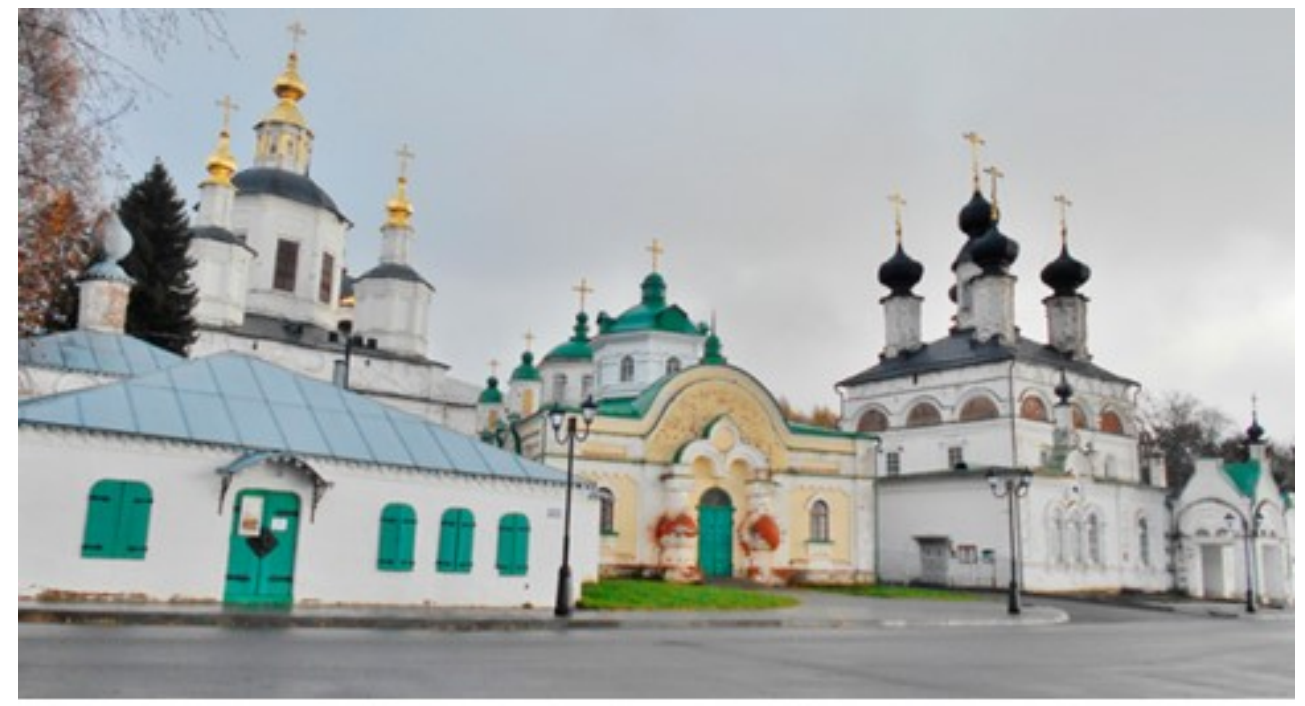

Рис. 30. Великий Устюг. Храмовый комплекс

Для развития туризма в первую очередь необходимо улучшать транспортное сообщение с Великим Устюгом. Ввиду слабого использования в последние годы железнодорожной станции Великий Устюг (построенный в 1982 г. вокзал в основном простаивал) и аэропорта, туристы вынуждены были доезжать до Котласа, а дальше на автобусе или такси доезжать до туристической зоны. Кроме того, железнодорожное сообщение в данном направлении не справляется с возросшим потоком туристов. Необходимо организовывать прибытие большинства туристских поездов в Великий Устюг (первые поезда в город прибыли в новогодние праздники 2021 г.), развивать гостиничный фонд и повышать качество обслуживания. На данный момент имеет место серьезный 
дефицит хороших средств размещения в городе. При планируемом увеличении турпотока в город необходимо предусмотреть строительство больших комфортабельных отелей и при этом не делать акцент только на зимний сезон, который традиционно отличается повышенным спросом [95].

Поток туристов в Великий Устюг в краткосрочной перспективе может вырасти в два раза, с нынешних 300 до 600 тыс. человек в год благодаря созданию укрупненного туристского кластера на основе расширения действующей Вотчины Деда Мороза и федеральному проекту «Сказочная Россия». В рамках инвестиционного проекта в конце 2020 г. в городе завершена реконструкция аэропорта с удлинением взлетно-посадочной полосы (стоимость проекта - 1,3 млрд рублей), что позволит после снятия ограничений в постпандемийный период принимать воздушные суда международного класса с иностранными туристами, а также организовать в Великий Устюг прямые перелеты из Москвы, Санкт-Петербурга и других крупных городов. В 2021 г. на территории вотчины планируется построить новый дворец Деда Мороза, так как пропускная способность существующего терема Деда Мороза ограничена - не более 6-6,5 тыс. человек в сутки. Также будет построена вторая очередь интерактивного зоопарка Деда Мороза.

Предполагается увеличить объем средств на реконструкцию сохранившихся до наших времен монастырей и храмов города, укрепление берегов реки Сухоны и продление прогулочной набережной с 520 метров до трех километров, что сделает ее самой протяженной на Русском Севере (рис. 31) [96].

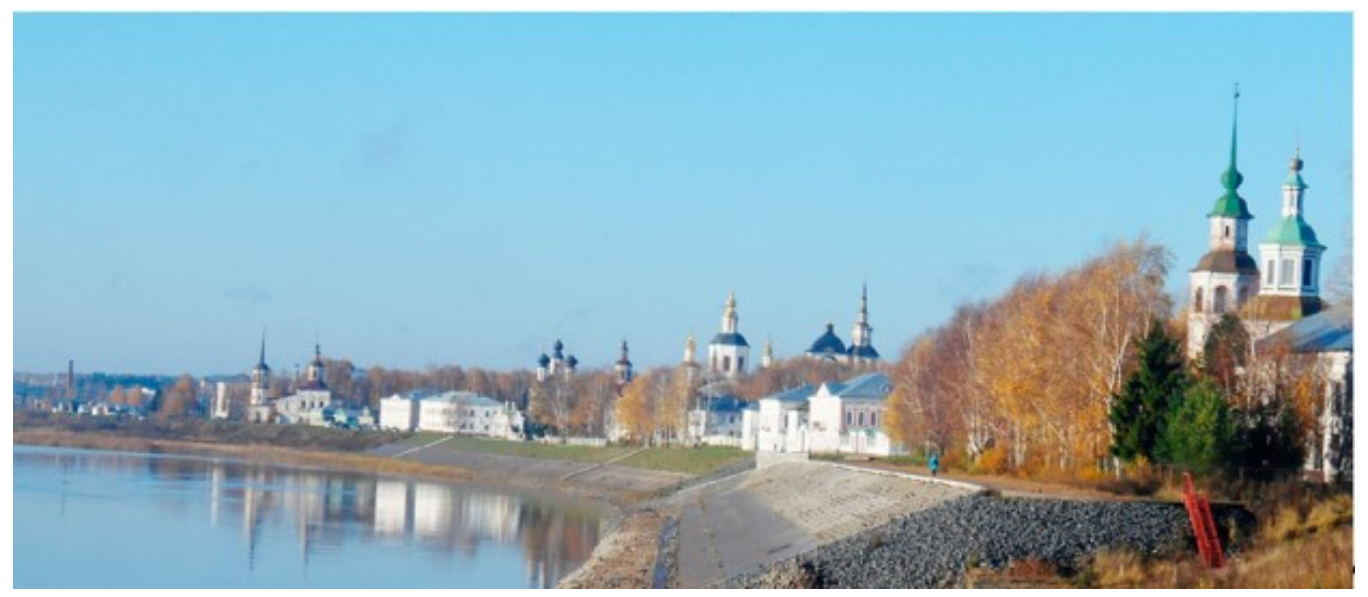

Рис. 31. Великий Устюг, набережная реки Сухоны

Основная проблема проекта - в его сезонности. Вотчина Деда Мороза работает на максимуме в новогодние праздники, обеспечивая до $90 \%$ турпотока, в остальное время туристов здесь немного и объект простаивает, вследствие чего страдает качество туристического продукта и уровень обслуживания.

Целесообразным для туроператоров представляется разработка в Великом Устюге турпродуктов, ориентированных на другие сезоны. Также необходимо участие государства, чтобы создать масштабные событийные мероприятия для привлечения туристов в межсезонье и повышения 
привлекательности города и его окрестностей. Для этого есть необходимые предпосылки: это традиционный купеческий город с красивой набережной, множеством старинных храмов и исторических зданий. Надо создавать новые бренды и аттракции, привлекать внимание к истории купечества и не останавливаться только на бренде «Дед Мороз» [94].

\subsection{3. Тотьма}

Наиболее успешный опыт по созданию новых аттракций и активному взаимодействию музейно-туристической сферы с местными сообществами в малом историческом городе российской глубинки накоплен в Тотьме. Город входит в число 50 малых городов России, особенно привлекательных для туристов, ввиду выгодного географического положения и высокой сохранности множества памятников как церковной, так и гражданской архитектуры (рис. 32). На территории города находится 60 памятников архитектуры, объектов культурного наследия федерального и регионального значения. К сожалению, далеко не все интересные исторические здания имеют охранный статус.

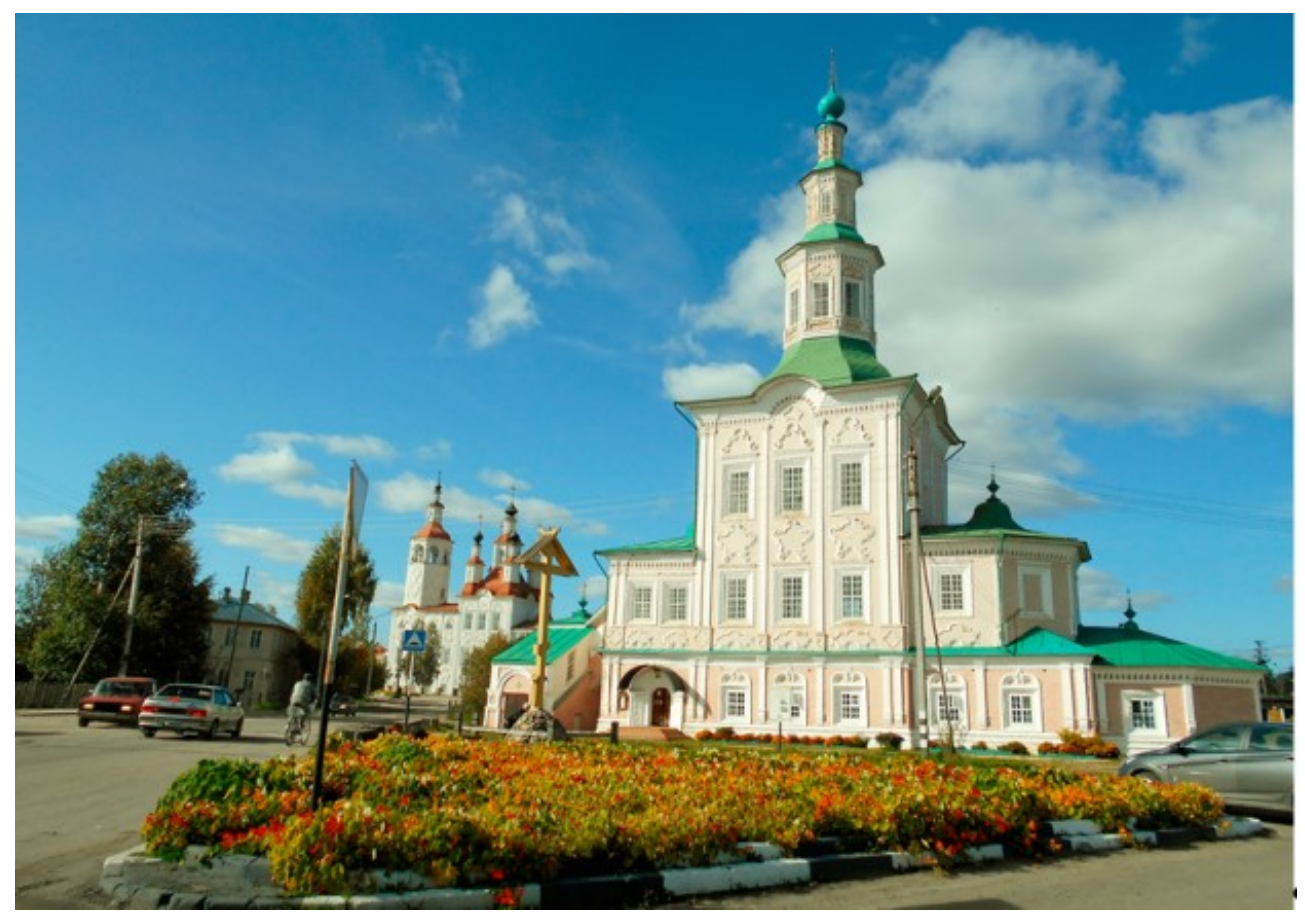

Рис. 32. Тотьма. Церковь Рождества Христова

В отличие от крупных городов России, в которых отмечается деградация городской среды со сносом исторических зданий и превращением их в безликие города-парковки, Тотьма сумела сохранить локальную идентичность, самобытность и целостность архитектурно-исторической среды. Туризм для города является одним из основных факторов устойчивого социокультурного развития в целях повышения качества жизни местных жителей.

Архитектурное наследие Тотьмы представлено так называемым тотемским барокко, классицизмом, русским стилем и эклектикой. Основу 
средовой исторической застройки составляют старинные деревянные дома, украшенные кружевными резными наличниками и ажурными дымниками. Наиболее целостная архитектурно-историческая среда сохранилась на Сретенской (Советской), Белоусовской, Почтовой (Ленина), Петропавловской (Володарского) улицах, а также в Рыбачьей Слободе (Савино).

При этом в Тотьме, как и в большинстве малых исторических городов России, остро стоит проблема с сохранением культурного наследия и аутентичного облика из-за несовершенств законодательства по охране памятников и недостатка средств на их содержание. Сейчас нет эффективно действующего механизма защиты архитектурных памятников и сложившейся исторической среды. Тотьма - историческое поселение федерального значения. В нем должны быть правила землепользования и застройки (ПЗ3) в границах исторического поселения. Если границ исторического поселения нет, то окраины застраиваются бессистемно, въезды в город перестают выглядеть привлекательно, на исторических зданиях постепенно появляются пластиковые окна, профнастил, металлочерепица. Для потенциальных инвесторов, готовых реставрировать исторические здания, целесообразно установить определенные преференции, позволяющие им купить дом-памятник по символической цене, а затем по согласованию с региональным комитетом по охране памятников его реставрировать [97].

В 2019-2020 гг. Тотьма впервые приняла «Том Сойер Фест» - фестиваль восстановления исторической среды силами волонтеров и спонсоров. Для реставрации были выбраны деревянные исторические здания на улице Садовой и в Речном переулке. К реставрации местных памятников архитектуры можно также привлечь общественный фонд сохранения исторического наследия Ильи Варламова «Внимание».

Тотьма является одним из самых «брендовых» городов России. В городе развиваются несколько исторических туристских брендов, среди которых наиболее привлекательны для туристов: «Соль земли русской», «Город купцов и мореходов», «Город тотемского барокко», «Тотьма - город черной лисы», «Тотьма — город музеев» и «Настоящий тотемский продукт» [98].

Бренд «Тотьма - соль земли Русской» документально закреплен как товарный знак. Тотьма считается родиной русского солеварения. Город стал одним из инициаторов создания Ассоциации соляных городов России, в которую вошли также Солигалич, Сольвычегодск, Соликамск, Соль-Илецк и поселок Некрасовское. Город также включен в межрегиональный туристский проект «Солью единой» (Сольвычегодск - Тотьма - Солигалич) [99]. Между Солигаличем и Тотьмой всего 130 километров. Для дальнейшего развития данного проекта необходимо завершить строительство небольшого участка автодороги Солигалич - Тотьма длиной 12 километров. С постройкой дороги открывается круглогодичный туристический кольцевой автомобильный маршрут из Москвы, Санкт-Петербурга через исторические города Костромской области в Тотьму и далее в Великий Устюг и Сольвычегодск.

Среди туристов, посещающих Тотьму, преобладают экскурсионные группы из Москвы, городов Вологодской области, соседних Архангельской и Кировской областей. В Тотьму едут со всей России вплоть до Дальнего Востока, европейских стран, Америки, Китая. Наряду с летним сезоном, Тотьму 
посещает немало туристов с детьми в зимний период, останавливающиеся в городе на полпути от Вологды до Великого Устюга — родины Деда Мороза [100].

Активное участие в приеме туристов и развитии туристской отрасли принимают «ТотьмаТур», Тотемское музейное объединение, фонд общественных инициатив «Соль Земли», Школа путешественников Фёдора Конюхова. Петровская детская художественная школа возрождает традиции старинной Петровской ремесленной школы по изготовлению продукции традиционных народных промыслов. Имеет перспективу возрождение игрушечного промысла, в старину Тотьму называли русским Нюрнбергом, городом игрушечников.

Наиболее перспективными видами туризма в городе являются: культурно-познавательный, промышленный, событийный, велосипедный, гастрономический, паломнический, социально ответственный (волонтерство), водные виды туризма.

Тотьма всегда привлекала к себе паломников. Они едут, чтобы прикоснуться к мощам преподобного Феодосия Суморина. В городе сохранилось одиннадцать исторических храмов XVIII-XIX вв. (включая монастырские храмы и собор в Варницах). Семь из сохранившихся храмов представляют собой классические образцы самобытной архитектурной школы тотемского барокко либо имеют черты этого стиля (рис. 33). Основным украшением тотемских церквей, построенных на средства местных купцовмореходов, являются уникальные орнаменты на фасадах - картуши (или клейма). По итогам Всероссийского мультимедийного конкурса «Россия 10» тотемские картуши вошли в двадцатку лучших из более чем восьмисот достопримечательных объектов страны, а также стали абсолютными лидерами среди объектов показа Вологодской области [99].

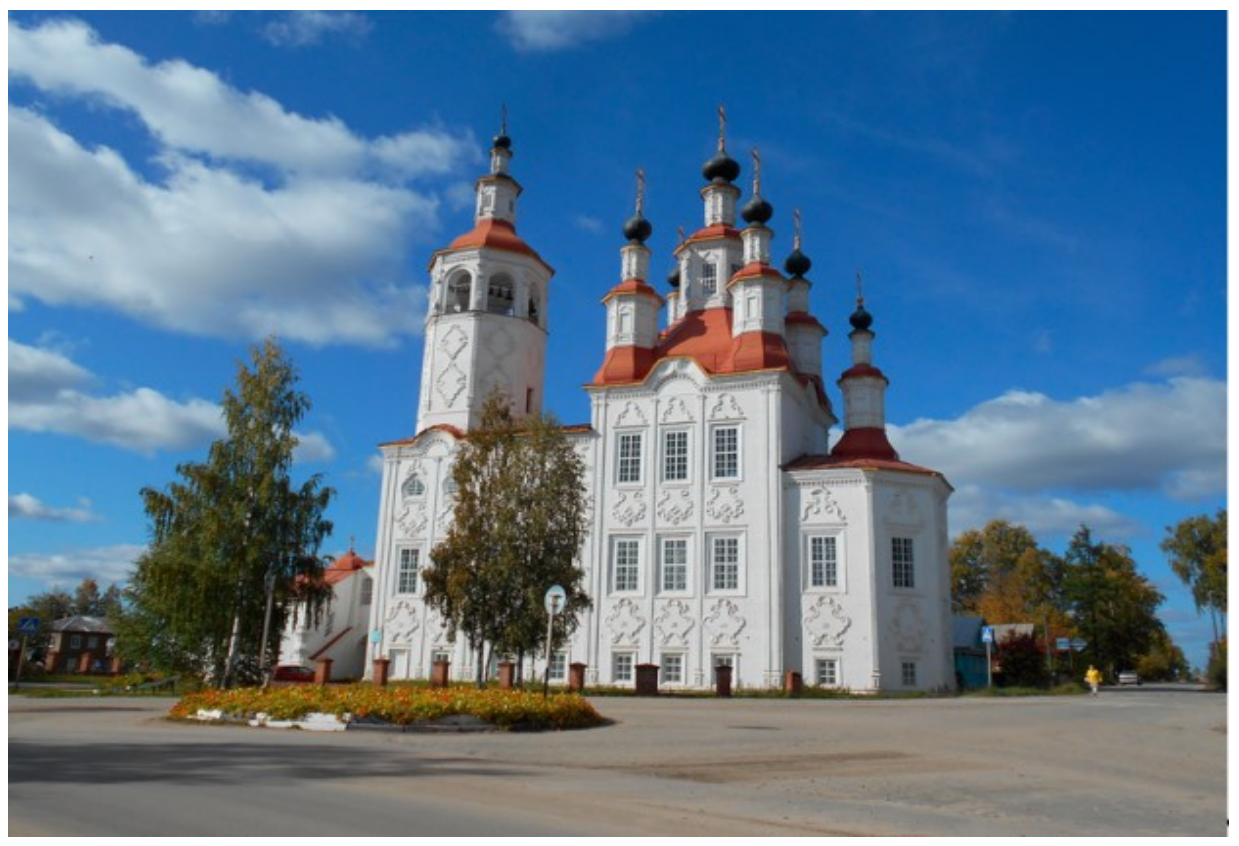

Рис. 33. Тотемское барокко. Входоиерусалимский храм 
Практически все туристы отмечают особую провинциальную атмосферу душевного комфорта Тотьмы, которая складывается из нескольких компонентов: тишина, спокойствие, уют и малоэтажность. К этому можно еще добавить благоприятную экологическую обстановку, слабое автомобильное движение, отсутствие глухих заборов, чистоту и опрятность улиц и дворов, приветливость и открытость местных жителей. В этом плане Тотьма особо привлекательна для жителей мегаполисов и столиц. В результате на задний план отходят существующие бытовые неудобства, разбитые дороги, невысокий уровень сервиса и инфраструктурная неблагоустроенность [101, с. 165-169].

Одним из ключевых факторов в жизни современной Тотьмы, драйвером его социокультурного развития является музейное объединение, отметившее в 2015 г. свой столетний юбилей и ставшее одним из крупнейших музейных комплексов Северо-Запада страны. Тотемское музейное объединение стало победителем Всероссийского конкурса «Интермузей - 2019» в номинации «Лучший проект, направленный на межрегиональное взаимодействие» с проектом Школы музейного развития «За границами столиц» [102].

С показателем в шесть музеев на 10 тыс. человек постоянного населения Тотьма является одним из городов-лидеров в России по музеефикации на душу населения. Посещаемость музеев города ежегодно составляет более 50 тыс. человек [98]. Вместе с тем, по мнению директора Тотемского музейного объединения Алексея Новоселова, муниципальный статус музейного объединения не позволяет ему стать по-настоящему градообразующим предприятием и играть ту роль, которую, допустим, играет КириллоБелозерский музей-заповедник федерального значения в Кириллове. Пропасть в возможностях финансирования федеральных и муниципальных музеев огромна.

Несмотря на проблемы с бюджетным финансированием, в Тотемском музейном объединении за последние пять лет удалось сделать немало. Привлечено порядка 18 млн рублей сторонних средств из различных грантовых источников. На эти средства были выпущены новые краеведческие издания и путеводители, обновлены музейные экспозиции. Реализован новый проект - креативное пространство «АнтреСОЛЬ», которое работает как для туристов в качестве краеведческой интерактивной экспозиции по солеварению в Тотьме, так и для местных жителей в качестве места досуга. Появились новые форматы взаимодействия с аудиторией - спектакли по анфиладам музейных залов, дискуссионные фокус-группы, квесты, интерактивные программы [103]. Например, проводится экскурсия с квест-игрой «В поисках клада черной лисы». Одна из стратегических задач музея состоит в создании аутентичного привлекательного образа города.

Тотьма в 2018 г. официально стала первым самым красивым городком России, принятым в Ассоциацию самых красивых деревень и городков России (АСКДГР). Благодаря грамотной маркетинговой работе креативных сотрудников местного музейного объединения, администрации города по повышению привлекательности города и продвижению туристского потенциала, Тотьма в настоящее время значительно преобразилась в инфраструктурном плане и превратилась в аттрактивный туристский центр. Только за последние четыре года реализованы проекты «Кольцо исторической памяти» и «Культурный квартал», направленные на создание новых аттракций и комфортной городской среды, выход музея в городское пространство. 
На финансовые средства краудфандинга и гранта благотворительного фонда Елены и Геннадия Тимченко «Культурная мозаика малых городов» в историческом центре города появились новые общественные пространства, арт-объекты и скульптуры, посвященные местным аутентичным брендам, открыт новый музей (рис. 34,35 ). На улицах города появились информационные таблички с историческими названиями улиц и стенды с информацией об утраченных и существующих памятниках архитектуры на русском и английском языках с фотографиями и туристской навигацией.

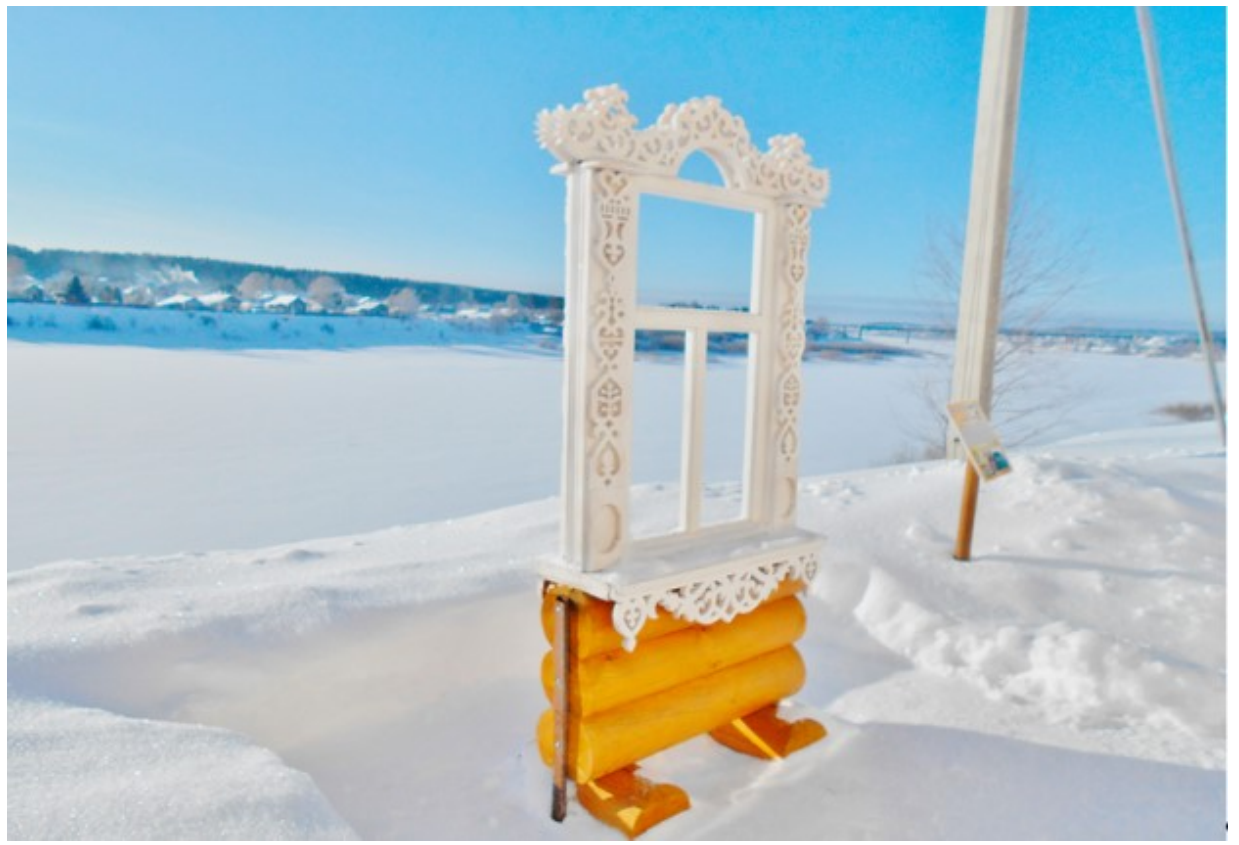

Pис. 34. Тотьма. Арт-объект «Резное окно»

Местные жители, генерирующие одну за другой проектные идеи и привлекшие на территорию Тотьмы более сорока миллионов рублей за три последних года без какого бы то ни было бюджетного финансирования, горячо любят свой город [103]. С целью вовлечения местных сообществ в социокультурные и краеведческие проекты, в городе организован фонд общественных инициатив «Соль Земли».

Практически каждый год в городе появляются новые аттракции и креативные общественные пространства. В 2019 г. в рамках федерального проекта «Формирование комфортной городской среды» открыты: новая пешеходная улица — бульвар Дилакторских — длиной 700 метров и арт-объект «Галиот». А в 2020 г. закончено обустройство исторической набережной Ивана Кускова с амфитеатром и арт-объектом «Народная полоскальня».

Общий поток посетителей Тотьмы и района постепенно растет, за 2019 г. он составил 132 тыс. человек. Количество туристов, останавливающихся в гостиницах, составило 46 тыс. человек. Всего в городе действует пять гостиниц и один гостевой дом. В течение 2019 г. произошли важные для Тотьмы изменения в инфраструктуре туризма. Открыты новые объекты размещения и общественного питания [102]. В основном кратковременное пребывание туристов в Тотьме не позволяет приносить существенный доход в местную казну. 


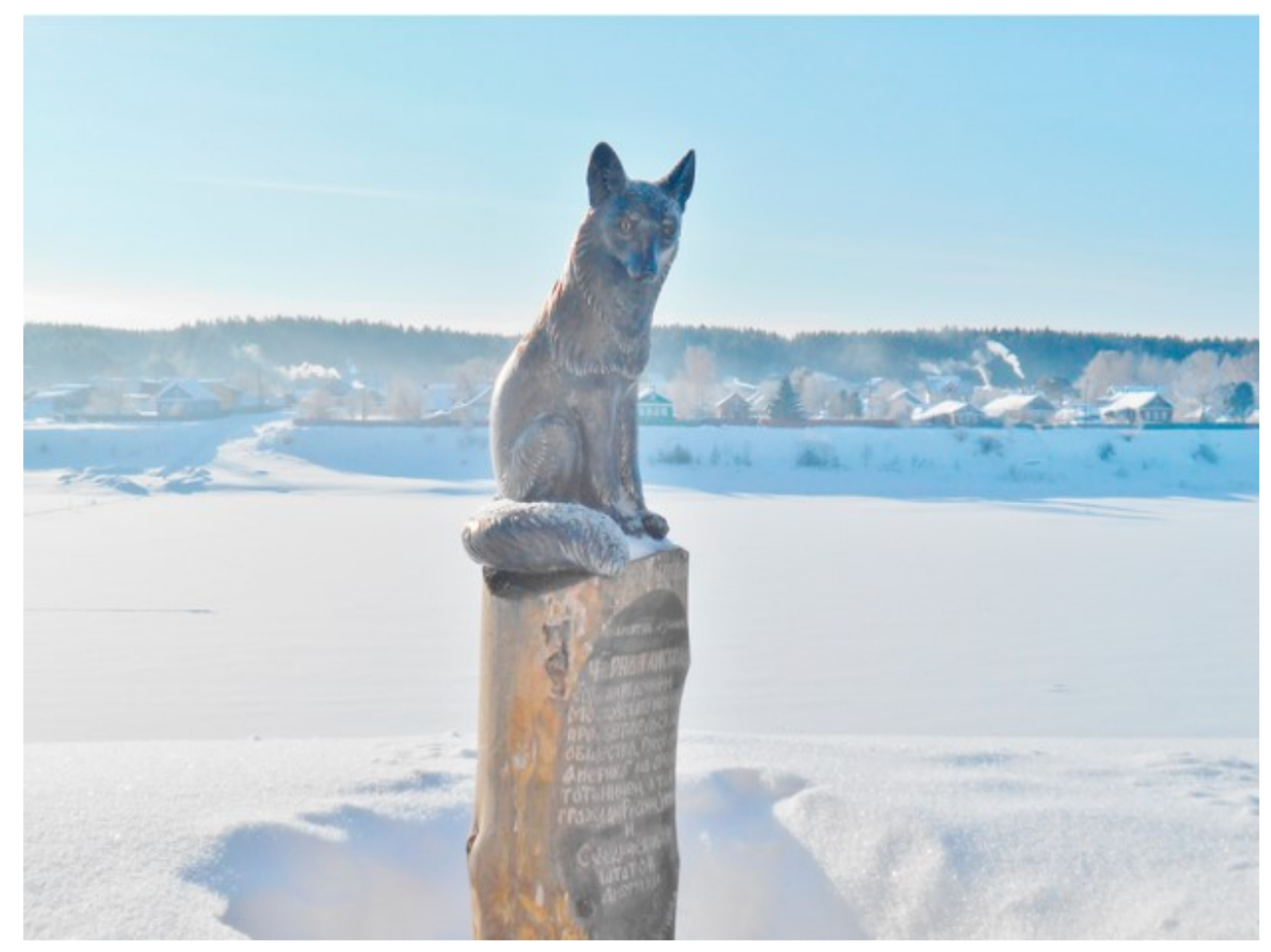

Рис. 35. Тотьма. Памятник черной лисице

Основной проблемой в сфере туризма является транспортная доступность Тотьмы. В черте города уже нет круизного и пассажирского судоходства с причалом, железной дороги, быстрой доступности к какому-нибудь крупному городу. Тотьма — «оазис» посреди лесов, поэтому здешний турист довольно-таки нишевой. Местные предприниматели пока не готовы предложить проживание большим группам - окупаются только мини-отели, хостелы, небольшие гостевые дома, зачастую с дополнительным сервисом: кафе, автомойкой, помещениями, сдаваемыми в аренду. Это позволяет выживать в мертвый сезон, когда турпоток минимален (октябрь, ноябрь, февраль и апрель - самые проблемные в этом плане месяцы, поэтому именно в это время организуются событийные мероприятия, конференции, чтобы помогать гостиницам массовой загрузкой) [103]. Для привлечения групп организованных туристов необходима более качественная инфраструктура. В историческом центре Тотьмы практически нет частных гостевых домов.

Есть также проблема с общественным питанием для самостоятельных туристов. Несмотря на достаточное количество кафе в маленьком городе, многие из них бывают закрыты вечером, а в выходные дни уходят на спецобслуживание.

Тотьма входит в Союз русских ганзейских городов нового времени. Город имел важное торговое значение - единственный водный путь из России в Европу долгое время проходил именно здесь. Тотьма включена в туристские маршруты: «Путями Прокопия Праведного», «Серебряное ожерелье России» и «Ганзейские дороги России» [104].

В городе набирает популярность водный туризм. Организован водный маршрут по активному туризму «Сплавы на катамаранах и байдарках по реке 
Сухона», проводится праздник - Сухонская регата. Проводятся водные экскурсии по реке Сухоне на катерах «Удача», «Дорогой Петра I» до камня Лось и «Тайны Дедова острова». Популярный весенний круизный маршрут Вологда - Тотьма - Великий Устюг по реке Сухоне на теплоходе прекращен в 2014 г. по причине сильного обмеления реки, речная пристань демонтирована.

Успешное развитие сельского туризма доказывают сегодня деревни Тотемского района Устье («Усть-Печеньга - сосновая река»), Погорелово («Тропою Вассиана Тиксненского») и село Никольское - духовная родина поэта Николая Рубцова. Все они реализуют разнообразные культурнопознавательные программы и паломнические туры. В сельской местности открыто четыре гостевых дома.

Около Тотьмы на базе бывшего детского лагеря создана Школа путешественников Федора Конюхова. Здесь открыт дом-музей великого путешественника. Школа путешественников реализует программы по развитию детско-юношеского и водного туризма, в том числе проект «Из Тотьмы в Калифорнию».

Тотемскую кулинарную продукцию сегодня стараются приобретать гости города в магазинах и на ярмарках. Особую популярность среди туристов получили местные гастрономические бренды - сувенирные пряники, щербет, мармелад, тотемский торт и пирожки-пресники.

Основными событийными мероприятиями Тотьмы являются: ярмарки «Преображенская» и «Настоящий тотемский продукт», День Русской Америки, день города, кулинарный фестиваль «Морошка», фестиваль «Рубцовская осень», международная гонка на собачьих упряжках «Русский Север» [100].

Для привлечения туристов в Тотьму целесообразно создание новых объектов показа и общественных пространств, в том числе методом тактического урбанизма. Например, организация объектов уличного стрит-арта (муралов), смотровых площадок, креативных инсталляций, открытие новых музеев (черной лисы, дома-музея художника Вахрушова). В настоящее время в Тотьме создается дом традиций и ремесел «Морошка» с сувенирной лавкой, где можно будет приобрести продукцию тотемских ремесленников. Также можно предложить создание в Тотьме парка-музея под открытым небом соляных городов-побратимов Тотьмы, где в миниатюре могут быть представлены макетысимволы исторических солепромышленных поселений России.

Основным средством передвижения по городу в перспективе может стать велосипед, тем более что в Тотьме местным изобретателем Сергеем Лукьяновым налажено производство уникальных велосипедов-рикамбентов «Тотьмич» и «Гагарин». Летом 2020 г. в Тотьме заработал музейный велопрокат «Я буду долго гнать велосипед». Велопутешествие по Тотьме можно совершить в формате оригинального квеста по городу [98]. Ввиду малоинтенсивного автомобильного движения на улицах города, отдельной велоинфраструктуры типа велодорожек делать не требуется.

В 2020 г. в рамках общественных музейных проектов «Соль Земли» и «Труба зовет» в пригородном историческом посаде Варницы (бывшее Старое Усолье) на месте бывшего солеваренного завода создается новый туристский маршрут, который позволит всем желающим познакомиться с солепромышленным наследием Тотьмы. На средства президентского гранта на пешеходном маршруте появились деревянные мостки и мостики, арт-объекты 
и смотровые площадки для отдыха, специальное сооружение над одной из рассолоподъёмных труб, информационные стенды и таблички.

Освоение территории бывшего сользавода планируется продолжить. В историческом центре промышленной зоны будет заложен археологический раскоп, будет строиться варница, также появится амбар - помещение, где можно будет принимать тургруппы, проводить мастер-классы и другие мероприятия. Будет воссоздан старинный колодец - «журавль». Наконец, планируется появление информационного комплекса под открытым небом об истории деревни Варницы.

Частью туристского маршрута является «Соляной дворик» - площадка под открытым небом на внутренней территории Тотемского музейного объединения, куда начиная с 1990-х гг. свозили артефакты, связанные с соляным промыслом, предметы Тотемского солеваренного завода, существовавшего до конца XIX в. В «Соляном дворике» планируется воссоздать часть соляного промысла, обустроить мини-варницу, где можно самостоятельно выпарить соль. Другой объект турмаршрута - соляной склад-амбар, единственный из сохранившихся в Тотьме. Это деревянное сооружение середины XIX в. требует консервации и реставрации, поэтому туристам его показывают снаружи [105]. 


\section{6. ИСТОРИЧЕСКИЕ ПОСЕЛЕНИЯ ЕВРОПЕЙСКОГО СЕВЕРА РОССИИ. ПРОБЛЕМЫ ТУРИСТСКОГО ОСВОЕНИЯ КУЛЬТУРНО- ИСТОРИЧЕСКОГО НАСЛЕДИЯ УНИКАЛЬНЫХ ТЕРРИТОРИЙ}

\section{1. Исторические города}

На территории Русского Севера расположено 22 исторических города регионального значения, из них пять малых городов, имеющих статус исторического города федерального значения. В сокращенный перечень 2010 г. особо ценных исторических городов России вошли малые города Русского Севера, сохранившие большую часть старинной застройки: вологодские города Белозерск, Тотьма и Великий Устюг, архангельские - Каргополь и Сольвычегодск. Такие крупные города, как Архангельск, Череповец и Вологда, потеряли официальный статус исторического города.

Самым посещаемым региональным центром Русского Севера является древняя Вологда, за последние пять лет турпоток в культурную столицу Русского Севера вырос на $70 \%$ в результате активного развития туристской инфраструктуры и грамотной маркетинговой политики по продвижению города на туристском рынке. Планировалось, что к 2020 г. туристский поток в областную столицу должен увеличиться до 1 млн человек, что обеспечило бы дополнительный приток денежных средств в бюджет города в размере 10 млрд рублей [106, с. 206-211].

По экономическим расчетам, один турист в среднем оставляет в Вологде как минимум 10 тыс. рублей. Это порядка 3,5 тыс. рублей за сутки в отеле, 2 тыс. рублей в кафе и ресторанах, 1 тыс. рублей при покупке сувениров и 3,5 тыс. рублей при посещении экскурсий и музеев. Если в год в Вологду приезжает 700 тыс. туристов и экскурсантов, а $30 \%$ из них остается минимум на сутки, получается, что инвестиции в экономику города составляют не менее 2 млрд рублей. Из 700-800 тыс. туристов в год $70 \%$ - экскурсанты, $30 \%$ - туристы. Больше половины гостей останавливается в городе с деловой целью, 23 \% туристов - люди, которые едут в Вологду, чтобы познакомиться с городом, его архитектурой и историей (рис. 36). Еще порядка $21 \%$ туристов приезжают на событийные мероприятия [107].

Вызывает обеспокоенность проблема сохранения одного из основных брендов Вологды - резного деревянного зодчества. Вместо снесенных и сгоревших деревянных памятников архитектуры вырастают, как правило, безликие строения из стекла и бетона, в лучшем случае так называемые муляжиноводелы, лишь имитирующие внешний облик исторических зданий. В столице Поморья - Архангельске - также отмечается тенденция к сносу и утрате средовой деревянной застройки.

Лучшими примерами успешного развития туризма в малых исторических поселениях Русского Севера, наряду с Великим Устюгом, являются Тотьма, Кириллов, Белозерск и Яренск. Здесь растет туристский поток, создаются новые рабочие места, привлекаются дополнительные инвестиции, пополняется доходная часть местных бюджетов, разрабатываются новые событийные мероприятия. 
Специфическая проблема малых исторических городов Русского Севера состоит в значительной доле стареющего деревянного фонда ценной средовой застройки, утрата которой и соответствующее изменение городской исторической среды означают размывание идентичности поселения. Сфера культурно-исторического наследия (охрана памятников архитектуры и сохранение аутентичного облика) - основная проблема малых городов с точки зрения культуры и туризма.

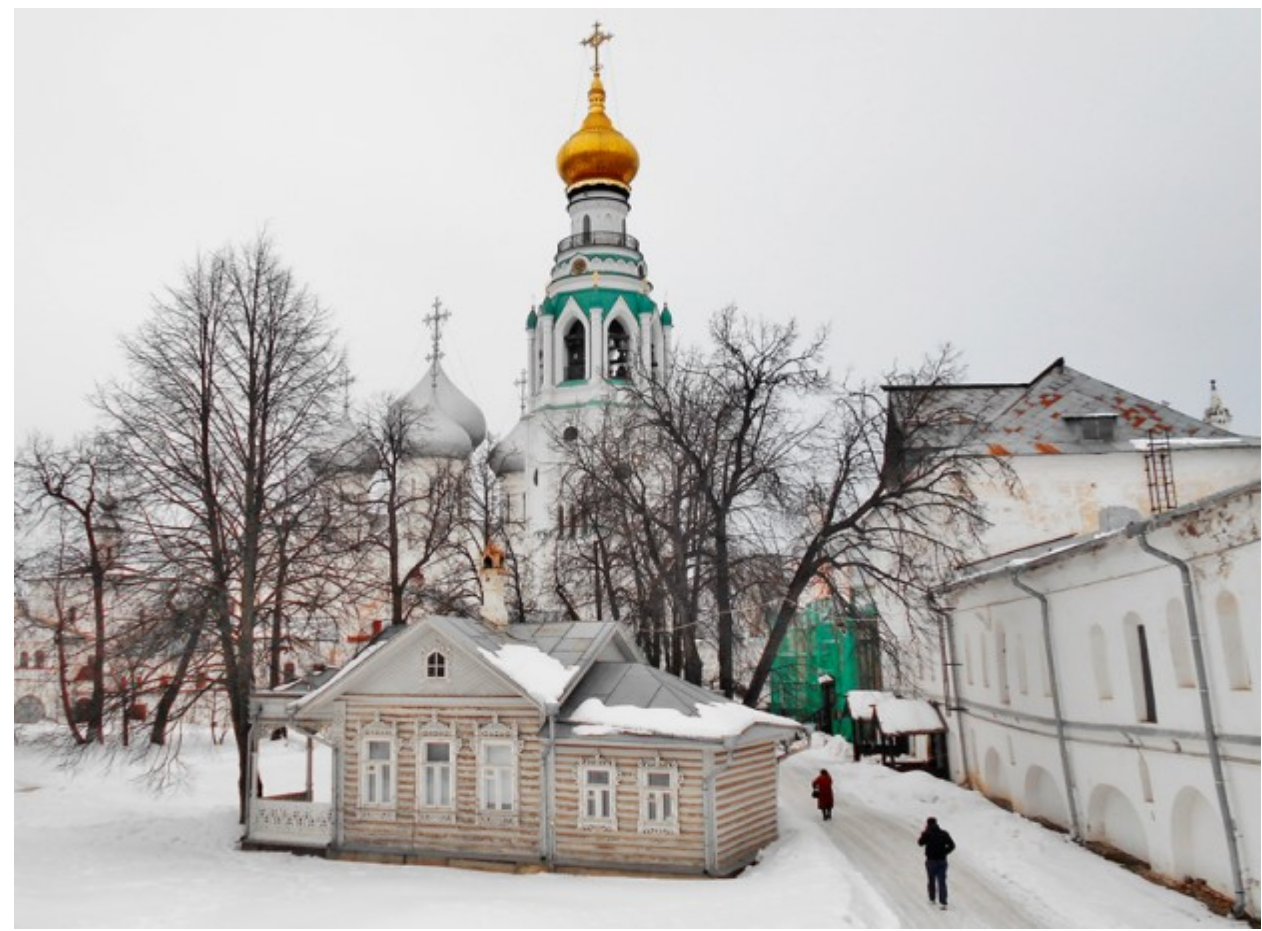

Рис. 36. Вологда. Кремль

Среди малых городов Архангельской области следует особо отметить Каргополь, Вельск и Сольвычегодск, в которых, несмотря на небольшой туристский поток, активно развивается система туристско-информационной навигации в историческом центре возле основных объектов показа (рис. 40). Город-музей Каргополь - единственный из городов Русского Севера, принятый в Ассоциацию малых туристских городов России, место проведения ярких круглогодичных фестивалей и праздников. Город посещает ежегодно около 10 тыс. туристов (рис. 38, 39).

Каргопольский музей подготовил новый брендовый проект «Каргополь - родина президента Русской Америки А. Баранова», в рамках которого предполагается в исторической части Каргополя, где сохранились храмовые белокаменные ансамбли и часть гражданской застройки конца XIX — начала $\mathrm{XX}$ вв., создать культурно-деловой комплекс. Наиболее значимым объектом данного проекта является музей каргопольца, президента Русской Америки Александра Баранова. Также планируется создание мемориального музея-квартиры каргопольского художника Геннадия Кулишова «Дом художника» и выставочно-торгового комплекса «Гостиный двор» [108]. 
Исторический центр древнего Вельска пополняется новыми культурными объектами показа. Открыт парк деревянных скульптур фестиваля «Древо жизни», а на центральной площади создан пешеходный музейный квартал. В 2018 г. открылся экспозиционно-выставочный комплекс «Музей домовых художественных росписей Поважья» в перевезенном из глубинки памятнике деревянного зодчества, доме Кичева.

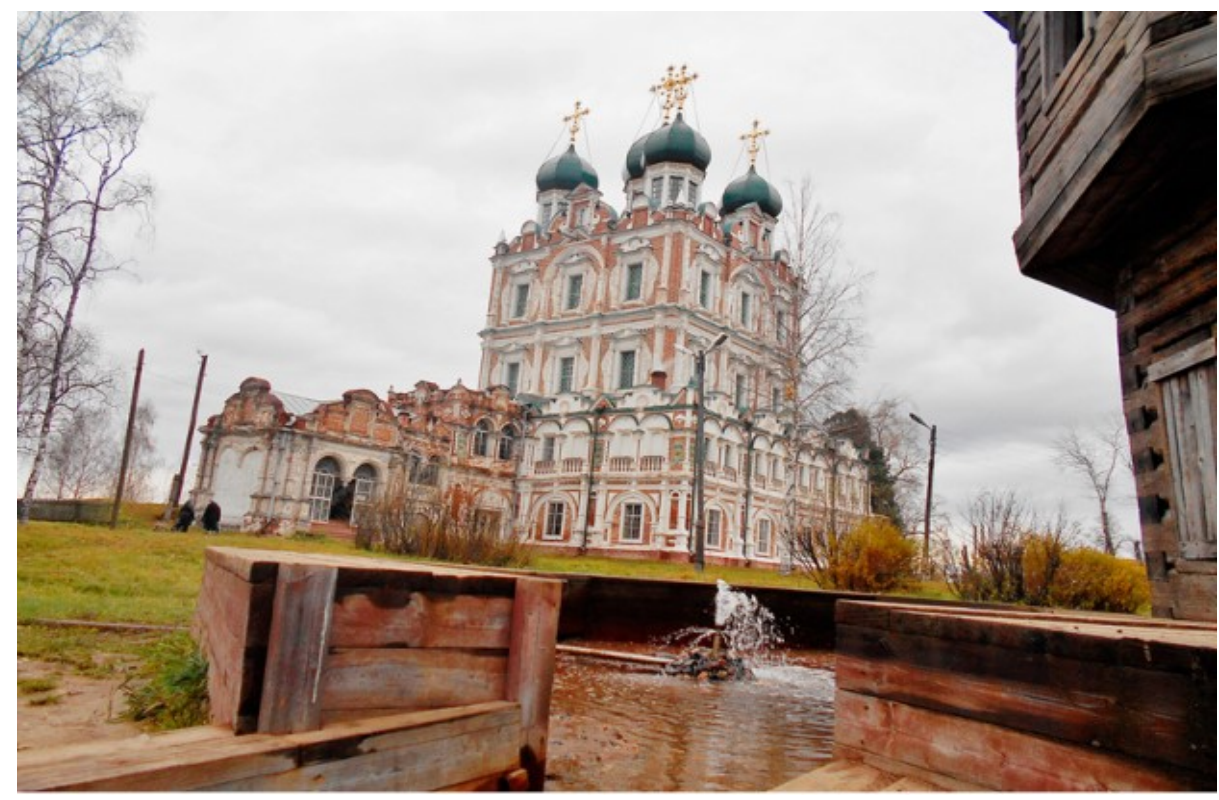

Рис. 37. Сольвычегодск. Введенский собор

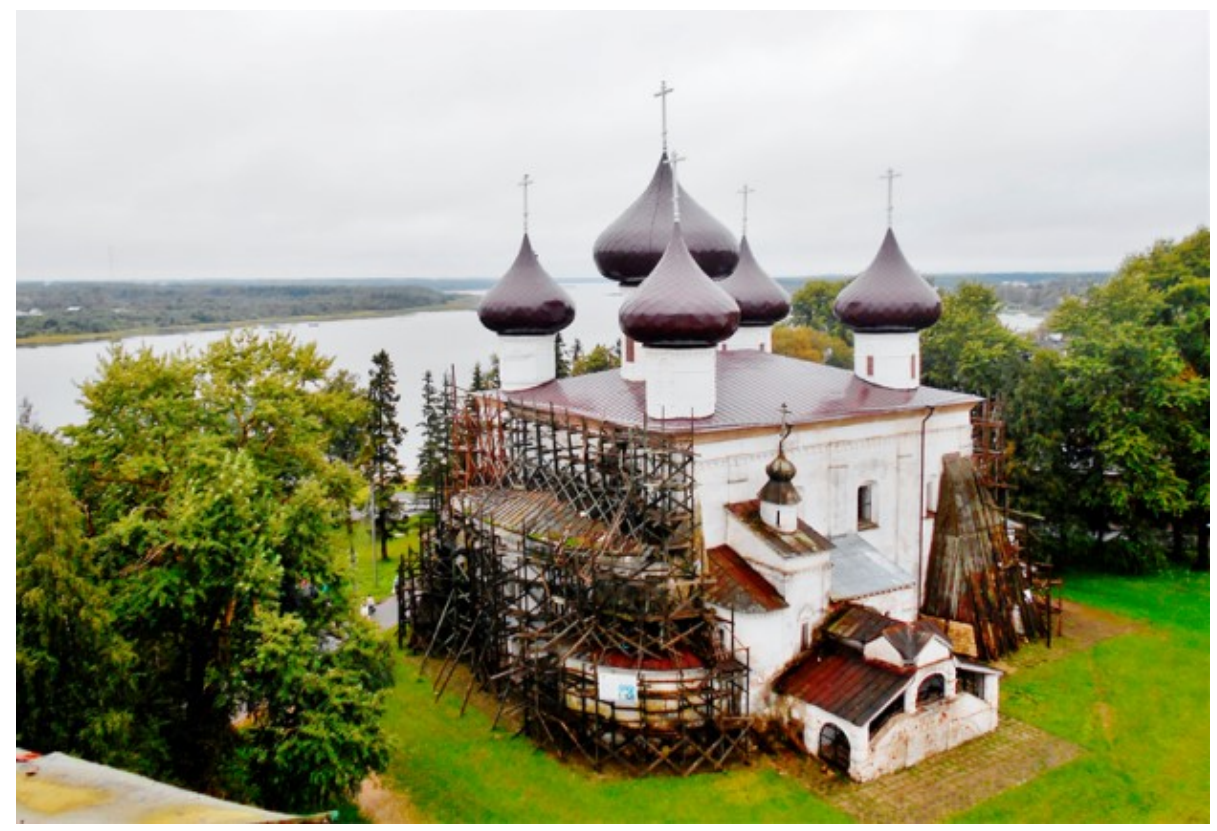

Рис. 38. Каргополь. Христорождественский собор 


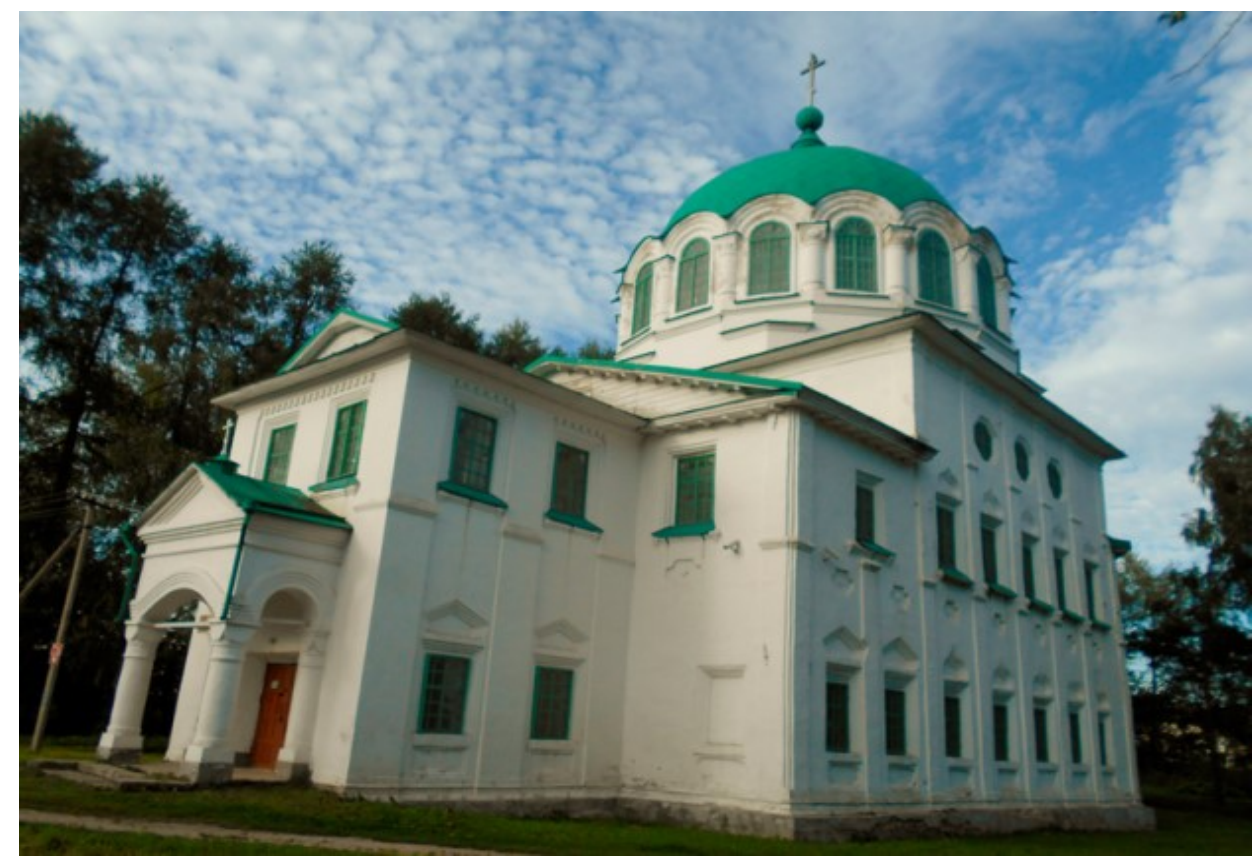

Рис. 39. Каргополь. Троицкая церковь

А в Сольвычегодске, одном из самых миниатюрных городов России с уникальным грязелечебным курортом и мощным культурным наследием, связанным с династией Строгановых, установлены информационные стенды об истории существующих и утраченных памятников архитектуры, создан парк скульптур фестиваля Козьмы Пруткова, открыт первый комфортный объект размещения - гостиница «Купеческая».

Бывший уездный городок Шенкурск привлекателен для туристов не только хорошо сохранившейся исторической застройкой, но и своим природным наследием - в черте города расположено несколько старовозрастных сосновых боров на холмистых берегах Ваги. Из-за этой особенности и разработан туристский бренд города — «Сосновые каникулы в Шенкурске».

Потенциальными кандидатами на вступление в АСКДГР являются малые городки Русского Севера, сохранившие аутентичные памятники архитектуры, самобытную культуру местных жителей и традиционную историческую среду обитания - Кириллов и Белозерск (рис. 40). В 2020 г. города-кандидаты Каргополь и Сольвычегодск уже были включены в ассоциацию. Каргополь в этом же году получил статус креативного города ЮНЕСКО среди творческих городов мира в области ремёсел и народного творчества. В России такой высокий статус, помимо Каргополя, имеют только два города - Ульяновск и Казань. Эта сеть объединяет города, в основе развития которых лежит творчество: декоративно-прикладное и народное искусство, музыка, дизайн, литература и гастрономия. Города, входящие в сеть ЮНЕСКО, определяют креативность и креативную экономику одним из приоритетных направлений в своем развитии. 


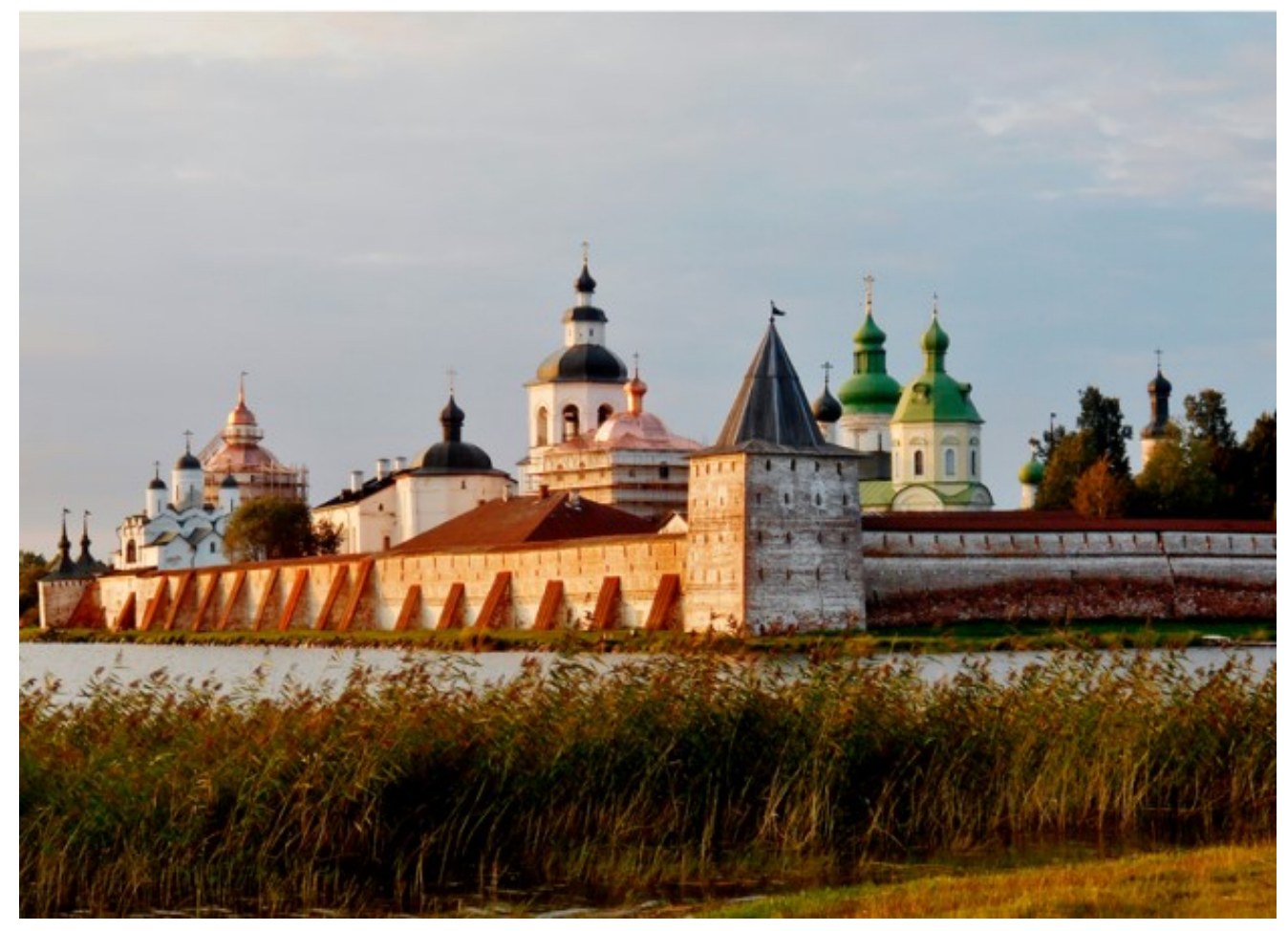

Рис. 40. Кирилло-Белозерский монастырь

Среди малых исторических городов Русского Севера на первом месте по посещаемости занимает Кириллов, принимающий около 360 тыс. туристов в год (из них 66 тыс. - иностранцы) в основном в рамках водного круиза по Волго-Балту - самого популярного туристского маршрута Европейского Севера. Экономический потенциал Кирилловского района на 45 \% формирует сфера туризма и услуг. Кириллов входит в тройку самых популярных у туристов малых городов России. В летний сезон ежегодно пристань Горицы принимает до 500 круизных теплоходов.

В федеральный проект «Сказочная карта России» занесено несколько резиденций Архангельской области. Наибольшую известность среди туристов набирают бренды бывшего уездного городка Яренска Ленского района «Родина Матушки Зимы» и «Брошу все, уеду в Яренск». Несмотря на транспортную удаленность Яренска, туристский поток в старинное село увеличился с 200 чел. в 2012 г. до 19 тыс. чел. в 2017 г. [106]. К сожалению, плачевное состояние большинства исторических зданий села не позволяет ему в ближайшее время рассчитывать на потенциальное включение в АСКДГР.

Малые города, особенно обладающие богатым историческим наследием, ждут простых и быстрых решений для своего развития, резкого увеличения числа туристов, а значит, роста доходов и занятости населения. Культурнопознавательный туризм - это база для экономического роста и возможность для устойчивого развития исторического города. Однако не стоит ожидать массового туризма в малых городах, особенно в городах с малоразвитой 
логистикой (например, Каргополе и Мезене). Туризм для таких городов не станет градообразующей отраслью, но может быть важным фактором развития.

Массовые туристы, как правило, выбирают наиболее доступные, оптимальные по соотношению цены и качества места для посещения. Любые успешные примеры развития туризма в северных городках связаны либо с сильным брендированием в основном с использованием федеральных ресурсов (например, Великий Устюг), либо с выгодным географическим положением (например, Кириллов) [109].

Каждый малый исторический город должен искать свои особые изюминки, которые могли бы стать опорными элементами в создании привлекательного образа локальной идентичности. Необходимо изыскивать какие-нибудь мелочи, которые могли бы стать брендовыми продуктами, символами города и которые являются специфичными или даже уникальными. Например, в Каргополе есть общественные полоскальницы. Это такие места, где до сих пор в речной воде полощут после стирки бельё, и для этого есть специально приспособленные строения. Абсолютно привычное дело для каргопольца, но совершенно необычное и интересное для туриста. Еще в Каргополе есть известная каргопольская игрушка и «сущик», особым образом сушеная рыба для приготовления ухи. Возможно, при хорошем маркетинге все эти артефакты могли быт стать товарным продуктом при условии увеличения туристского потока в город [110].

Очевидно, что для успешного развития экономика малого города может быть только многопрофильной. Тем более что форсированное развитие туризма и экономики впечатлений как доминирующей несет определенные риски для идентичности города. Малый город типа Каргополя может частично зарабатывать на лесопереработке, частично - на сельском хозяйстве, частично - на туризме (в основном внутреннем). Для устойчивого развития требуется то, что формирует внешний спрос на привлекательность города.

В малых городах уезжающую молодёжь можно замещать людьми (например, творческой интеллигенцией), которые, наоборот, готовы уехать из большого и дорогого города, где они уже испытывают дискомфорт от высокого темпа жизни. Чем их может привлечь Каргополь? Спокойствием, социальной однородностью, относительно невысокой стоимостью жизни. Возможен взаимовыгодный обмен: большому городу нужны активные, молодые люди, а маленькому - творческие, спокойные и зрелые. Это должна быть новая экономика услуг, связанная с другим кадровым составом, такой подход может оказаться эффективным для малых городов. Надо пытаться «продать» привлекательность уединения и локальности. Такие места, как Каргополь, могут это предлагать. В Каргополе возможно найти свой уникальный стержень, которым может стать общее увлечение историей, народной культурой, ремеслами или необычными обычаями [110].

В условиях практически полного разрушения реального сектора экономики малого исторического города только культура и креативная индустрия могут стать источником устойчивого развития. Этот фундаментальный разворот подразумевает, что результат деятельности будет иметь кумулятивный эффект, т. е. долго накапливаться до своего видимого проявления, причем увеличение доходов и благосостояния населения не будет происходить на первых этапах. Сложные условия Каргополья, 
связанные с социальной консервацией и экономической стагнацией вместе с окружающим природным ландшафтом и древней историей северорусских земель, делают наиболее перспективной идею заповедной северной России. Унификация интерпретации средневековой истории Каргополя как центра Русского Севера плюс унификация мифологем с последующим созданием музеев, школ искусств и ремесел, культурных аттракций являются самым базовым направлением разворота к культуре в существующих условиях [109].

Одна из серьёзных проблем малых городов - низкая социальная активность жителей, отсутствие эффективных технологий вовлечения населения в развитие города. Пример надо брать с Тотьмы, где сформировалось весьма активное инициативное сообщество на базе местных краеведов-музейщиков: и активисты, и бизнес активизировались, власть поддержала, все оказались связаны одной конкретной целью - выживание и развитие города за счёт социокультурной сферы и туризма. Эта синергия сработала и увлекла всё население города.

В исторических городах Русского Севера необходимо создавать комфортную городскую среду на основе развития дружелюбных общественных пространств и новых аттракций (пешеходных зон, набережных, велодорожек, музейного квартала, уличных арт-объектов и муралов, креативных инсталляций, малой городской скульптуры) и туристско-информационной навигации на базе установки указателей, информационных табличек и стендов с туристскими картами на исторических улицах и объектах культурного наследия. На стендах может быть отображена фотоистория или легенда, связанная с тем или иным памятником архитектуры. Возможна организация пешеходных тематических туристских маршрутов с нанесением их и объектов показа на информационные стенды с картами и даже цветная маркировка маршрутов на тротуарах (лучшие примеры - исторические поселения Пермского края, город Котельнич).

При проектировании городских велодорожек и велополос необходимо учитывать, что они должны быть безопасны и отделены от пешеходных дорожек и проезжей части. Для создания развитой велоинфраструктуры в городах и круглогодичного ее использования можно учесть положительный опыт развития велодвижения в северных европейских городах и российском Альметьевске, где катаются на велосипедах круглый год, включая зиму.

Качество проработки комфортной городской среды напрямую влияет на туристическую привлекательность города. Формирование профилей качественных общественных пространств - первый шаг к устойчивому развитию гостеприимных территорий, необходимый фактор возвратности турпотока. Основными принципами открытых общественных пространств являются: безопасность (от криминала и автомобилей), комфортность, наличие точек притяжения и активностей для местных жителей и туристов. Общественные пространства необходимо создавать там, где они будут реально пользоваться спросом, с хорошей доступностью для людей. На многолюдной пешеходной улице или набережной с насыщенными местами притяжения повышается инвестиционная и туристическая привлекательность, активно развивается малый и средний бизнес, снижается уровень уличной преступности.

При имеющихся проблемах с бюджетным финансированием в городах можно использовать инновационный метод тактического урбанизма при трансформации городских общественных пространств. Тактический 
урбанизм (англ. tactical urbanism) - относительно новое понятие, введённое в обиход в 2010 г. По сути, это обобщающий термин, который описывает методы по быстрому изменению городской среды при минимуме финансовых средств и активном участии местных сообществ. Городской дизайнер Эрик Рейнольдс описал данный термин следующим образом: «Легко. Быстро. Дёшево». Ведь идея тактического урбанизма - взять часть территории города и в максимально короткие сроки и с минимальными усилиями преобразить городскую среду [111].

Необходимо активное участие и заинтересованность местного населения в создании комфортной туристской городской среды, сохранении и эффективном использовании культурного наследия, а также его сотрудничество с турбизнесом и местными органами власти.

\section{2. Самые красивые деревни России - на Русском Севере}

На сегодняшний день Архангельская область является лидером среди субъектов РФ по количеству населённых пунктов, принятых в АСКДГР (шесть деревень и два города). В 2016 г. в неё вошла деревня Ошевенский Погост Каргопольского района, в 2017 г. - Кимжа Мезенского района, в 2018 г. - Кильца Мезенского района и Веркола Пинежского района (рис. 41). В 2020 г. статус самых красивых деревень России пополнили деревни Черевково Красноборского района и Зехнова (Кенозерский национальный парк). Поморские села Кимжа и Кильца стали первыми арктическими деревнями в ассоциации, так как Мезенский район входит в Арктическую зону РФ. Инаугурация деревень позволила увеличить поток туристов в Каргопольский район на $17 \%$, в Мезенский район - на $15 \%[112,113]$.

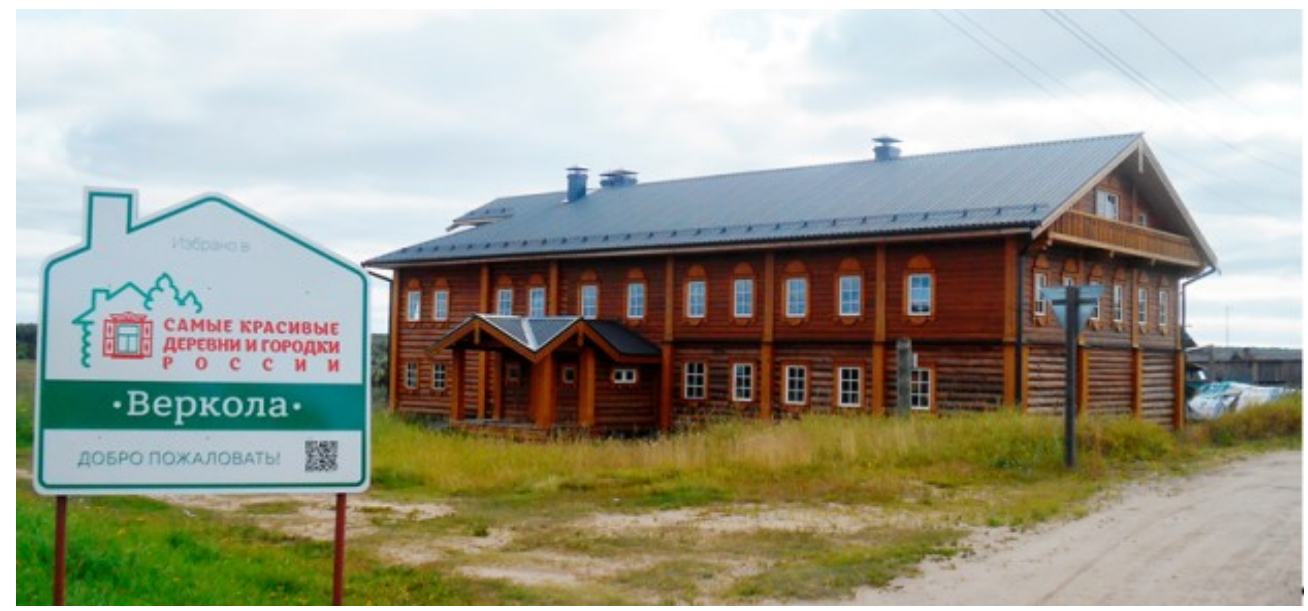

Рис. 41. Село Веркола

Мезенский район является хранителем природного и культурного наследия Русского Севера. Здесь сохранились ненарушенные природные ландшафты и старинные северные деревни, не утратившие настоящие поморские традиции и быт.

За последние десять лет количество туристов в арктической деревне Кимжа увеличилось в двадцать раз - до 1113 человек. Кимжа — это своеобразный естественно сохранившийся заповедник деревянного зодчества, 
природный, историко-культурный феномен, уникальное самобытное традиционное поселение, имеющее российское и международное значение. Культурный ландшафт Кимжы сохранился до настоящего времени практически в первозданном виде (рис. 42, 43).

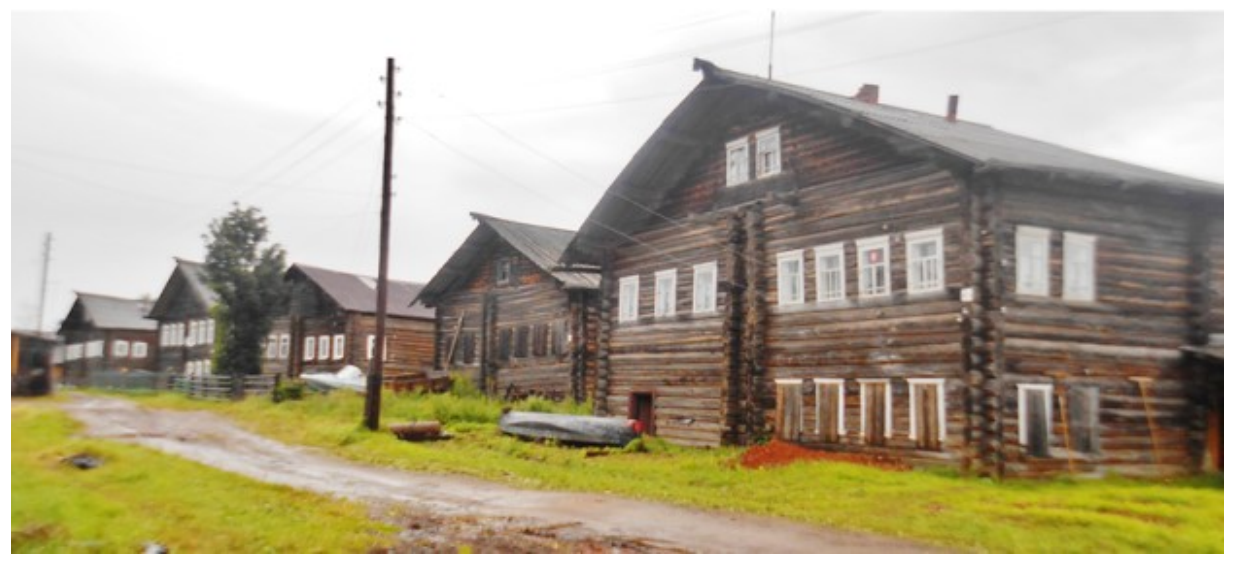

Рис. 42. Село Кимжа. Деревенская улица

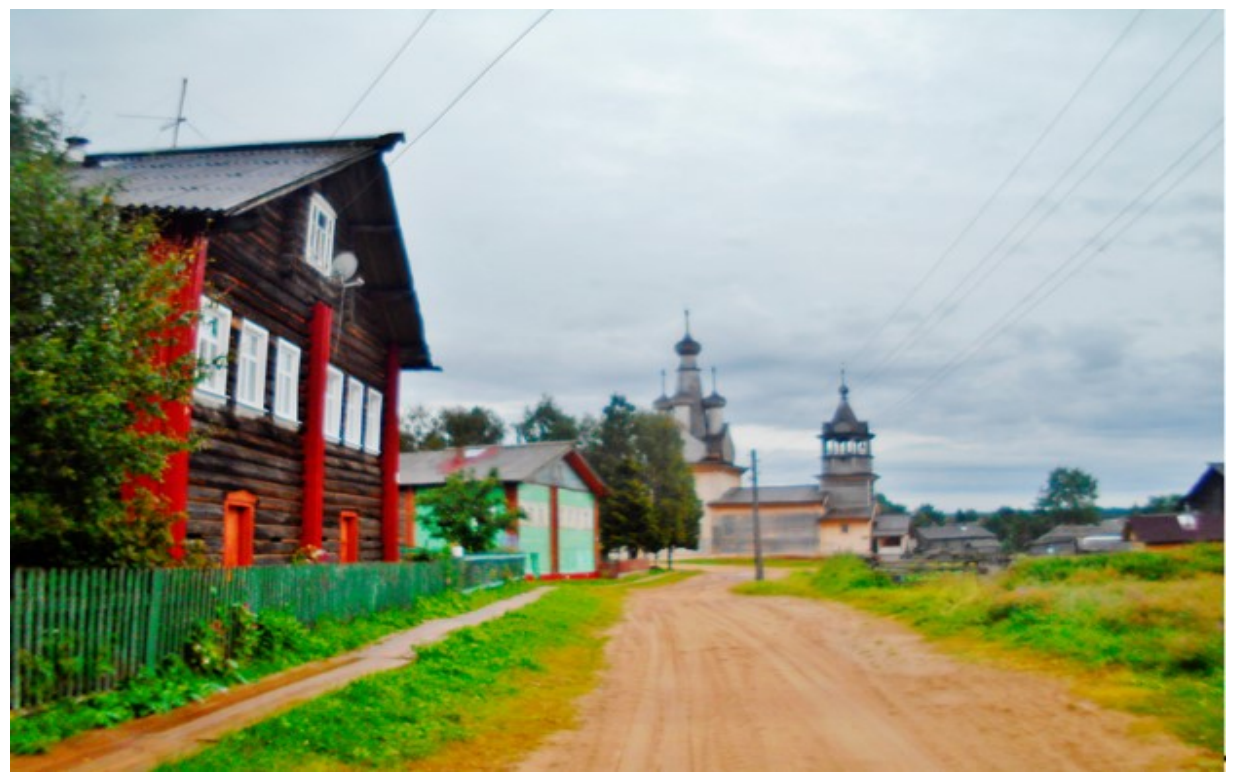

Рис. 43. Село Кимжа. Целостный культурный ландшафт

Сегодня Кинерма представляет собой уникальный комплексный памятник народного деревянного зодчества Карелии XIX в. карел-ливвиков. C 2001 г. действует международный проект по сохранению и возрождению деревень Ведлозерского края «Ведлозерье. Кинерма». Он направлен на сохранение и развитие исторической деревни Кинерма, включая сохранение архитектурного наследия, развитие местной традиционной культуры, создание условий для развития культурного туризма. По инициативе семьи Калмыковых, 
которые родились в Кинерме, создано частное предприятие, осуществляющее прием и обслуживание туристов. Среди объектов туристской инфраструктуры - отреставрированная баня по-черному, приспособленный под этнокультурный центр традиционный крестьянский дом, оформленная под столовую хозяйственная часть дома-комплекса, воссозданный исторический амбар для продажи сувенирной продукции, традиционный колодец, изгороди и т. д.

Деревня Кинерма является одним из семи чудес финно-угорского мира по версии сайта FINUGOR.RU. Местные жители активно занимаются сохранением карельской культуры и языка [115].

Ассоциация самых красивых деревень и городков России - это проект комплексного и устойчивого развития сельских территорий, направленный на повышение качества жизни местного населения, рассчитанный на активных людей, которые чтут свои традиции и самобытность. Статус «самая красивая деревня» присваивается на пять лет. С поселением подписывается «хартия качества», соглашение, по которому ассоциация обязуется продвигать самые красивые деревни на российском и международном уровнях, а муниципалитеты обязуются соблюдать выдвинутые критерии. Совместно разрабатывается дорожная карта, способствующая повышению эстетического вида деревни и развитию инфраструктуры, активному вовлечению местного населения в развитие проекта. Значительное внимание уделяется сохранению историкокультурного наследия, туристско-информационным и гастрономическим аспектам.

Ассоциация является частью Федерации самых красивых уголков мира - это очень высокий статус, претендующий на вхождение в список наследия ЮНЕСКО [114]. С одной стороны, данный бренд способствует привлечению дополнительного внимания туристов, с другой стороны, он может влиять на восприятие идентичности у местных жителей и стать существенным стимулом для устойчивого развития. Сельское поселение может получать дополнительную прибыль за счет продажи местных сувениров, кулинарных блюд и турпродуктов.

В настоящий период на сайте ассоциации в путеводитель по самым красивым деревням входят 44 поселения России, из них 29 находятся на Русском Севере - 24 деревни Архангельской области, две карельские деревни, три малых поселения Вологодской области [112]. Большинство данных сельских поселений имеют статус «привала», критерии для включения в который не такие строгие, как для статуса «самая красивая деревня России». Многие исторические деревни труднодоступны, туда редко ходит общественный транспорт из-за плохих дорог, а добраться до некоторых можно только по воде на пароме или на внедорожнике (например, Кильца).

По поводу возможного членства в АСКДГР проводится опрос местных жителей на общем сходе, решение о вступлении в ассоциацию принимается большинством голосов. Некоторые сельские жители опасаются чрезмерного внимания гостей. Следует сохранять баланс между туризмом и традиционным укладом жизни. Так, в 2017 г. на местном сходе жители (в основном сезонные дачники) поморской онежской деревни Ворзогоры неожиданно отказались от членства в ассоциации. А жители карельской деревни Кинерма просили оградить их от назойливых туристов, нахлынувших в их маленькую деревню после вступления в ассоциацию. Местные жители объясняют это тем, что постоянно в Кинерме живет всего пять человек, а туристский поток в деревню вырос до 3 тыс. туристов в год [112], из-за чего не хватает местных кадров для проведения экскурсий и ресурсов для размещения многочисленных гостей. 
В Архангельской области в 2019 г. разработан новый туристский маршрут по трем самым северным красивым деревням Поморья (Кильца, Кимжа, Веркола) с проживанием гостей в лесном отеле «Голубино». Разработчики модульного маршрута планируют максимально задействовать в проекте местных жителей и дать импульс устойчивому развитию и сохранению сел [113]. Для того чтобы сельские территории развивались, проводить мастер-классы и устраивать программу для гостей должны местные жители. Тем самым они получат возможность заработать, что очень важно для сохранения деревень. При росте турпотока в самые красивые деревни происходит повышение активности местных сообществ, они оживают, жители начинают подавать заявки на различные гранты. В перспективе это становится выгодно и для соседних сельских поселений.

По итогам шестой экспедиции ассоциации на Русский Север в 2019 г. ещё несколько населенных пунктов Поморья могут претендовать на присвоение звания самой красивой деревни страны. В их числе отдаленные деревни Большие Нисогоры и Чуласа Лешуконского района, а также деревня Едомы Пинежского района [116].

Эксперты ассоциации отметили положительные изменения, произошедшие в четырех деревнях, уже вошедших в число самых красивых деревень России. Так, в Кимже при господдержке отремонтировали гостевой дом «Приют путника», в деревне Ошевенск на базе крестьянского дома создали ремесленную усадьбу, объединяющую местных мастеров для производства изделий народных промыслов. Ошевенск уже прочно вошла в перечень брендовых маршрутов России: там создан визит-центр, разработана программа «Ошевенская свадьба», организуются событийные мероприятия (рис. 44).

В Верколе планируется открытие нового гостевого дома, реконструируется Дом культуры, в феврале 2020 г. успешно проведены мероприятия, связанные со столетием писателя Фёдора Абрамова (рис. 45). В Кильце при поддержке французской Национальной федерации компаньонов восстановлен старинный колодец.

Архангельская область может стать первым российским регионом, где появятся деревни-спутники, или деревни-привалы. Интересен французский опыт задействования таких населённых пунктов, не подпадающих под критерии участника АСКДГР, но имеющих большой туристический потенциал. В Архангельской области одним из таких мест может стать село Ломоносово Холмогорского района.

В такие точки имеет смысл заехать по пути в самые красивые деревни, чтобы поесть, отдохнуть. Это поможет задействовать более широкий круг населённых пунктов. Такие привалы, помимо всего прочего, обеспечивают безопасность туристов во время путешествий [116].

Экспертам ассоциации следует также обратить внимание и на другие сельские поселения Русского Севера, сохранившие аутентичные памятники народного деревянного зодчества, самобытную культуру местных жителей и традиционную историческую среду обитания. Потенциальными кандидатами для вступления в АСКДГР являются: карельские (Панозеро, Хайколя, Шелтозеро, Шуерецкое), вологодские (Пожарище - национальную деревню Русского Севера посещает до 15 тыс. туристов в год, Горицы), архангельские (Вершинино, Сура, Дорогорское) деревни, старообрядческое село Усть-Цильма в Республике Коми, а также село Варзуга в Мурманской области (рис. 46). 


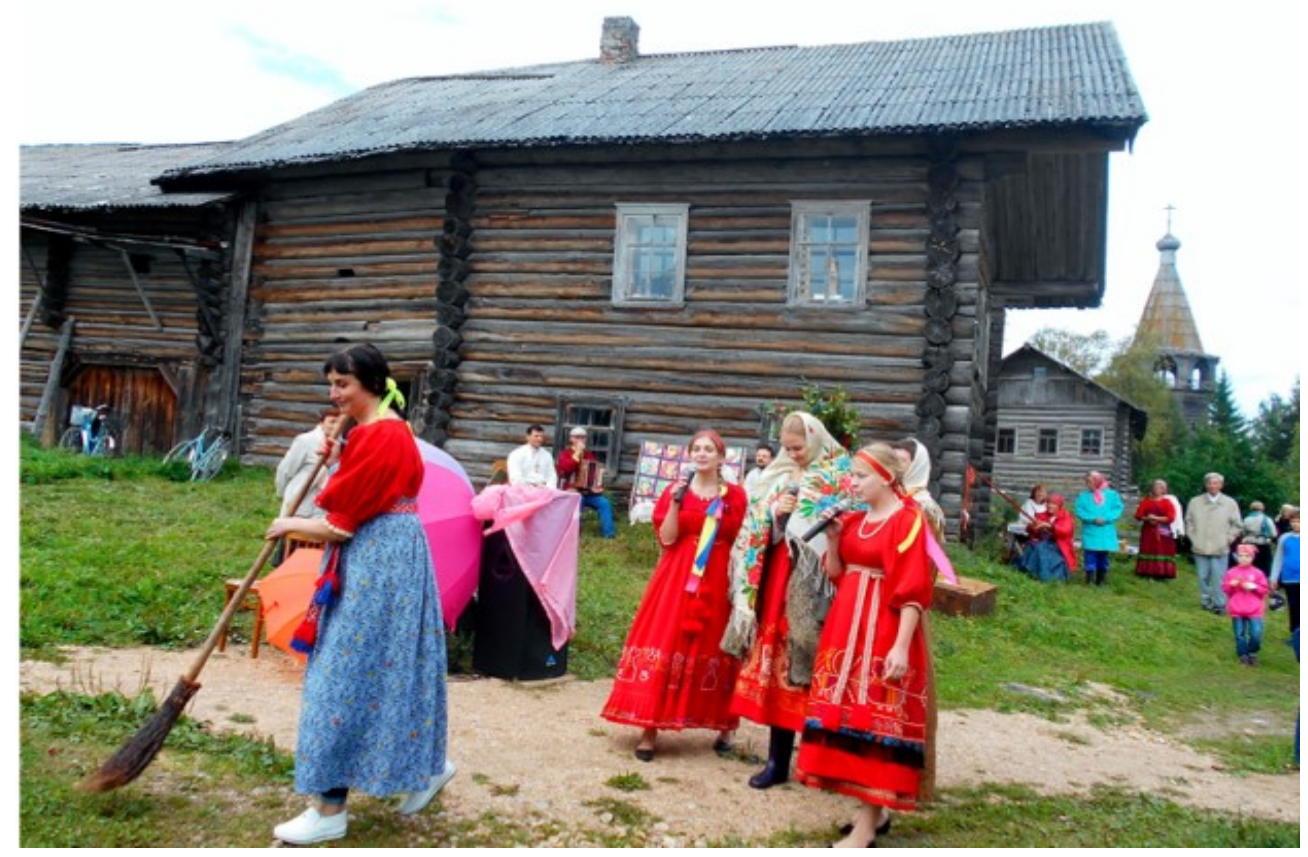

Рис. 44. Село Ошевенск

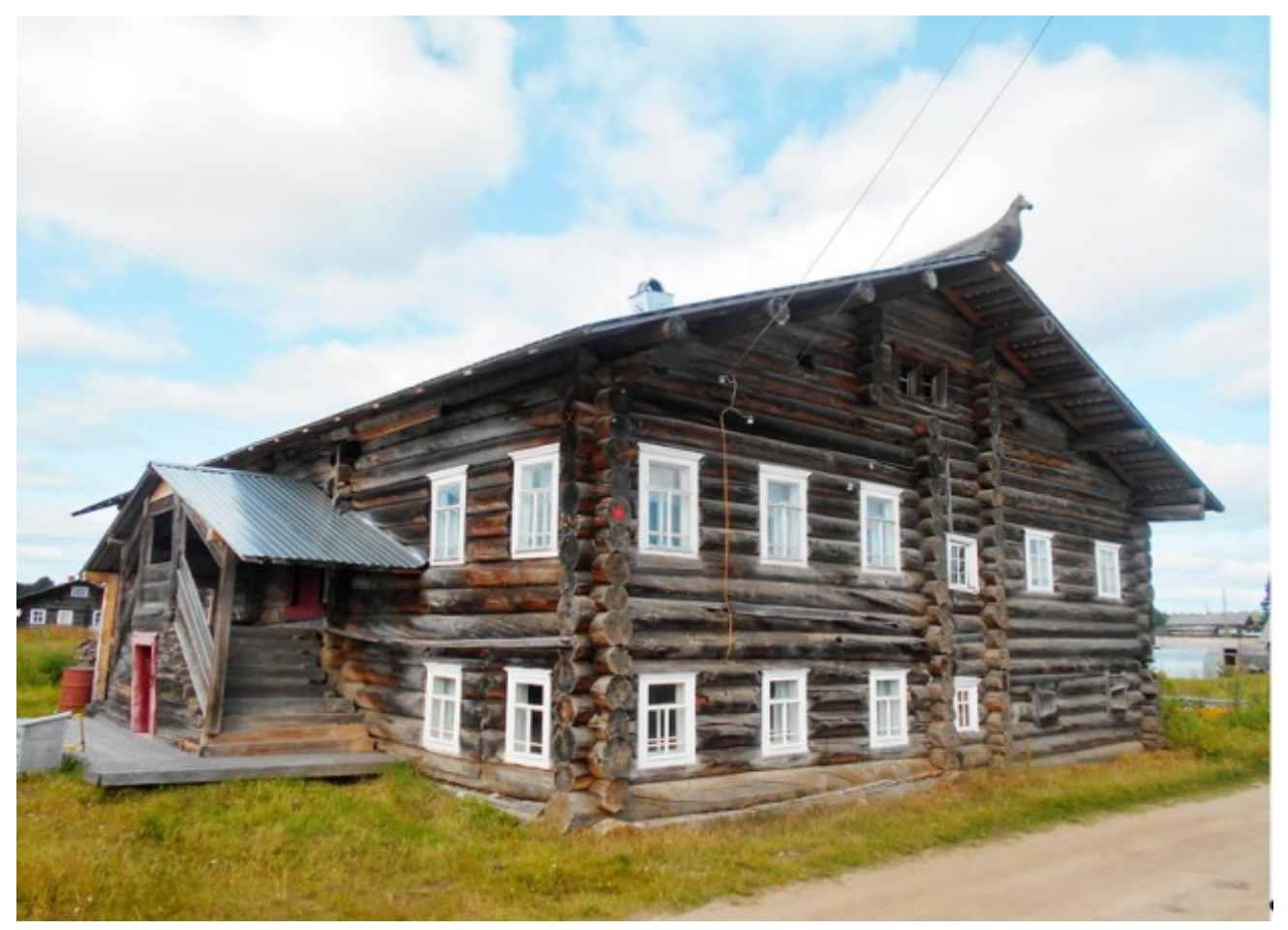

Рис. 45. Село Веркола - родина Федора Абрамова 


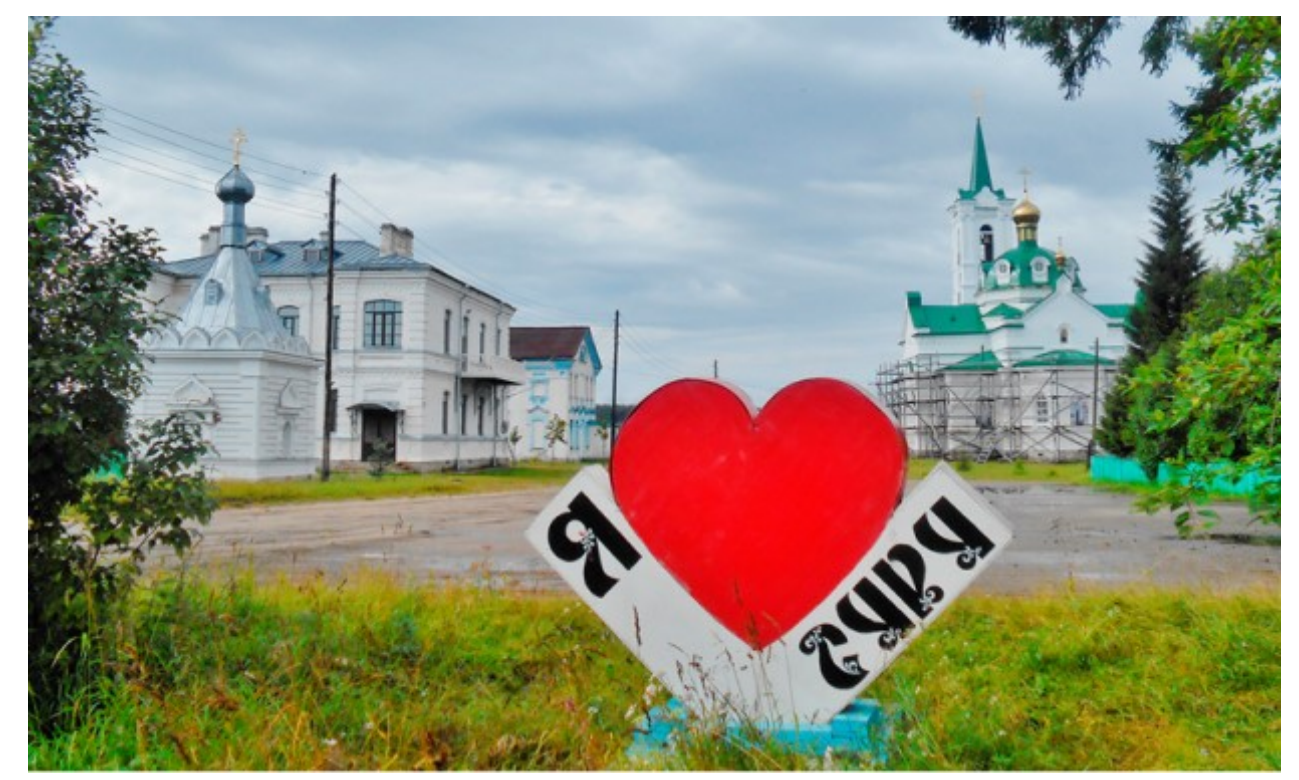

Рис. 46. Арт-объект в селе Сура, являющемся родиной Иоанна Кронштадтского

Одной из перспективных движущих сил устойчивого развития малых исторических поселений Русского Севера является территориальное общественное самоуправление (ТОC). Например, туристские проекты ТОС Архангельской области признаны одними из лучших в России (Кимжа, Яренск) [117].

В деревне Кимжа местным ТОС был разработан и реализован бренд «Самые северные мельницы в мире» с созданием музейной экспозиции. За время своей работы ТОС «Кимжа» реализовал более тридцати проектов, в том числе несколько международных.

В ТОС «Кимжа» сегодня сохранены народные ремесла: ткачество, гончарный промысел, валяние из шерсти. В то же время жители деревни Кимжа активно участвуют в реализации туристических инициатив TOC: индивидуальный предприниматель оказывает услуги по размещению в гостевом доме «Приют путника»; культурную программу с выступлением фольклорного ансамбля организуют в музее крестьянского быта «Политов дом», мезенское угощение ждет туристов в кафе с традиционной кухней «Кимженска паужна». Кроме того, представители ТОС «Кимжа» проводят экскурсии по территории деревни и обязательно ведут гостей к знаменитым мельницам. Небольшая северная деревня Кимжа реализует не по одному проекту в год, принимает зарубежных гостей, художников, научные экспедиции. В Кимже все проекты связаны в единое целое, результаты востребованы, есть видение целостности турпродукта [118].

Проект ТОС села Яренск участвовал в первом международном конкурсе «Туристский бренд: лучшие практики - 2015» в номинации «Лучший территориальный бренд в категории “Туристский бренд региона/муниципального образования"». По итогам конкурса проект «Яренск — родина Матушки Зимы» занял первое место.

Инициатива ТОС является важным инструментом, способным привлечь активное население к проектам, направленным на развитие туризма, сохранение 
культурно-исторического наследия, народных традиций и промыслов в малых городах и селах Русского Севера. В результате реализации локальных проектов ТОС на территории появляются объекты туристической инфраструктуры, которые могут стать началом серьезных туристических бизнес-проектов [117]. Важную роль в жизни ТОС играют местные общественники-энтузиасты из числа местных жителей, координирующие всю работу местных сообществ, например Татьяна Седунова (Пинежский район), Евдокия Репицкая, руководитель туристского культурно-музейного центра «Кимжа», Нина Николаевна Селиванова, организатор первого гостевого дома в Кимже, Надежда Калмыкова (село Кинерма). Благодаря этим людям с помощью развития туризма и социокультурной сферы возрождаются исторические деревни Русского Севера.

С целью сохранения традиционной исторической среды и культурных ландшафтов, уникальные сельские территории Русского Севера могут получить статус историко-культурного заповедника (например, Кимжа) или достопримечательного места регионального или федерального значения. Необходимо прежде всего сохранять баланс между туризмом и традиционным укладом жизни.

В сельских исторических поселениях Русского Севера в сфере гостеприимства целесообразно развивать систему частных гостевых домов с использованием в питании гостей самобытных местных кулинарных брендов.

\section{3. Проблемы сохранения историко-культурного наследия}

В настоящее время в России остро стоит проблема сохранения историкокультурного наследия, которое часто воспринимается властными структурами, профессиональным сообществом градостроителей и архитекторов серьёзным препятствием для развития городов. Тяжёлым обременением считаются исторические поселения и их границы, ставшие предметом жарких дискуссий. Руководство ряда исторических поселений пытается любыми путями избавиться от этого статуса или заменить федеральный статус поселения региональным. Такое стремление обусловлено возможностью решать все вопросы развития поселения на региональном уровне без вмешательства федеральных органов. Под развитием, как правило, подразумевается новое строительство в историческом центре, игнорирующее законодательство Российской Федерации в области сохранения наследия [119].

Настоящим брендом Русского Севера является народное деревянное зодчество. Здесь преобладают два типа традиционных деревянных жилых построек на Руси: русский (трехскатные крыши, часто с резными наличниками и светелкой) и угро-финский (северорусский, с двухскатными крышами). Как правило, в отдаленных деревнях сохранились наиболее аутентичные постройки. В отличие от памятников церковного зодчества, исторические сельские деревянные постройки в большинстве своем не имеют статуса объектов культурного наследия (ОКН). Также необходимо отметить недостаток информации об архитектурно-историческом наследии сельских поселений. В традиционных путеводителях по регионам Русского Севера широко представлены лишь самые известные памятники церковного зодчества и исторические города. 
Для сохранения наиболее ценных средовых зданий как в сельских поселениях, так и в городах необходимо пересмотреть региональные реестры ОКН (в основном в Вологодской, Архангельской областях и Республике Коми) и включить их в список вновь выявленных охраняемых ОКН. В Республике Карелия и Мурманской области практически все исторические здания ввиду их малочисленности имеют статус ОКН. Если здание не имеет статуса ОКН, внешний облик дома зачастую зависит от вкусов частных владельцев объекта, которые могут полностью изменить исторический облик здания. Если же дом признан ОКН и находится под защитой государства, то его владелец не имеет права ни на какие перестройки без согласования с соответствующими органами власти.

В крупных исторических городах России отмечается деградация городской среды, снос рядовой исторической застройки. Наши города теряют локальную идентичность и самобытность, уничтожается память места, связь поколений. На месте снесенных и сожженных зданий появляются многоэтажные «монстры», новоделы и торгово-развлекательные центры в стиле капиталистического романтизма (капрома) и евроремонта. Происходит разрыв целостной исторической ткани. Ценными и привлекательными являются не отдельные сохранившиеся дома-памятники, а целостная историческая среда, непрерывный архитектурный контекст места. Сохранение архитектурного наследия - это поддержка уникального облика городского ландшафта, его самобытности и идентичности.

Сейчас в России отсутствует культура сохранения и восстановления исторического наследия. В погоне за сиюминутным комфортом или прибылью в исторических зданиях вставляются металлические двери, пластиковые окна, сбивается лепнина и резной декор, фасады обшиваются дешевым сайдингом.

В любом старом европейском городе улицы с деревянными историческими зданиями становятся центром активной городской жизни, местом притяжения для туристов, малого бизнеса с привлечением денег в городской бюджет. Потенциал русских исторических городов явно недооценен. Таких красивых резных кружевных наличников, как в России, больше нет нигде в мире. В городах стран Западной Европы деревянный резной декор намного скромнее, чем в России. Деревянное народное зодчество - исконно русский стиль в архитектуре. Россия дала миру конструктивизм и русскую избу.

Отличительной особенностью русских исторических городов является целостная городская среда, сформированная деревянной застройкой второй половины XIX - начала XX столетий, которая демонстрирует национальную архитектуру, исчезающую в современной России. Деревянную архитектуру российских городов этого периода специалисты считают уникальным явлением мировой культуры и национальным достоянием России. Среди городов Русского Севера относительно целостная историческая среда сохранилась во всех пяти малых исторических городах, имеющих официальный статус исторического поселения федерального значения, а также в таких городах, как Устюжна, Вельск, Шенкурск и Сортавала. В крупных городах наиболее ценная деревянная застройка сохранилась фрагментарно в Вологде и Архангельске.

Важнейший принцип сохранения культурно-исторического наследия - без подлинности нет истории. Копии-новоделы, лишь имитирующие утраченные памятники, например в Вологде, не обладают ценностью. 
При этом Вологда входит в число трех городов России (наряду с Томском и Иркутском), где сохранилось уникальное деревянное зодчество во все своем стилевом разнообразии. Важно сберечь то немногое, что осталось в городе, используя положительный опыт реставрации и воссоздания таких зданий в Иркутске (Иркутская Слобода, или 130-й квартал) и Томске.

Чтобы спасти деревянную Вологду, градозащитники предлагают создать кластеры, где сохранилась деревянная застройка, и обозначить особый статус у этих территорий, который позволил бы застройщикам понимать, что здесь можно строить, привлекать малый бизнес, создавать условия для развития инфраструктуры туризма (рис. 47). Также необходимо запретить строить новоделы-муляжи на месте сожженных и снесенных подлинников, потому что иначе памятники будут сносить и поджигать до бесконечности. По мнению специалистов, необходима федеральная целевая программа, которая объединит исторические центры (Вологду, Архангельск, Иркутск и Томск). Сегодня признано, что сохранение архитектурного наследия имеет ценность не только для культуры, но и для экономики регионов, так оно повышает их инвестиционную и туристическую привлекательность [120].

Архангельск, где также происходит утрата рядовой деревянной застройки, спасает то, что в городе есть заповедная пешеходная улица - проспект Чумбарова-Лучинского, куда своевременно были перенесены образцы народного деревянного зодчества, ставшие популярным объектом показа для туристов (рис. 48,49$)$.

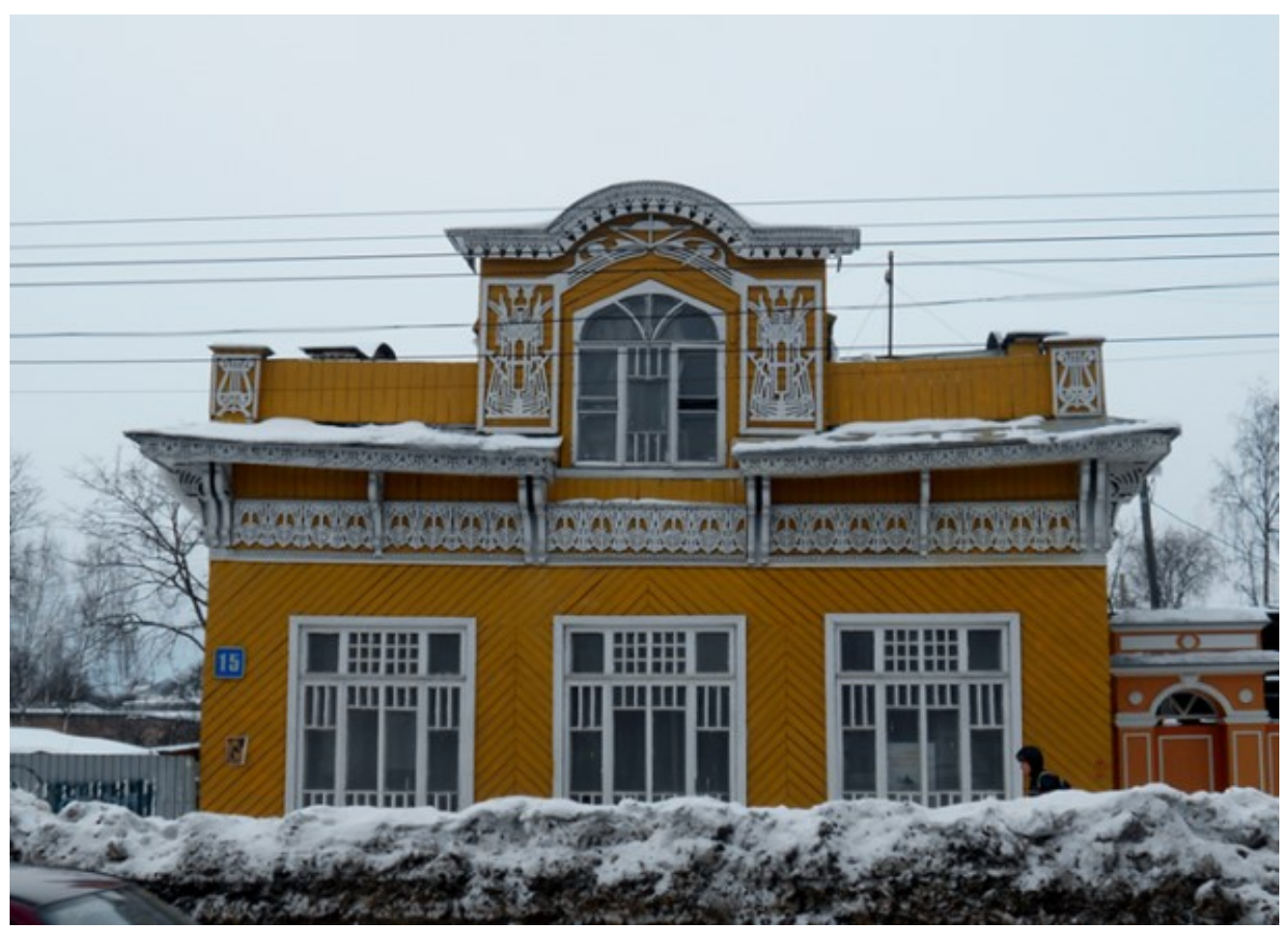

Рис. 47. Вологда. Деревянное зодчество 


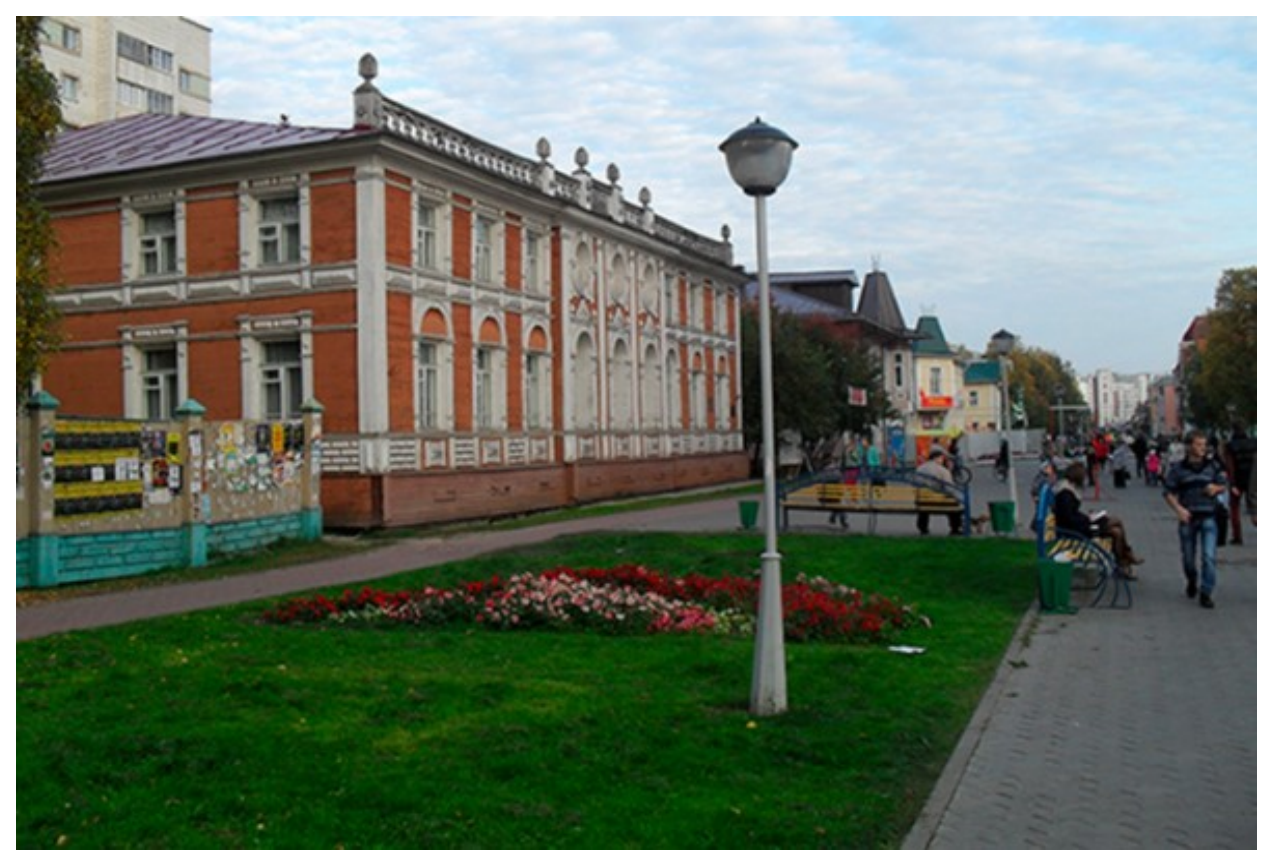

Рис. 48. Поморский Арбат (город Архангельск)

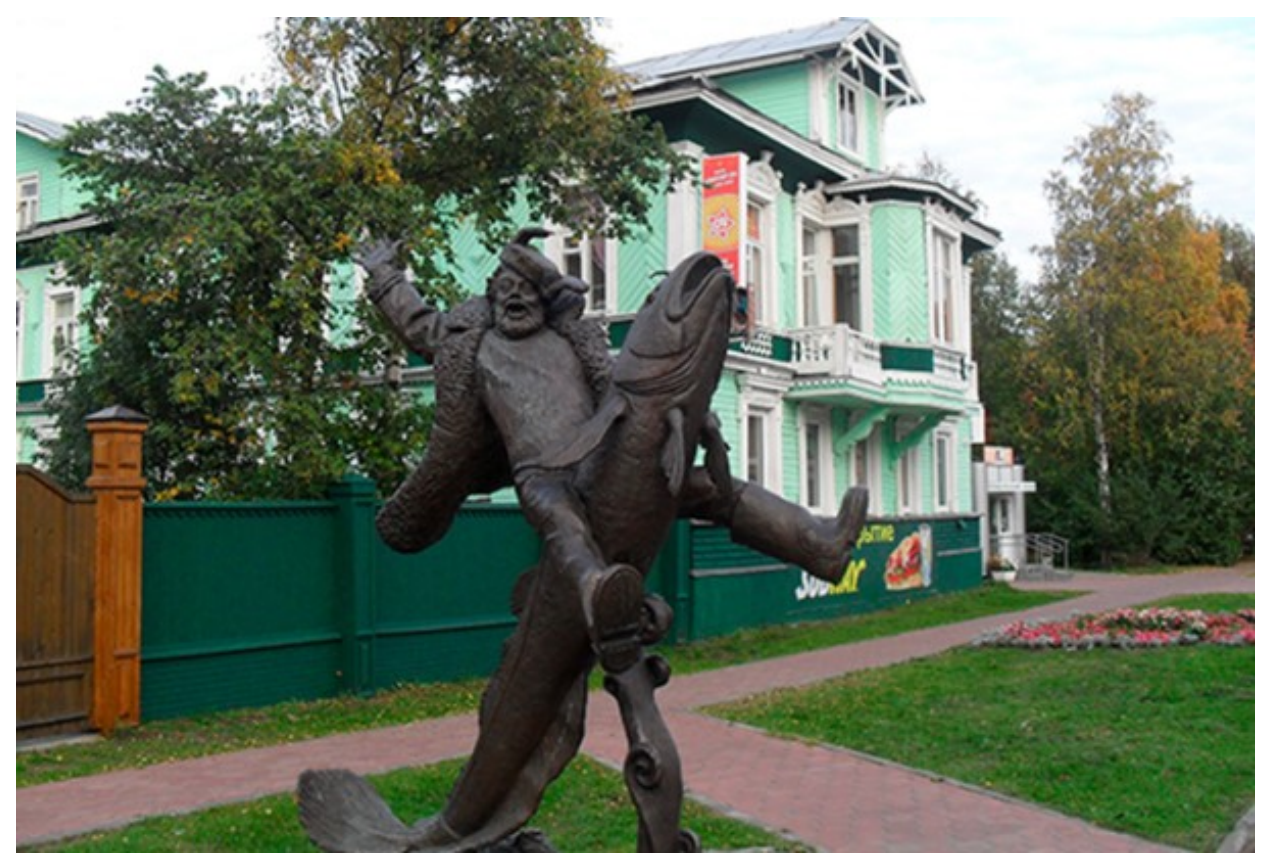

Рис. 49. Памятник Сене Малине (город Архангельск)

Чтобы сохранить оставшиеся дома-памятники и дать им новую жизнь, в старинных городах России проводится фестиваль «Том Сойер Фест» - общественный инициативный проект восстановления исторической городской среды силами волонтёров и спонсоров. «Том Сойер Фест» — это фестиваль для тех, кто хочет сделать город лучше, перейти от слов к делу, 
привести в порядок внешний вид города, обратить внимание на ценность исторической среды и объединить городских активистов в деятельное сообщество. Особое внимание уделяется восстановлению деревянных домов. Большинство объектов фестиваля - здания, не имеющие особого охранного статуса архитектурного памятника или исторического наследия. Идейным вдохновителем фестиваля стал самарский журналист Андрей Кочетков. Фестиваль был основан в Самаре в 2015 г. и с тех пор получил развитие по всей России. В 2019 г. «Том Сойер Фест» дошел и до Русского Севера. В Архангельске, Вологде и Тотьме были выбраны интересные деревянные здания для обновления и реставрации фасадов. Например, в Архангельске для реставрации был выбран известный памятник архитектуры - Марфин дом на пешеходной улице [121].

Для восстановления архитектурного наследия создан также фонд Ильи Варламова и Максима Каца «Внимание» (благотворительный фонд сохранения исторического наследия в России), который оказывает помощь в сборе финансовых средств, консультирует и помогает спасти от разрушения объекты культурного наследия нашей страны. Фонд создает модельную структуру, способную быстро и эффективно собирать средства и способствовать сохранению и восстановлению объектов. На Европейском Севере России фондом «Внимание» начат народный сбор средств на реставрацию деревянной ратуши в Сортавале, клуба в поселке Усть-Поча (Кенозерский национальный парк), деревянного храма Иоанна Богослова в деревне Анисимово Вологодской области [122].

Для сохранения ценного культурно-исторического наследия исторических городов и поселений Русского Севера необходимо расширить федеральный список исторических городов, включив в него старинные города и поселения, в которых сохранилась ценная и целостная историческая застройка. Исторические сельские поселения Русского Севера с нетронутым культурным ландшафтом и уникальными памятниками архитектуры могут получить статус историко-культурного заповедника либо достопримечательного места федерального или регионального значения.

Сохранение национальной идентичности, истории и культуры, материализованных в архитектуре исторических поселений Русского Севера, будет способствовать росту национального самосознания и любви к месту своего проживания, преемственности в формировании комфортной среды обитания, развитию внутреннего и въездного туризма.

6.3.1. Отечественный опыт развития сельского туризма в селе: Вятское как способ возрождения и сохранения культурно-исторического наследия

Наиболее ярким примером успешного развития сельского туризма в глубинке России является село Вятское Ярославской области. Предприниматель, ученый и меценат из Ярославля Олег Жаров поставил цель - создать механизмы социально-экономического развития уникальной сельской территории на основе возрождения культурно-исторического наследия. В качестве исследовательского полигона было выбрано депрессивное и «умирающее», но обладающее уникальнейшим культурно-историческим наследием село Вятское. В селе на одну тысячу населения сохранилось 114 исторических зданий, из них 53 памятника архитектуры (рис. 50) [60, с. 20]. 


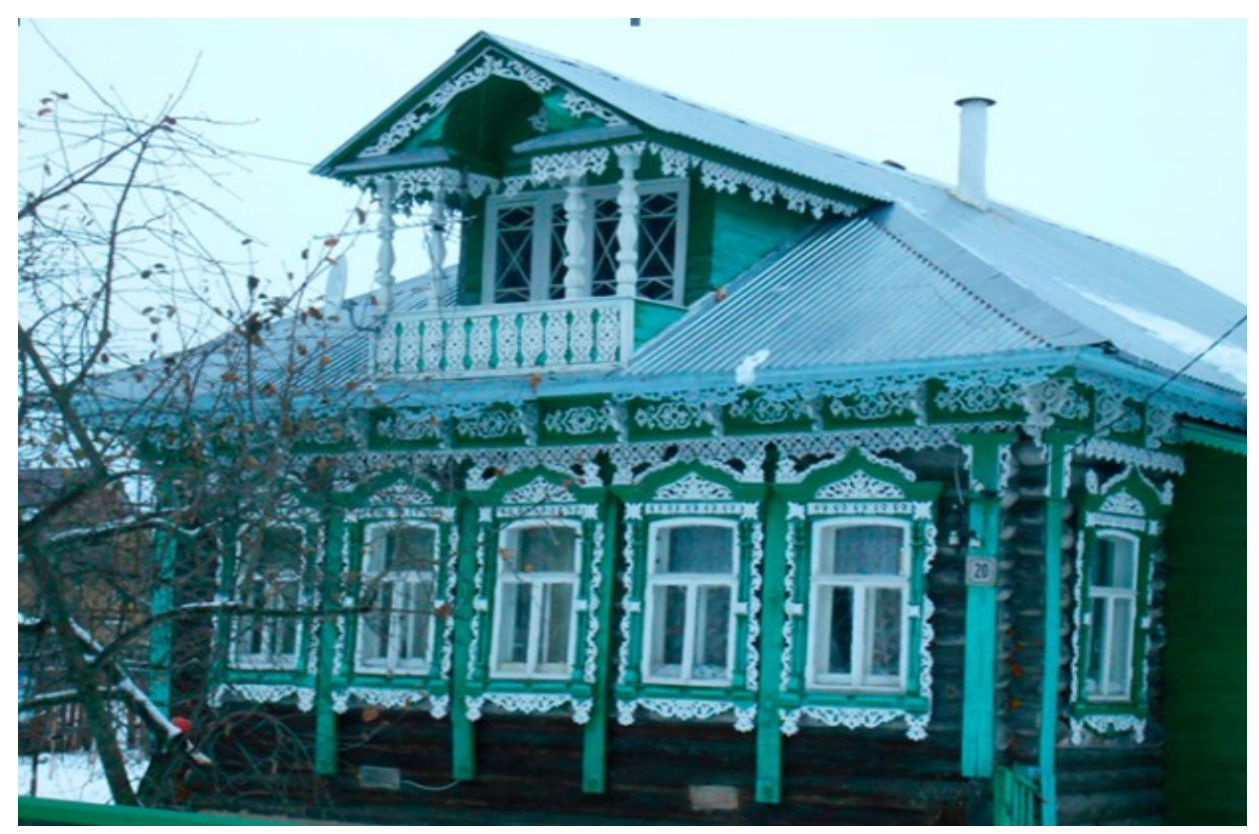

Рис. 50. Село Вятское

С 2007 г. ООО «Ярославская инвестиционно-финансовая компания» (руководитель Олег Жаров) реализуется программа реконструкции села с целью превращения его в музейно-туристический центр. В рамках программы ведутся работы по реконструкции зданий исторической части села, а также строительство новых сооружений и зданий. Олег Жаров стал покупать разрушенные купеческие дома, реставрировать их и продавать. В первую очередь позвал местных жителей на субботники, чтобы облагородить внешний облик и почистить территорию села от мусора. Провел канализацию, водопровод, открыл в отреставрированных зданиях гостиницу, ресторан, семь музеев (в том числе музей русской предприимчивости). Восстановлен православный храм, облагорожено два святых источника. Создан местный бренд «Вятское - огуречная страна».

В настоящий момент село Вятское - самое привлекательное и благоустроенное село Ярославской области, создана комфортная среда и инфраструктура для жизни и бизнеса, причем практически без помощи государства и привлечения бюджетных средств. В селе было отреставрировано 30 исторических зданий, построен новый коттеджный городок, в модернизацию инфраструктуры вложено 15 млн долларов частных инвестиций. Всего в Вятском создано 80 рабочих мест в сфере туризма и гостеприимства, из них 50 - для местных жителей. В результате туристический поток в село достиг 120 тыс. туристов в год [123, с. 3]. Предприниматель О. Жаров доказал, что сельский историко-культурный комплекс может быть рентабельным бизнесом, а возрождение культурного наследия финансово состоятельно.

В 2015 г. село стало первым членом АСКДГР. Количество мини-музеев в Вятском в последние годы увеличивается и в настоящее время достигло двенадцати. 


\section{ЗАКЛЮЧЕНИЕ}

Проведенное исследование, итогом которого является данная книга, позволяет сделать вывод, что туристская отрасль на Европейском Севере России находится в стадии активного развития. На данный момент актуально разработать конкурентоспособные инновационные туристские продукты и инвестиционные проекты. Туризм активно развивается во всех регионах Русского Севера, наблюдается ежегодный рост турпотока.

На основе экспертной оценки анализа современного состояния, основных проблем и перспектив развития туризма в регионах Европейского Севера России и западного сектора Российской Арктики исследованы экономико-географические и социокультурные аспекты устойчивого развития туристской отрасли. Сделан акцент на наиболее динамично развивающиеся направления и виды туризма. Особое внимание уделено проблемам развития арктического, экологического, международного, культурно-познавательного, событийного, круизного и сельского туризма в регионах. Среди новых трендов - гастрономический, промышленный, научный, социально-ответственный («волонтерские каникулы») туризм.

Туризм в северных регионах стремительно диверсифицируется, но в системе развития сферы гостеприимства для каждой территории необходима региональная стратегия качества сервиса, доступности не только базовых услуг, но и тех, которые повышают привлекательность поездки за счет событийных мероприятий, появления новых аттракций, туристскоинформационной навигации и повышения качества городской среды.

Показано, что на развитие туристской отрасли в 2020 г. существенное влияние оказала пандемия COVID-19. В настоящий период идет трансформация основных туристских направлений и перераспределение турпотоков. В пандемийный и постпандемийный периоды необходимо уделить особое внимание активным видам природного и экотуризма в немноголюдных местах, индивидуальным и семейным турам, автомобильному и велотуризму. Среди новых направлений северного туризма после снятия ограничений станут туры digital detox (время, проведенное вдали от интернета, компьютеров и телефонов) и плоггинг. Среди инновационных видов инфраструктуры экологического туризма на Русском Севере наиболее перспективны глэмпинги и экоотели, получившие широкое распространение в странах Северной Европы.

Выявлены основные факторы, способствующие инвестиционной и туристской привлекательности регионов Западной Арктики и Европейского Севера России: наличие уникальных объектов показа и качественной инфраструктуры, географическое положение и транспортная доступность, туристский потенциал и брендирование центров туризма, цена турпродукта и его рентабельность, рекламно-информационная известность региона, уровень безопасности для туристов, уровень господдержки для предпринимателей.

Обозначены основные проблемы развития туризма в Западной Арктике, обусловленные высокой стоимостью туристских и транспортных услуг, неразвитостью соответствующей инфраструктуры, отсутствием судов ледового класса, институциональными и природоохранными ограничениями. Ключевыми проблемами северного туризма являются также отсутствие качественных средств размещения, невысокий уровень сервиса, плохое состояние дорожно- 
транспортной сети, недостаток финансовых средств для создания новых объектов показа и реставрации памятников архитектуры, труднодоступность уникальных территорий и фактор сезонности.

Для реализации планов по развитию туризма на Русском Севере необходима масштабная модернизация и строительство туристской и транспортной инфраструктур. Недостаток объектов инфраструктуры и значительный их износ - главные препятствия для развития туризма.

Туризм - одно из перспективных направлений диверсификации хозяйственной деятельности в малых поселениях Севера. Наиболее экономически эффективно, конкурентоспособно и перспективно для развития уникальных туристско-рекреационных территорий Европейского Севера использование кластерного подхода. Инновационные инвестиционные проекты в сфере туризма должны увеличить туристский поток, что, в свою очередь, привлечет дополнительные инвестиции в модернизацию инфраструктуры и дальнейшее устойчивое развитие уникальных территорий, повысит качество жизни местного населения.

Специфическая проблема малых исторических городов Русского Севера состоит в значительной доле стареющего деревянного фонда ценной средовой застройки, утрата которой и соответствующее изменение городской исторической среды означают размывание идентичности поселения. Сфера культурно-исторического наследия - охрана памятников архитектуры и сохранение аутентичного облика - основная проблема малых городов с точки зрения культуры и туризма.

Сформулированы первоочередные стратегические задачи по развитию туризма: 1) повышение доступности уникальных арктических и северных территорий и отдаленных центров туризма для туристов с различным уровнем дохода; 2) организация региональных туристско-рекреационных кластеров на основе модернизации транспортной и туристской инфраструктур; 3) привлечение инвестиций в туристскую отрасль в виде частногосударственного партнерства; 4) стратегия глобального продвижения туристического потенциала Российской Арктики и Русского Севера; 5) развитие конкуренции в сфере транспорта, упрощение логистики, сочетание морских круизов с авиатуризмом позволят удешевить поездку для желающих посетить уникальные высокоширотные арктические территории и увеличить туристский поток; 6) минимизация антропогенного воздействия на природную среду Русского Севера; 7) сохранение объектов историко-культурного и природного наследия; 8) расширение списка исторических городов и поселений федерального значения, пересмотр и дополнение реестра объектов культурного наследия Европейского Севера; 9) в городах региона необходимо повышать уровень комфортности городской среды на основе развития дружелюбных общественных пространств и новых аттракций (пешеходных зон, набережных, велодорожек, музейных кварталов, уличных арт-объектов и муралов, креативных инсталляций, малой городской скульптуры) и туристскоинформационной навигации; 10) создание привлекательного образа локальной идентичности и брендирование центров туризма Европейского Севера. 


\section{ЛИТЕРАТУРА}

1. Карта распространения коронавируса в России и мире. URL: https://yandex.ru/web-maps/covid19?11=35.979154\%2C46.563817\&z=3.2 (дата обращения: 20.01.2021).

2. Национальный туристический портал. Регионы России // Новости. URL: https://russia.travel/ (дата обращения: 20.01.2021).

3. Иванова Е. Пошло - Поехало // Вечерний Мурманск. 2021. 15 янв. С. 18.

4. Попова А. В условиях пандемии сфера туризма проходит трансформацию. URL https://b-port.com/guests/225832 (дата обращения: 20.01.2021).

5. Смена туристского имиджа: Мурманская область. URL: https://travelvesti.ru/intervyu/smena-turistskogo-imidzha-murmanskayaoblast.html (дата обращения: 20.01.2021).

6. «"Русская Лапландия" развивает турбизнес. PБК+». URL: https://advis.ru/php/print news.php?id=16BD4D53-4FF0-7040-AC12F21BEBF7D620 (дата обращения: 20.01.2021).

7. Бертош А. Арктический туризм в условиях пандемии. URL: https://goarctic.ru/work/arkticheskiy-turizm-v-usloviyakh-pandemii/_ (дата обращения: 20.01.2021).

8. Арктический туризм в России / отв. редактор Ю. Ф. Лукин; сост. туристского справочника по регионам Н. К. Харлампьева; Сев. (Арктич.) федер. ун-т; Санкт-Петерб. гос. ун-т. Архангельск: САФУ, 2016. С. 96.

9. Лукин Ю. Ф. Арктический туризм: рейтинг регионов, возможности и угрозы // Арктика и Север. 2016. № 23. С. 116-122.

10. Эксперт: в Арктике необходимо создать мини-туркластеры в рамках ООПТ. URL: https://tass.ru/ekonomika/6316401 (дата обращения: 10.09.2020).

11. Бертош А. А. Арктический туризм: концептуальные черты и особенности // Труды Кольского научного центра РАН. 2019. Т. 10, № 7-17. С. 169-180.

12. Леонидова Е. Г. Развитие туризма в регионах Арктической зоны РФ // Север и Арктика в новой парадигме мирового развития. Лузинские чтения — 2016: мат-лы VIII междунар. науч.-практич. конф. (Апатиты, 14-16 апреля 2016 г.). Апатиты: ИЭП КНЦ РАН, 2016. С. 206-211.

13. Севастьянов Д. В. Рекреационное природопользование и туризм в планах нового освоения Севера России // Арктика и Север. 2018. № 30. С. 33.

14. Судостроители ставят на туристов. URL: http://www.rbc.ru/newspaper/2018/10/03/5bb346c49a79475b275d1aa0 (дата обращения: 10.09.2020).

15. Официальный сайт Министерства инвестиций, развития предпринимательства и рыбного хозяйства Мурманской области. URL: https://mirp.gov-murman.ru (дата обращения: 15.09.2020).

16. Официальный туристический портал Мурманской области // Новости // Архив. URL: http://www.murmantourism.ru/news/archive (дата обращения: 09.09.2020).

17. По информационным данным Комитета по туризму Мурманской области. URL: https://tourism.gov-murman.ru/news/ (дата обращения: 10.09.2020).

18. Норвежской круизной компании запретили проход через российскую Арктику. URL: https://tourism.interfax.ru/ru/news/articles/61930/ (дата обращения: 09.09.2020). 
19. Самофалова O. Арктика отпугивает туристов дикими ценами. URL: https://vz.ru/economy/2019/9/14/997668.html (дата обращения: 18.01.2020).

20. Сафронова И. Тимофей Рогожин: число российских туристов на Шпицбергене выросло за год втрое. URL: https://ratanews.ru/news/news_31102016_3.stm (дата обращения: 18.09.2020).

21. Баренцбург планирует уйти от грязного угля и стать воротами российского арктического туризма. URL: https://7x7-journal.ru/posts/2018/10/09/barencburgplaniruet-ujti-ot-gryaznogo-uglya-i-stat-vorotami-rossijskogo-arkticheskogoturizma (дата обращения: 18.09.2020).

22. Арктический экстрим. Из России пустят туры на архипелаг Шпицберген. URL: http://smartnews.ru/regions/murmansk/16151.html (дата обращения: 15.01.2020).

23. Сайт национального парка «Русская Арктика» // Новости; Туризм; Статистика. URL: http://www.rus-arc.ru/ru/Tourism/Statistics/ (дата обращения: 10.09.2020).

24. Рекордное число туристов посетило нацпарк «Русская Арктика» в 2019 году. URL: https://tass.ru/kultura/6936025 (дата обращения: 12.01.2020).

25. Сайт информационного агентства Арктик-Инфо // Туризм. URL: http://www.arctic-info.ru/news/turizm/ (дата обращения: 12.09.2020).

26. Отпуск на льдине. На Новой Земле построят первую гостиницу для туристов. URL: https://rg.ru/2019/10/22/reg-szfo/na-novoj-zemle-postroiatpervuiu-gostinicu-dlia-turistov.html (дата обращения: 12.01.2020).

27. Юсупов Т. Глава нацпарка «Русская Арктика» о туризме и летающих пингвинах. URL: https://lenta.ru/articles/2017/07/06/arctica/ (дата обращения: 20.09.2020).

28. Мастер-план для реализации проекта «Новый Мурманск» представят к маю 2021 года. URL: https://tass.ru/ekonomika/10048161 (дата обращения: 20.11.2020).

29. Новые пути Гипербореи // РГО. URL: https://www.rgo.ru/ru/article/novyeputi-giperborei (дата обращения: 07.02.2020).

30. Мурманская область вошла в ТОП-20 лидеров по въездному туризму. URL: https://mirp.gov-murman.ru/news/301966/ (дата обращения: 09.10.2020).

31. В Мурманске начал работу объединённый туристско-информационный центр // Информационное агентство «Би-порт». URL: https://bport.com/news/231280 (дата обращения: 09.10.2020).

32. Как приручить дикого туриста в Заполярье. URL: https://nordnews.ru/news/2019/09/05/?newsid=115305 (дата обращения: 09.10.2020).

33. Официальный сайт центра кластерного развития Мурманской области // Туристско-рекреационный кластер. URL: http://murmancluster.ru/turistskorekreacionnyy-klaster-murmanskoy-oblasti.html (дата обращения: 09.11.2020).

34. В Мурманской области появились новые туристические кластеры. URL: https://www.tv21.ru/news/2019/05/21/v-murmanskoy-oblasti-poyavilis-novyeturisticheskie-klastery (дата обращения: 09.11.2020).

35. Андреева Е. Ковдор в ожидании резидентов. URL: https://www.mvestnik.ru/sport/kovdor-v-ozhidanii-rezidentov/ (дата обращения: 09.10.2020).

36. Проект «Ковдор - столица Гипербореи» одержал победу в конкурсе «PRОбренд — 2020». URL: https://www.hibiny.com/news/archive/218748/ (дата обращения: 09.08.2020). 
37. Новый центр притяжения туристов появится в Заполярье. URL: https://severpost.ru/read/96585/ (дата обращения: 09.08.2020).

38. Отпуск на севере: Как и зачем в российской Арктике развивают туризм. URL: https://www.youtube.com/watch?v=_tqELO4e0rY (дата обращения: 09.02.2021).

39. Саляева Л. Терчане опасаются терниев в нацпарке // Мурманский вестник. 2019. 2 окт. С. 2.

40. Ищем баланс. В Кировске обсудили проект «Хибины для всех» и планы развития нацпарка «Хибины». URL: https://www.mvestnik.ru/eco/iwembalans/ (дата обращения: 10.02.2021).

41. Туризм на карантине. URL: https://severpost.ru/read/92923/ (дата обращения: 01.04.2020).

42. Чижова В. П. Рекреационные ландшафты: устойчивость, нормирование, управление. Смоленск: Ойкумена, 2011. 176 с.

43. Чижова В. П. Школа природы. Экологическое образование в охраняемых природных территориях. M.: Эколого-просветительский центр «Заповедники» - WWF, 1997. $128 \mathrm{c.}$

44. Сайт заповедника «Пасвик». URL: http://www.pasvik51.ru/index.php/ru/ (дата обращения: 12.11.2020).

45. Калинина Л. В. Лапландском заповеднике открыта новая экологическая тропа. URL: https://kn51.ru/news/society/ecology/2017/10/02/v-laplandskomzapovednike-otkryta-novaya-ekologicheskaya-tropa.html (дата обращения: 15.11.2020).

46. Сайт Лапландского природного заповедника. URL: http://www.laplandzap.ru (дата обращения: 22.11.2018).

47. Журналисты протестировали новый экомаршрут в Лапландском заповеднике. URL: https://www.murman.ru/news/2018/12/26/0749 (дата обращения: 15.11.2020).

48. Визит-центр под открытым небом откроется в Лапландском заповеднике. URL: https://tourism.interfax.ru/ru/news/articles/75122/ (дата обращения: 08.02.2021).

49. Кабыш 3. В радость и на пользу // Мурманский Вестник. 2018. 1 июня. С. 5.

50. Официальный сайт администрации Кандалакшского района // Туризм. Туристские тропы. URL: http://www.kandalakshaadmin.ru/index.php/index.php?option=com_content\&view $=$ article\&id $=9223 \# p$ 04 (дата обращения: 12.11.2020).

51. Эколого-краеведческая тропа «Старинная деревня Умба» откроется на юге Заполярья // Мурманский вестник. 2014. 13 окт.

52. Сайт музея наскального искусства «Петроглифы Канозера». URL: https://kanozero.murm.muzkult.ru (дата обращения: 16.11.2018).

53. Из Кандалакши в Колу. Это была первая в мире экологическая тропа. Не пора ли ее возродить? URL: https://www.mvestnik.ru/eco/iz-kandalakshi-vkolu/ (дата обращения: 08.02.2021).

54. Териберка из «Левиафана» вошла в Топ-20 туристических направлений года. URL: https://tass.ru/obschestvo/2734036 (дата обращения: 09.09.2020).

55. Коронавирус опустошил Териберку. URL: https://severpost.ru/read/91423/ (дата обращения: 09.03.2020).

56. «Арктический фестиваль - место не для слабаков». За 2 дня фестиваль в Териберке посетили 5000 человек. URL: https://www.tv21.ru/news/2019/07/15/arkticheskiy-festival-mesto-ne-dlya- 
slabakov-za-2-dnya-festival-v-teriberke-posetili-5000-chelovek обращения: 09.09.2020).

57. Стригин А. Поселкообразующая отрасль. URL: https://rg.ru/2019/06/25/regszfo/v-szfo-turizm-spasaet-ot-stagnacii-ekonomiku-nebolshih-dereven-igorodov.html (дата обращения: 09.09.2020).

58. Приказ Министерства развития промышленности и предпринимательства Мурманской области № 164-ОД от 30 ноября 2018 г. «Об утверждении мастер-плана развития с. п. Териберка Кольского района и программы его реализации».

URL: http://murmantourism.ru/uploads/media/default/0001/02/803e17c9ae3f63cdb9b 40489dd67aaab663f81bb.pdf (дата обращения: 09.09.2020).

59. Создание природного парка в Териберке не исключит проведение там фестивалей. URL: https://tourism.interfax.ru/ru/news/articles/70996/ (дата обращения: 09.08.2020).

60. Грушенко Э. Б., Васильев А. М. Туризм на Европейском Севере России и в Западной Арктике. Апатиты: КНЦ РАН, 2013. 90 с.

61. Хотенов А. В. 500 мест Русского Севера, которые нужно увидеть. М.: Мартин, 2013. С. 3-4.

62. Кусков А. С. Культурные ландшафты как ресурс туристского развития Русского Севера // Опыт сохранения историко-культурного наследия и трансграничное сотрудничество в сфере культурного туризма: мат-лы междунар. науч.-практич. конф. (Витебск, 24-25 октября 2012 г.). Витебск: УО «ВГУ им. П. И. Машерова», 2012. С. 164-169.

63. Межрегиональные направления в рамках историко-культурного и туристского проекта «Серебряное ожерелье России». URL: http://tourism.pskov.ru/tourist_routes/sor (дата обращения: 10.09.2020).

64. Карелия: эпическая туристская программа «Калевала»: сб. докл. и тез. сообщ. междунар. науч.-практич. конф. (Республика Карелия, Петрозаводск, 20-21 ноября 2002 г.). М.: РИБ «Турист», 2002. С. 59-86.

65. Гастрономическая карта России. URL: https://azgaz.ru/gazworld/news/russian-gastronomic-map/ (дата обращения: 10.09.2020).

66. Официальный интернет-портал Республики Карелия // Новости // Туризм. URL: http://gov.karelia.ru/news/?tags=15 (дата обращения: 18.09.2020).

67. Инвестиционный портал Республики Карелия // Туризм. URL: http://kareliainvest.ru/republicforinvestors/projects/turizm/ (дата обращения: 18.09.2020).

68. Унифицированный туристский паспорт Республики Карелия. URL: https://ar.investinrussia.com/data/image/regions/unif-turpass2016.pdf (дата обращения: 18.09.2020).

69. Сортавала ждет в 3 раза больше туристов в 2019 году благодаря Ласточке. URL: $\quad$ https://karelinform.ru/news/culture/12-02-2019/sortavala-zhdet-v-3-razabolshe-turistov-v-2019-godu-blagodarya-lastochkel (дата обращения: 09.09.2020).

70. Отдел развития туризма министерства культуры Архангельской области. Анализ экономических и статистических показателей в сфере туризма Архангельской области в 2018 году. URL: http://pomorland.pro/informatsionno-analiticheskie/analiz-ekonomicheskikh-istatisticheskikh-pokazateley-v-sfere-turizma-arkhangelskoy-oblasti-v-2018-g/ (дата обращения: 10.09.2020). 
71. Интерес к отдыху на Русском Севере растет. URL: http://www.pomorland.travel/news/interes_k_otdykhu_na_russkom_severe_rastet/ (дата обращения: 10.03.2020).

72. Открытый Север: Туристский портал Архангельской области // Новости. URL: http://www.pomorland.travel/news/ (дата обращения: 10.09.2020).

73. Каргополь, Котлас, Архангельск, Устьяны - точки роста турпотока в Архангельскую область. URL: http://dvinanews.ru/-b89vt8yd (дата обращения: 10.09.2020).

74. Лучшие практики развития сельского туризма на территории Архангельской области: информац.-методич. сб. Архангельск, 2016. С. 38-43.

75. Архангельская область вошла в федеральные сборники лучших практик туризма. URL: http://dvinanews.ru/-p8z1018g (дата обращения: 10.02.2020).

76. Соловецкий центр гостеприимства. URL: https://culttourism.ru/arkhangelskaya/solovki/solovetskie_ostrova_solovetskiy_t sentr_gostepriimstva.html (дата обращения: 29.09.2020).

77. Соловецкий государственный историко-архитектурный и природный музейзаповедник. URL: http://www.solovky.ru/ (дата обращения: 26.09.2020).

78. Рост турпотока на Соловки до 20 тыс. человек ожидается летом 2018 года. URL: https://tass.ru/v-strane/5200108 (дата обращения: 28.09.2020).

79. Соловки инфо: Соловецкий информационный портал. URL: http://www.solovki.info (дата обращения: 28.09.2020).

80. Туристический информационный центр «Соловки». URL: http://www.nasolovki.ru (дата обращения: 27.09.2020).

81. Независимые гиды: Один день на Соловках. URL: http://inguide.ru (дата обращения: 29.09.2020).

82. Не надо превращать Соловки в поле подозрений и раздора. URL: http://www.pravoslavie.ru/88187.html (дата обращения: 25.09.2020).

83. Сайт Соловецкого Спасо-Преображенского монастыря. URL: http://solovki-monastyr.ru (дата обращения: 28.09.2018).

84. Официальный портал Правительства Вологодской области // О регионе // Туризм. URL: https://vologda-oblast.ru/o_regione/turizm/ (дата обращения: 18.02.2020).

85. Туристско-информационный центр Вологодской области: Открой для себя Вологодскую область! URL: https://vologdatourinfo.ru/obschaya-informaciya (дата обращения: 18.02.2020).

86. Сайт Департамента культуры и туризма Вологодской области // Ведомственная информация // Новости. URL: https://depcult.gov35.ru/vedomstvennaya-informatsiya/novosti/_ (дата обращения: 18.02.2020).

87. Итоги развития сферы туризма в 2019 года на территории Вологодской области. URL: https://depcult.gov35.ru/vedomstvennayainformatsiya/novosti/5/135357/ (дата обращения: 10.03.2020).

88. Вологодская область. Туризм в цифрах. URL: https://nbcrs.org/regions/vologodskaya-oblast/statistics/ (дата обращения: 18.02.2020).

89. На 9 тыс. «круизных» туристов больше приняла Вологодская область в 2019 году. URL: https://travel.rambler.ru/news/43074000-na-9-tys-kruiznyh-turistovbolshe-prinyala-vologodskaya-oblast-v-2019-godu/ (дата обращения: 18.02.2020). 
90. Ландшафтно-архитектурная среда Белозерья. URL: https://www.booksite.ru/fulltext/belo/zerje/9.htm (дата обращения: 20.01.2020).

91. Белозерск превратят в летнюю туристическую столицу. URL: http://www.tourbus.ru/news/5451.html (дата обращения: 21.01.2020).

92. Гришина С. Былинный город на Белом озере. URL: http://cultinfo.ru/journal/summer-2016/bylinnyy-gorod-na-belom-ozere/ (дата обращения: 22.01.2020).

93. В Белозерске построят причал для приема теплоходов. URL: https://www.krassever.ru/article/v-belozerske-postroyat-prichal-dlyateplokhodov (дата обращения: 20.01.2020).

94. Парфенова Н. Турпоток в Великий Устюг за 20 лет вырос в сто раз. URL: https://ratanews.ru/news/handler.aspx?id_number=10311\&sort_ord=2\&id_lang uage $=1$ (дата обращения: 10.09.2020).

95. Мягкова Е. Что нужно Великому Устюгу для роста турпотока. URL: https://www.atorus.ru/news/press-centre/new/40120.html (дата обращения: 10.09.2020).

96. Ростуризм ожидает, что турпоток в Великий Устюг вырастет в два раза в ближайшее время. URL: https://tass.ru/obschestvo/4741154 (дата обращения: 10.09.2020).

97. Фактически музей занял нишу антикафе: интервью с Алексеем Новосёловым. URL: http://cultmosaic.ru/press-center/contest/fakticheskimuzey-zanyal-nishu-antikafe-intervyu-s-alekseem-novosyelovym/ (дата обращения: 20.10.2020).

98. Туристско-информационный сайт Тотемского района. URL: http://tourizmtotma.ru (дата обращения: 25.10.2020).

99. Тотьма от А до Я, или азбука тотемской идентичности. URL: http://tourizm-totma.ru/totma-ot-a-do-ya-ili-azbuka-totemskoj-identichnosti (дата обращения: 23.10.2020).

100. Тотемский туризм: от А до Я. URL: http://tourizm-totma.ru/news/3330.html (дата обращения: 20.10.2020).

101. Грушенко Э. Б. Феномен туристского развития малого исторического города на Русском Севере // Мозаика городских пространств: экономические, социальные, культурные и экологические процессы: сб. мат-лов всерос. науч. конф. (Москва, МГУ, 27-29 ноября 2015 г.). М.: Геогр. ф-т МГУ, 2016. С. 165-169.

102. Официальный сайт администрации Тотемского района // Туризм. URL: http://totma-region.ru/news/turizm (дата обращения: 07.02.2020).

103. Почему Тотьма такая неправильная. Интервью с директором Тотемского музейного объединения Алексеем Новосёловым. URL: https://rusbestrailways.ru/ru/article/pochemu-totma-takaya-nepravilnaya (дата обращения: 07.02.2020).

104. Туристский портал Вологодской области. URL: http://vologdatourinfo.ru/ (дата обращения: 20.10.2020).

105. В Тотьме откроется маршрут по объектам древнего соляного промысла. URL: https://rusbestrailways.ru/ru/article/pochemu-totma-takaya-nepravilnaya (дата обращения: 07.12.2020).

106. Грушенко Э. Б. Основные тенденции развития туризма в исторических городах Русского Севера // Интеграция туризма в экономическую систему региона: перспективы и барьеры: мат-лы I междунар. науч.-практич. конф. 
(Орёл, 25-26 апреля 2019 г.): в 2 ч. Ч. 1. Орёл: ОГУ им. И. С. Тургенева, 2019. C. 206-211.

107. Не менее 2 млрд. рублей инвестируют туристы в экономику Вологды за один год. URL: https://вологда.pф/news/tourism/37501/ (дата обращения: 18.01.2020).

108. Каргополь - родина президента Русской Америки. URL: https://www.pomorland.travel/news/kargopol_rodina_prezidenta_russkoy_amer iki/?special_version=Y (дата обращения: 18.01.2020).

109. Проблемы малого города Русского Севера: есть ли выход? URL: http://rusregions.com/problemy-malogo-goroda-russkogo-severa-yest-livykhod/ (дата обращения: 18.01.2020).

110. Как развивать малые города? Интервью с Игорем Задориным. URL: https://fomlabs.ru/material/kak-razvivat-malye-goroda (дата обращения: 18.01.2020).

111. Гершман

A. Тактический

урбанизм.

URL: https://gre4ark.livejournal.com/223375.html (дата обращения: 18.01.2020).

112. Ассоциация самых красивых деревень и городков России // Деревни // Новости. URL: https://krasaderevni.ru/villages/ (дата обращения: 10.09.2020).

113. Красоту спасёт бренд: в Архангельской области тестируют маршрут по удалённым деревням. URL: https://bclass.ru/stil-zhizni/turizm/krasotuspasyet-brend-v-arkhangelskoy-oblasti-testiruyut-marshrut-po-udalyennymderevnyam/ (дата обращения: 10.09.2020).

114. Ассоциация самых красивых деревень и городков России // Ассоциация. URL: https://krasaderevni.ru/association/ (дата обращения: 10.09.2020).

115. Карелия: Туристский портал // Кинерма. URL: http://www.ticrk.ru/regions/region/settlement/?PID=7515\&ID=8172 （дата обращения: 10.09.2020).

116. В регионе появится новый турмаршрут по самым красивым деревням Поморья. URL: http://dvinanews.ru/-mx2ggcxv (дата обращения: 10.09.2020).

117. Интернет-портал территориального общественного самоуправления Архангельской области. URL: https://www.tos29.ru (дата обращения: 10.09.2020).

118. ТОС как движущая сила развития сельских территорий. URL: http://www.kenozero.ru/mestnym-zhitelyam/mestnym-zhitelyam/vozmozhnostidlya-razvitiya/tos-kak-dvizhushchaya-sila-razvitiya-selskikhterritoriy/?sphrase id=34768 (дата обращения: 10.09.2020).

119. Романова Л. С. Историко-культурное наследие и развитие исторического поселения город Томск. URL: https://cyberleninka.ru/article/n/istorikokulturnoe-nasledie-i-razvitie-istoricheskogo-poseleniya-gorod-tomsk/viewer (дата обращения: 18.03.2020).

120. В Вологде на грани исчезновения знаменитые памятники архитектуры деревянного зодчества. URL: https://tvkultura.ru/article/show/article_id/4735/ (дата обращения: 18.03.2020).

121. Том Сойер Фест в твоем городе. URL: http://tsfest.ru/ (дата обращения: 18.03.2020).

122. Фонд сохранения исторического наследия Ильи Варламова «Внимание». URL: https://fondvnimanie.ru/about (дата обращения: 18.03.2020).

123. Деньги потекут... из села // Аргументы и Факты. 2012. 25 июня. С. 3. 
ИНСТИТУТ ЭКОНОМИЧЕСКИХ ПРОБЛЕМ ИМ. Г.П. ЛУЗИНА -

ОБОСОБЛЕННОЕ ПОДРАЗДЕЛЕНИЕ ФГБУН

ФЕДЕРАЛЬНОГО ИССЛЕДОВАТЕЛЬСКОГО ЦЕНТРА

«КОЛЬСКИЙ НАУЧНЫЙ ЦЕНТР РОССИЙСКОЙ АКАДЕМИИ НАУК»

РОССИЯ, 184209, Мурманская область, г.Апатиты, ул.Ферсмана, 24а
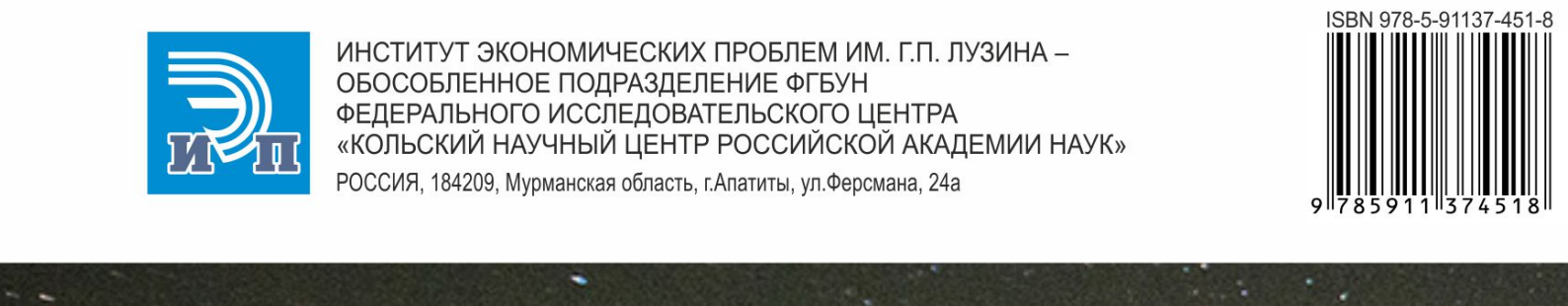

$$
\text { 䀊 }
$$

